Editoras

Rosario Puertas-Hidalgo

Mónica Abendaño

Cesibel Valdiviezo-Abad

\author{
Prólogo
}

Yanyn Rincón Quintero

\title{
Comunicar: de la táctica a la estrategia
}

Cuadernos Artesanos de Comunicación / 178

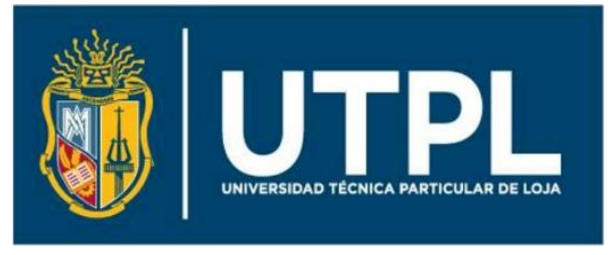




\section{Cuadernos Artesanos de Comunicación \\ Coordinador editorial: José Manuel de Pablos - jpablos@ull.edu.es \\ Comité Científico \\ Presidencia: José Luis Piñuel Raigada (UCM) \\ Secretaría: Milena Trenta}

- José Miguel Túñez (Universidad de Santiago, USC)

- Victoria Tur (Universidad de Alicante, UA)

- Miguel Vicente (Universidad de Valladolid, UVA)

- Ramón Zallo (Universidad del País Vasco, UPV-EHU)

- Núria Almiron (Universidad Pompeu Fabra, UPF)

- Francisco Campos Freire (Universidad de Santiago de Compostela)

- José Cisneros (Benemérita Universidad Autónoma de Puebla, BUAP)

- Bernardo Díaz Nosty (Universidad de Málaga, UMA)

- Carlos Elías (Universidad Carlos III de Madrid, UC3M)

- Paulina B. Emanuelli (Universidad Nacional de Córdoba, UNC)

- José Luis González Esteban (Universitas Miguel Hernández de Elche, UMH)

- Marisa Humanes (Universidad Rey Juan Carlos, URJC)

- Juan José Igartua (Universidad de Salamanca, USAL)

- Xosé López (Universidad de Santiago de Compostela)

- Maricela López-Ornelas (Universidad Autónoma de Baja California, UABC)

- Octavio Islas (Universidad de los Hemisferios, Ecuador)

- Javier Marzal (Universidad Jaume I, UJI)

- José Antonio Meyer (Benemérita Universidad Autónoma de Puebla, BUAP)

- Ramón Reig (Universidad de Sevilla, US)

- Miquel Rodrigo Alsina (Universidad Pompeu Fabra, UPF)

- Xosé Soengas (Universidad de Santiago de Compostela)

- José Luis Terrón (Universidad Autónoma de Barcelona, UAB)

\footnotetext{
* Queda expresamente autorizada la reproducción total o parcial de los textos publicados en este libro, en cualquier formato o soporte imaginables, salvo por explícita voluntad en contra del autor o autora o en caso de ediciones con ánimo de lucro. Las publicaciones donde se incluyan textos de esta publicación serán ediciones no comerciales y han de estar igualmente acogidas a Creative Commons. Harán constar esta licencia y el carácter no venal de la publicación.
}

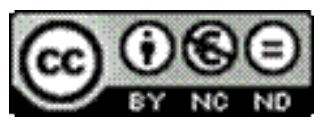

Este libro y cada uno de los capítulos que contiene (en su caso), así como las imágenes incluidas, si no se indica lo contrario, se encuentran bajo una Licencia Creative Commons Atribución-No Comercial-Sin Derivadas 3.0 Unported. Puede ver una copia de esta licencia en http://creativecommons.org/licenses/by-nc-nd/3.0/ Esto significa que Ud. es libre de reproducir y distribuir esta obra, siempre que cite la autoría, que no se use con fines comerciales o lucrativos y que no haga ninguna obra derivada. Si quiere hacer alguna de las cosas que aparecen como no permitidas, contacte con los coordinadores del libro o con el autor del capítulo correspondiente.

* La responsabilidad de cada texto es de su autor o autora. 
Rosario Puertas-Hidalgo, Mónica Abendaño, y Cesibel Valdiviezo-Abad/Editores

Prólogo Yanyn Rincón Quintero

\section{Comunicar: de la táctica a la estrategia}

YANYN RinCÓN QUiNTERO, PATRICIA COLL RUBio, JOSEP LLUíS Micó, LeLIa ZAPATA, MÓNICA ABENDAÑo, LAURA SÁNCHEZ, Rosario PuERTAS-HidAlgo, CESIBEL VALDIVIEZO-ABAD, Gustavo Cusot, Isabel Palacios, VAnessa Karina DuQue RENGEL, ULIANOVA ELIZABETH ESPINOSA JIMÉNEZ, NANCY Estella VesGa, STEFANI DEL CISNE PALADINES CARRANZA, JENNY JOVITA YAGUACHE QUICHIMBO.

Cuadernos Artesanos de Comunicación /178

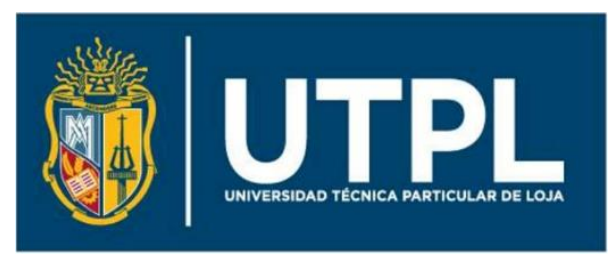


CAC 178 - Comunicar: de la táctica a la estrategia

Rosario Puertas-Hidalgo, Mónica Abendaño y Cesibel ValdiviezoAbad (Editores)

| Precio social: 7,50€ | Precio en librería. 9,75€ |

Editores: Milena Trenta y Alberto Ardèvol

Diseño: F. Drago

Ilustración de portada: Fragmento del cuadro Casillero de E. Álvarez.

Imprime y distribuye: F. Drago. Andocopias S. L.

c/ La Hornera, 41. La Laguna. Tenerife.

Teléfono: 922250554 | fotocopiasdrago@,telefonica.net

Edita: Sociedad Latina de Comunicación Social - edición no venal - La Laguna (Tenerife), 2020 - Creative Commons

http://www.revistalatinacs.org/14SLCS/portada2014.html

Descargar en pdf:

http://www.cuadernosartesanos.org/\#178

Protocolo de envío de manuscritos:

http://www.cuadernosartesanos.org/protocolo.html

ISBN - 13: 978-84-17314-35-4

DL: TF-193-2020

DOI: $10.4185 / \operatorname{cac} 178$ 


\section{Comunicar: de la táctica a la estrategia \\ Rosario Puertas-Hidalgo, Mónica Abendaño y Cesibel \\ Valdiviezo-Abad (Editores)}

\section{Resumen}

En la planificación de la comunicación se deben definir los objetivos que se quieren alcanzar, las estrategias que permitirán alcanzarlos, el público o los públicos internos o externos y los canales idóneos para llegar a ellos. Es importante evitar el ejecutar acciones o tácticas de comunicación sin una estrategia definida ni un plan de trabajo claro.

El conocer a los consumidores, para comprender sus necesidades y responder a ellas eficientemente, es fundamental a la hora de planificar. Internet se ha transformado en una herramienta para comunicarnos, entretenernos e informarnos. Esto ha modificado los patrones de consumo e información, generando nuevos canales de difusión, información y comercialización.

Google asegura que el $84 \%$ de los usuarios basan sus decisiones de compra en las recomendaciones de su círculo social. Por ello, la presencial en las diversas plataformas digitales busca generar un vínculo entre las marcas y los usuarios, por lo que, los contenidos deben ser humanos y cercanos.

Además, la evaluación de las estrategias y tácticas de comunicación permite optimizar y maximizar el impacto, conocer cuánta ganancia efectiva se ha logrado.

Palabras claves: comunicación estratégica, comunicación integral, planificación de comunicación, plataformas digitales.

\section{Forma de citar este libro}

Puertas-Hidalgo, R., Abendaño, M. \& Valdiviezo-Abad, C. (Eds.), (2020). Comunicar: de la táctica a la estrategia. Cuadernos Artesanos de Comunicación, nº178. La Laguna (Tenerife) 


\section{Índice}

Prólogo

Yanyn Rincón Quinteros..

1. Planificación estratégica de la comunicación digital

Patricia Coll, Josep Lluís Micó..

2. El plan estratégico de comunicación interna, herramienta para alinear al personal

Lelia Zapata

3. De la comunicación interna al diálogo organizacional

Laura Sánchez, Mónica Abendaño.

4. Transformación digital frente al rol del comunicador interno

Rosario Puertas-Hidalgo, Cesibel V aldiviezo-Abad.

5. Uso estratégico de medios digitales aplicado a la comunicación interna: Caso Cocoa

Gustavo Cusot, Isabel Palacios

6. Construcción de imagen y reputación digital

Vanessa Duque, Ulionova Espinosa.

7. Inbound marketing: de la confianza a la venta.

Nancy Estella Vesga.

8. Confianza y reputación en tiempos de infoxicación

Stefeni Paladines, Jenny Yaguache

Las autoras y los autores

El contenido de este libro ha sido sometido a un proceso de revisión de doble ciego por pares, semejante al sistema de revisión de un artículo científico para un journal. 


\section{1 \\ Prólogo}

\section{Transformaciones e interacciones: una reflexión crítica de la Comunicación Organizacional en el contexto digital}

A EVOLUCIÓN del ser humano, las organizaciones y la
sociedad en general, ha estado signada por la comunicación como
elemento estratégico que ha posibilitado la articulación y
relacionamiento del individuo con otros individuos, el desarrollo de
equipos estructurados; y la conformación de organizaciones de diversa
naturaleza para dinamizar la realidad social en atención a las dinámicas
culturales globales y locales preexistentes.

La comunicación entendida como un proceso que posibilita la interacción humana a partir de la significación y resignificación de la realidad, para insertarse en ésta, con la finalidad de poner en valor su participación en contextos sociales diversos, desde el intercambio y transferencia de mensajes para activar la dinámica de comunicación mediante la retroalimentación, la acción y la retroacción; motoriza las dinámicas organizacionales y territoriales en un marco que oscila entre la simplicidad y la complejidad.

Si bien la comunicación es entendida como una competencia individual la cual se constituye en un elemento estratégico para el relacionamiento y proyección de imagen del individuo; al tiempo que conforma una capacidad estratégica organizacional capaz dinamizar los procesos 
productivos con impacto en la calidad, la competitividad, la imagen, la reputación organizacional, la revaloración de las marcas productosservicios a estas asociadas.

En tal sentido, la comunicación se ha constituido en un elemento doblemente estratégico para las organizaciones, dado que si bien por una parte orienta la formulación de la gran estrategia organizacional conducente al establecimiento de una filosofía de gestión, objetivos y metas organizacionales; por otra parte, sirve de vehículo para conducir la estrategia organizacional posibilitando su conocimiento y aplicación efectiva en el orden estratégico operativo, facilitando la construcción de tácticas y acciones estratégicas para alcanzar los objetivos y las metas organizacionales.

Sin duda la comunicación estratégica organizacional afronta en la actualidad grandes retos en virtud de la mirada global en medio de la naturaleza dinámica y cambiante que gobierna los avances tecnológicos, impulsando la rápida y constante transformación, evolución y revolución de la tecnología que ha traído consigo nuevas formas de ver y abordar el mundo, nuevas sinergias relacionales, transformación digital, brechas tecnológicas, cambios culturales, evolución; y al mismo tiempo incertidumbre, vulnerabilidad e infoxicación.

Es así como cada día, la comunicación estratégica se constituye en un elemento para el impulso de valores como transparencia, confianza y credibilidad que posibiliten la construcción de puentes con los públicos organizacionales y los grupos de interés, opinión y poder; que confluyen en torno a las organizaciones a objeto de generar valor que posibilite el compromiso y fidelización de estos públicos; y, por ende, el posicionamiento y solidez de las marcas asociadas. 
Lo anterior aviva la necesidad de investigar en los comunicadores organizacionales más allá del rol o posición estratégica en la que se ubique en la organización, con la finalidad de socializar ante la comunidad en general las orientaciones teórico-prácticas para la optimización de la gestión estratégica de comunicación en individuos, grupos, organizacionales y territorios; en este sentido, se hace muy grato reconocer el esfuerzo articulado realizado desde la Universidad Técnica Particular de Loja, bajo la coordinación editorial de Mónica Abendaño Ramírez, Rosario Puertas Hidalgo y Karen Cesibel Valdiviezo Abad, en este Cuaderno Artesano de Comunicación titulado 'Comunicar: de la táctica a la estrategia', en el cual se concentran los esfuerzos de investigación de un dilecto grupo de comunicadores de Iberoamérica provenientes de Colombia, Ecuador y España, en reconocimiento de la importancia y revalorización de la comunicación estratégica.

El texto está estructurado en ocho capítulos en los cuales se abordan diversos aspectos en correspondencia con la comunicación estratégica organizacional, tales como: comunicación interna, comunicación digital, cambio, confianza, creatividad, credibilidad, diálogo organizacional, fidelización, planificación estratégica, posicionamiento, publicidad, públicos y grupos rol del comunicador; relaciones públicas, transformación digital, entre los más destacados; los cuales se presentarán de la siguiente manera:

En el primer capítulo, se presenta el trabajo desarrollado por Patricia Coll y Josep Lluís Micó, bajo el título 'Planificación Estratégica de la comunicación digital', en el cual se aborda el modelo de planificación estratégica de la comunicación digital que, en un entorno en cambio constante, se focaliza en el crecimiento a través de la combinación de creatividad y análisis, a partir del enfoque denominado growth hackingo, estrategia de posicionamiento, posibilitando ganar en coherencia, 
impacto y viralidad, mediante las sinergias entre acciones de publicidad y relaciones públicas.

En el segundo capítulo, se encuentra la investigación 'El plan estratégico de comunicación interna, herramienta para alinear al personal', elaborada por Lelia Zapata, el cual está centrado el diseño e implementación de un plan estratégico de comunicación interna (PECI), como contribución relevante del comunicador interno para gestionar los cambios y alinear la estrategia del negocio con la estrategia de comunicación.

En el capítulo tercero, es abordado desde la nominación 'De la comunicación interna al diálogo organizacional', un trabajo desarrollado desde la óptica de Mónica Abendaño y Laura Sánchez, el cual está centrado en la integración de los esfuerzos de la comunicación interna para la integración de los colaboradores internos mediante el diálogo organizacional que oriente la calidad de información, la efectividad del mensaje y la conexión de la gente.

Hacia el cuarto capítulo, se presenta la colaboración de Rosario Puertas Hidalgo y Cesibel Valdiviezo Abad, mediante el trabajo 'Transformación digital frente al rol del comunicador interno', en el cual la comunicación interna se presenta como elemento clave que orienta la transformación digital para la evolución y crecimiento de las organizaciones, a partir del compromiso, confianza y apoyo de los colaboradores de la organización. La comunicación interna se establece como punto focal para fortalecer la relación con los públicos, promover la imagen institucional, la reputación, la sostenibilidad. Revalorizando el comunicador interno, con un rol clave y estratégico en este proceso de transformación que debe contar no sólo con las habilidades requeridas para su desempeño, sino también con el conocimiento para contribuir al cambio cultural de la organización. 
En el quinto capítulo, se encuentra el estudio 'Uso estratégico de los medios digitales aplicados a la comunicación interna: Caso Cocoa', desarrollado por Gustavo Cusot e Isabel Palacios, el cual se orienta a partir de la mirada de la comunicación interna como factor para la consolidación de la cultura organizacional en el cual la estrategia adquiere un valor protagónico para la gestión a partir de un plan que se ajuste a las necesidades del momento integrando para ello los medios digitales.

Para el sexto capítulo, se encuentra la investigación desarrollada por Vanessa Duque Rengel y Ulianova Espinosa Jiménez, bajo el título: 'Medios de comunicación digital: herramientas de construcción de imagen y reputación', el cual tiene como propósito analizar los aportes de los medios digitales en la construcción de activos intangibles como imagen y reputación. En dicha investigación se vislumbra como los canales digitales y el soporte tecnológico impulsa la gestión efectiva del diálogo con los stakeholders, a partir de la cual se construyen nuevas formas de identidad online para individuos y organizaciones generando ventajas competitivas, relacionamientos y alianzas.

En el séptimo capítulo, desarrollado por Nancy Estella Vesga, bajo el título 'Inbound marketing: de la confianza a la venta. Comunicar con precisión y agregar valor en la información', donde se analiza el inbound marketing como estrategia de acercamiento al consumidor, para fidelizar a los clientes. Sin duda la comunicación cumple una función primordial de confianza permanente y cuidado con la información que se ofrece. El Inbound marketing ha captado el sentido de la información, ha potenciado la confianza con datos importantes y relevantes para los clientes logrando que la comunicación sea proactiva tanto para la empresa como para el consumidor.

Finalmente, se presenta, el octavo capítulo, con el estudio titulado: 'Infoxicación, un desafío para las empresas', desarrollado por Stefani 
Paladines Carranza y Jenny Yaguache Quichimbo, dentro del cual se consideran los desafíos organizacionales frente a problemáticas comunicacionales emergentes como: la sobreexposición informativa, la infoxicación, las fake news, los ciberataques, la polarización y alta participación de las audiencias que vulneran el contexto comunicacional y ameritan la generación de estrategias de credibilidad y confianza que apalanquen la reputación organizacional y generen cercanía y compromiso con los colaboradores, los públicos y grupos de interés en procura de una comunicación afianzada en la honestidad y la ética.

Es importante destacar de este texto la actualidad de sus contenidos y de la emergencia y necesidad de tratar los aspectos que se abordan, por lo que no resta sino invitar a los comunicadores de Iberoamérica y el mundo continuar la acción investigativa y la producción de teorías, prácticas y aprendizajes que se reflejen en literatura idónea para orientar la gestión estratégica de la comunicación en individuos y organizaciones en un contexto glocal; y disponerse a la lectura comprensiva de tan importante material.

Yanyn Rincón Quintero

PARA CITAR: Rincón Quinteros, Y. (2020). Transformaciones e interacciones: una reflexión critica de la Comunicación Organizacional en el contexto digital. En Puertas-Hidalgo, R., Abendaño, M. y Valdiviezo, C. (Eds.), (2020). Comunicar: de la táctica a la estrategia. Cuadernos Artesanos de Comunicación, nº178 (pp.7-12). La Laguna (Tenerife). 


\title{
Planificación estratégica de la comunicación digital
}

\author{
Patricia Coll Rubio \\ Universitat Ramon Llull \\ Josep Lluís Micó \\ Universitat Ramon Llull
}

\begin{abstract}
PARA CITAR: Coll Rubio, P. \& Lluís Micó, J. (2020). Planificación estratégica de la comunicación digital. En Puertas-Hidalgo, R., Abendaño, M. \& Valdiviezo-Abad, C. (Eds.), (2020). Comunicar: de la táctica a la estrategia. Cuaderno Artesanos de Comunicación, n¹78, pp.13-27. La Laguna (Tenerife).
\end{abstract}

\section{Resumen}

El capítulo aborda el modelo de planificación estratégica de la comunicación digital. En un entorno en constante cambio, la estrategia de comunicación digital se focaliza en el crecimiento a través del desarrollo de acciones que son fruto de la combinación de creatividad y análisis. Este enfoque, denominado growth hacking o estrategia de posicionamiento, impregna su planificación estratégica, que tiene una orientación alineada con la comunicación integrada de marketing. La comunicación integrada de marketing permite a las marcas ganar en coherencia, impacto y viralidad. De este modo, las marcas aprovechan al máximo las sinergias entre acciones de publicidad y relaciones públicas. Su desarrollo se lleva a cabo en las cuatro fases del modelo de planificación estratégica de la comunicación: investigación, planificación, ejecución y evaluación. 
Palabras claves: growth hacking; relaciones públicas, publicidad, planificación estratégica, comunicación integrada de marketing.

\section{La comunicación digital desde una perspectiva integrada}

$\mathrm{E}$ STE CAPÍTULO aborda la planificación estratégica de la comunicación digital como un conjunto de técnicas de marketing y comunicación interrelacionadas, en línea con el concepto de comunicación integrada de marketing (Schultz y Kitchen, 2000:17).

Especialmente, en el ámbito digital, donde los públicos tienen un papel activo en su relación con las marcas, éstas: "no se construyen como si se tratara de un rompecabezas. Comparar una marca con un puzzle sugiere que solo existe una combinación correcta de sus múltiples piezas, que la arquitectura global de la campaña está perfectamente diseñada de antemano y que los jugadores solo tienen que reconstruirla. Pero es justo lo contrario. Lo único que una marca puede hacer y hace es enviar diferentes piezas (ya sea a través de una nota de prensa o de un anuncio en televisión). El público tiene que decidir si crea su propia combinación específica, quedándose y recordando lo que le ha gustado, e ignorando lo que no ha sido de su agrado. Una comparación con las piezas de Lego, realizada por Mediaedge: CIA, resulta mucho más acertada porque describe un proceso recíproco y dinámico. Las piezas de Lego se pueden combinar de infinitas maneras, y es la persona que construye la que decide qué aspecto tendrá la construcción una vez concluida". (Himpe, 2007:208)

Mediante las acciones de marketing y comunicación, las marcas lanzan esas piezas de Lego con el objetivo de captar la atención de sus públicos, para que, luego ellos mismas las encajen cuándo y cómo deseen. Por ello, como veremos a lo largo de este capítulo, la comunicación digital forma parte de una estrategia integrada que 
aprovecha al máximo las sinergias, combinando creatividad y análisis para lograr el crecimiento.

La comunicación integrada de marketing, como planificación armoniosa de la comunicación en cualquiera de sus formatos, logra que a esos públicos les pueda llegar "un mensaje claro, coherente y convincente sobre la empresa y sus productos" (Kotler, 2003:131).

Este enfoque integrado de la comunicación es imprescindible en un contexto híbrido, en el que imperan la multiplicación de canales, la segmentación de audiencias y la personalización en la relación con los públicos, tanto en el terreno online como en el offline. Para llevarlo a cabo, en este entorno, que cambia además a gran velocidad, la planificación estratégica de la comunicación digital debe abordarse desde el aprendizaje constante y la experimentación (Coll y Micó, 2018:161).

La estrategia de la comunicación digital y su enfoque de posicionamiento está centrada en el crecimiento. Para ello, desarrolla acciones de comunicación digital en las que se combinan creatividad y análisis, con una toma de decisiones basada en datos y una planificación flexible, bajo el prisma del aprendizaje constante que le permite adaptarse al entorno cambiante.

\section{E1 'growth hacking' como enfoque de la comunicación digital}

La comunicación digital alinea su estrategia a los objetivos de crecimiento del growth hacking (Ellis \& Brown, 2018) o estrategia de posicionamiento, que desarrolla sus acciones combinando creatividad y análisis.

El growth hacking, como pluridisciplina, nace de la necesidad de las empresas digitales emergentes, de encontrar un perfil profesional que 
combinara los conocimientos tecnológicos con la creatividad. El creador del término, Sean Ellis, define un growth hacker como "una persona cuyo verdadero norte es el crecimiento que debe tener la creatividad para descubrir maneras únicas de impulsar el crecimiento, además de probar o evolucionar las técnicas probadas por otras compañías" (Ellis, 2010).

El término growth hacking se popularizó más allá del ecosistema startup a partir de los planteamientos de Chen (2012), para quién un growth hacker es aquel profesional creativo y analítico que se pregunta constantemente cómo puede conseguir clientes para su negocio y la responde de modo analítico e innovador, mediante pruebas A/B, landing pages, técnicas virales y estrategias de marketing de contenidos que trabajan el SEO, entre otras muchas posibilidades. De hecho, para Chen, el growth hacking no es un rol dentro de la organización, sino una filosofía que debe impregnarla en su conjunto. Por ello, tal como destaca el propio Ellis, junto con Brown (Ellis y Brown, 2018), el growth backing trasciende las fronteras de la comunicación y el marketing. De hecho, está detrás de decisiones de negocio clave como los acuerdos de Media For Equity, fórmula que consiste en un intercambio de acciones entre un startup y un grupo de comunicación a cambio de espacio publicitario.

De este modo, en el terreno comunicativo, el growth hacking impregna toda la filosofía estratégica y táctica de las marcas. Así, por ejemplo, con el objetivo final de crecimiento, la visión growth hacker subyace tras el desarrollo de tácticas como el newsjacking (Scott, 2011), consistente en abordar acciones comunicativas innovadoras tras monitorizar los temas de actualidad que interesan al público objetivo. El newsjacking, para llevarse a cabo, recurre a la monitorización de medios de comunicación y al big data que generan las redes sociales para conocer los temas que interesan al público objetivo de la marca. A partir de ahí, se crean contenidos que pueden convertirse en virales. Incluso pueden 
llegar a captar la atención de los medios de comunicación que, cada vez más, consideran las redes sociales como una fuente de información en su proceso de media catching. En este sentido, el growth hacking y prácticas que derivan de él, como el newsjacking, presentan una estrategia integrada, en línea con la concepción de comunicación integrada de marketing.

\subsection{Antecedentes: el marketing de guerrilla}

El germen de este tipo de acciones, según autores como Herttua, Jakob, Nave, Gupta y Zylka (2016), estaba ya presente en el planteamiento del marketing de guerrilla que tanto pequeñas empresas como otras de mayor magnitud contemplan, desde hace décadas, como métodos no convencionales, para lograr notoriedad en sus estrategias de marketing y comunicación.

El éxito de acciones de street marketing, innovadoras campañas virales, sorprendentes experiencias transmedia o impactantes flashmobs, por ejemplo, constatan la eficacia de la creatividad como vía para lograr la interacción con las personas, en muchos casos, con una inversión mucho menor que a través de la utilización de métodos convencionales de marketing, como la publicidad. De hecho, la comunicación digital se centra en cultivar el ingenio para crear expectación, sorprender y conseguir un efecto viral en las redes sociales, combinándose incluso con acciones de marketing llamativas en lugares públicos, ya que los usuarios intrigados o impactados suelen compartir fotografías o contenidos.

El marketing de guerrilla se popularizó a partir de los años ochenta del pasado siglo, con Levinson, quien considera que "la teoría del marketing de guerrilla dice que sus principales inversiones deberían ser tiempo, energía e imaginación" (Levinson, 2009:9). En la misma línea, Salas, Andrade y Tavarez (2018:153) definen el marketing de guerrilla 
como, "una filosofía del marketing, que sustituye los medios masivos por algo original y distinto".

La experimentación, propia del enfoque del growth hacking, y su planteamiento integrado, están presente en el marketing de guerrilla que se centra en "la esencia de la creatividad: combinar dos o más elementos que no hayan sido combinados" (Levinson, 2009:62).

La práctica del marketing de guerrilla, según señalan Torreblanca y Lorente (2016), engloba acciones de diversa índole entre las que destacan, en el ámbito offline, el ambient marketing y el street marketing. La diferencia entre ambos tipos de acciones es que, mientras que en el ambient marketing las acciones son estáticas y se apoyan en la transformación de elementos urbanos existentes, en el street marketing, se interactúa con las personas. En la misma línea, Bravo (2013:15-17) divide el marketing de guerrilla en cuatro campos, que con el nacimiento de Internet se extienden al mundo online: calles y sitios públicos, eventos, productos cotidianos e Internet.

En la era digital, el marketing de guerrilla ha evolucionado mucho ya que "Internet y la web 2.0 son canales que ofrecen todas las posibilidades para cumplir con la definición inicial de Levinson sobre el marketing de guerrilla: obtener el máximo beneficio con el mínimo de recursos invertidos. De hecho, el marketing de guerrilla tradicional o 1.0, realmente ya no cumple con el requisito de los costes mínimos. Sobre todo, las grandes marcas de gran consumo, invierten mucho dinero en cada una de sus acciones para llamar la atención del comprador. Una pyme o startup no puede competir en este mismo campo. Aun así, tiene otras herramientas efectivas a su disposición. El canal online y el offline no solo no son separables, sino que incluso resultan totalmente permeables" (Bravo, 2013:21). 
El éxito de acciones de este tipo depende de la investigación y la planificación estratégica: "solo si los anunciantes conocen los hábitos y las expectativas de su grupo objetivo, pueden provocar efectos sorpresa y efectos de difusión. Generar nuevas ideas requiere un gran esfuerzo de investigación y planificación" (Hutter y Hoffmann, 2011:10).

\section{La planificación estratégica de la comunicación digital}

La planificación estratégica es una orientación de intervención o enfoque de acción destinado a cumplir con unos objetivos (Xifra, 2007:10). Estos objetivos, en el caso del growth hacking, se centran principalmente en el crecimiento (Ellis y Brown, 2018) y, en gran parte, en toda estrategia de la comunicación digital.

Entre los diferentes modelos de planificación estratégica, el modelo en espiral construido por Marston (1963) bajo el acrónimo RACE (Research, Action, Communication y Evaluation) es "uno de los más citados en el ámbito académico, ya que constituye un punto de referencia capital" (Matilla, 2008:74).

\subsection{Investigación}

La primera fase del modelo RACE es la investigación, que, de acuerdo con Cutlip y Center (2001), esta es la fase más difícil, ya que a menudo no se sabe cómo plantearla y, además, cuenta con la oposición de quienes no la consideran necesaria.

Las posibilidades y complejidad de la investigación han ido en aumento con la irrupción de las tecnologías de la información, que permiten obtener datos masivos, denominados como big data (Braulio y Curto, 2015). Además, tal como enfatiza Kaushik (2009:209), existen experimentos controlados para realizar pruebas (como los test A/B o 
los test multivariantes) que lo permiten. Esta labor de investigación "es un arte porque, como un pintor, el analista recurre a una paleta de colores diversa (fuentes de datos) para encontrar la combinación perfecta” (Waisberg y Kaushik, 2009:5).

Además de estar en el inicio de cualquier estrategia, ya que la investigación permite "conocer y comprender qué está sucediendo" (Cuenca, 2012:47), se debe recurrir a ella durante todo el desarrollo del plan de comunicación porque "es una herramienta multiusos que se utiliza en todas las fases de un proceso de un programa de comunicación" (Cuenca, 2012:125).

\subsection{Planificación}

La segunda fase del modelo RACE (Marston, 1963) es la planificación, considerada como el proceso de establecimiento de las metas y objetivos y determinación de la manera de lograrlos (Wilcox et al, 2012). En la comunicación digital, la planificación se realiza en el corto plazo y se plantea como flexible y adaptable al entorno cambiante, para aprovechar en todo momento las oportunidades de comunicación y tener capacidad de reacción ante los imprevistos. Las acciones de comunicación digital se calendarizan por trimestres, con múltiples acciones tácticas que se deciden en el día a día y que siempre responden a objetivos concretos y medibles.

\subsection{Ejecución}

La tercera fase de ejecución de las acciones de comunicación, se inscribe en la línea establecida por las dos fases precedentes, la investigación y la planificación. Las acciones previamente planificadas se llevan a cabo en la fase de ejecución, durante la cual se recurre tanto a la publicidad como a las relaciones públicas, incluyendo técnicas que están en la frontera entre una y otra disciplina, como el influencer 
marketing, el marketing de contenidos o el branded content (Coll y Micó, 2019:127).

La mayor interacción con los públicos en la sociedad red, hace que la reputación de las marcas se vea mucho más expuesta y que la gestión de crisis de comunicación sea prácticamente una labor constante. Por ello, otros ámbitos de actuación clave de la comunicación digital durante la ejecución de las acciones es la gestión de reputación y la comunicación de crisis que Pearson y Mitroff (1993:47), dividen en cinco fases: detección de señales, preparación y prevención, contención de daños, recuperación y aprendizaje.

\subsection{Evaluación}

Prácticamente en paralelo a la ejecución, se realiza un seguimiento a tiempo real de las acciones, midiendo de forma lo más científicamente posible la consecución de los objetivos, para poder rectificar o incluso replantear la estrategia (Coll y Micó, 2019:129).

La monitorización continua de los resultados, de las acciones de comunicación digital, forma parte esencial de la cuarta y última fase de la espiral del modelo RACE: la evaluación. En esta fase, se evalúa el éxito de cada acción a partir de indicadores clave, que permiten una toma de decisiones basada en datos. De esta forma, la investigación está al principio y al final de esta espiral, que Matilla describe como "una línea ascendente que, partiendo en su nacimiento de la investigación, avanza hacia la acción, se desplaza por la comunicación y, finalmente, desemboca y termina en la evaluación".

En este modelo cerrado de Marston (1963), "cada etapa conduce indefectiblemente a la siguiente, de modo que la última etapa (Evaluation), una vez superada, obligará a recurrir nuevamente a la primera (Research)" (Matilla, 2008:74). De acuerdo con Wilcox, 
Cameron y Xifra (2012:12)., el modelo RACE es, en definitiva, "un proceso que puede considerarse como un ciclo sin fin".

En el ámbito de las empresas emergentes digitales, este ciclo sin fin se desarrolla en paralelo a la metodología Lean Startup, que se centra en lanzar "el mínimo producto viable", que permite medir de forma continua el impacto, siguiendo el "circuito crear-medir-aprender con un mínimo esfuerzo y en el mínimo tiempo de desarrollo" (Ries, 2012:16).

La estrategia de comunicación digital, por tanto, debe contar con una planificación flexible, que parta siempre de la investigación y evalúe los resultados de sus acciones, que se plantean combinando creatividad y análisis, bajo el foco del aprendizaje constante, la experimentación y la adaptación a la velocidad de cambio en el entorno.

\section{Campos de actuación de la comunicación digital}

El enfoque del growh hacking centra la estrategia de la comunicación digital, que se apoya en la creatividad, el análisis y el aprendizaje constante a través de la experimentación para lograr su objetivo esencial de crecimiento.

En cuanto a sus campos de actuación que, como se ha señalado, se plantean desde la óptica de la comunicación integrada de marketing, la comunicación digital recurre a técnicas publicitarias y de relaciones públicas, con técnicas que están en la frontera entre una y otra disciplina, como el influencer marketing o el marketing de contenidos.

\subsection{Medios ganados: relaciones públicas}

Tal como señala Aced (2013:62), "la empresa siempre había podido estar presente en los medios de tres formas: a través de los medios 
propios (revistas corporativas, intranet, web corporativa), de los medios comprados (publicidad) y de los medios ganados (publicity). Actualmente, esta última vía, a través de las relaciones públicas, cobra un interés especial".

Las relaciones públicas constituyen la disciplina encargada de gestionar las relaciones entre una organización y sus públicos (Bernays, 1923).

La práctica moderna, las relaciones públicas “son algo más que una simple persuasión y fomentan una comunicación abierta bidireccional mutua" (Wilcox et al, 2012:6).

\subsection{Medios pagados: publicidad}

Las campañas publicitarias tienen un peso destacado entre las acciones de comunicación y se desarrollan tanto en medios digitales y redes sociales, de forma coordinada con las campañas offline, como las de televisión, que sigue siendo un soporte publicitario de primer orden.

Desde el inicio, la publicidad se plantea pensando en obtener la máxima difusión en todos los canales posibles. De este modo, en línea con su enfoque growth hacker, se aprovechan al máximo las sinergias entre las acciones, adaptando los contenidos y la planificación a cada público y canal.

\subsection{Medios propios: contenidos y viralidad}

Con ese objetivo de crecimiento del growth hacking, la comunicación digital crea y cura contenidos para lograr que su mensaje llegue al público objetivo, y, además llame a la acción y que se propague.

El fenómeno de la viralidad responde a un proceso que se desencadena si un mensaje a un usuario susceptible de propagarlo, tal como describe 
Rushkoff (1994:15): "así como los científicos usan virus para combatir ciertas enfermedades dentro del cuerpo humano o para etiquetar células peligrosas para su destrucción por los propios anticuerpos de la persona, los activistas de los medios usan virus para combatir lo que ven como enemigos de nuestra cultura. Los virus de los medios de comunicación, ya sean intencionales, cooptados o espontáneos, conducen a la mutación de la sociedad ya algún tipo de evolución”.

El concepto de marketing viral partió del emblemático de Hotmail: "la inspiración vino del patrón de Hotmail, el servicio de correo electrónico que se puso en marcha en 1996. Tim Draper convenció a Hotmail de incluir un mensaje en tono promocional con un link URL en cada mensaje enviado por un usuario de Hotmail. Allí estaba uno de los elementos clave del marketing viral: cada cliente se convierte en vendedor" (Jurvetson, 2000:110).

En línea con el enfoque de Rushkoff, Rosen (2001:196) señala que "dado que cada cliente recibe información de un amigo a través de la Red puede reproducirla de forma simultánea y enviarla a docenas, cientos o miles de otras personas, esta forma de marketing a través de Internet se denomina 'marketing viral'. Así como el resfriado común se contagia a través de los estornudos, la tos y el contacto con las manos, ahora es posible ofrecer la divulgación a través de tarjetas electrónicas, cupones electrónicos y mensajes por correo electrónico que instan a invitar a un amigo".

En cuanto a los factores facilitadores de la viralidad, Berger y Milkman (2012:192) destacan que "el contenido positivo es más viral que el contenido negativo, pero la relación entre emoción y transmisión social es más compleja que la valencia sola. La viralidad es parcialmente impulsada por la excitación fisiológica. El contenido que evoca emociones elevadas positivas (temor) o negativo (enojo o ansiedad) es más viral". 
Kaplan y Haenlein (2010) resaltan que, sobre todo, en una campaña de marketing viral hay que dar el mensaje correcto a los mensajeros correctos en el entorno adecuado. En este sentido, los denominados influencers pueden tener un efecto amplificador que facilite la viralidad.

\section{Referencias bibliográficas}

Aced, C. (2013). Relaciones Públicas 2.0. Cómo gestionar la comunicación corporativa en el entorno digital. Barcelona: Editorial UOC

Berger, J., y Milkman, K. L. (2012). «What makes online content viral?». Journal of Marketing Research, 49(2), pp.192-205.

Bernays, E.L. (1998). Cristalizando la Opinión Pública. Barcelona: Editorial Gestión 2000

Braulio, N. y Curto, J. (2015). Customer analytics: mejorando la inteligencia del cliente mediante los datos. Barcelona: Editorial UOC.

Bravo, C. (2013). Marketing de guerrilla para emprendedores valientes: Atrévete con nuevas «armas» a vender más y mejor. La esfera de los libros.

Chen, A. (2012). Growth hacker is the new VP Marketing. Andrew Chen. Recuperado de http://andrewchen.co/how-to-be-a-growthhacker-an-airbnbcraigslist-case-study/

Coll, P. y Micó, J.L. (2018). Marketing y comunicación en la nueva economía. Barcelona: Editorial UOC.

Coll, P. y Micó, J.L. (2019). Estrategias de publicidad y relaciones públicas en la era digital. Barcelona: UOC Press.

Cuenca, J. (2012). Las auditorías de relaciones públicas: Origen y evolución histórica, tipos de auditorias, modelos y variables de medición. Barcelona: Editorial UOC.

Cutlip, S. M. y Center, A. H. (2001). Relaciones Públicas eficaces. Barcelona: Gestión 2000.

Ellis, S. (2010). Find a growth hacker for your startup. Startup Marketing [web]. Recuperado de http://www.startupmarketing.com/where-are-all-the-growth-hackers /

Ellis, S. y Brown, M. (2018). El método Hacking Growth: Qué hacen compañias explosivas como Facebook, Airbnb y Walmart para ser lideres en el mercado. Barcelona: Penguin Random House. 
Herttua, T., Jakob, E., Nave, S., Gupta, R. y Zylka, M. P. (2016). Growth Hacking: Exploring the Meaning of an Internet-Born Digital Marketing Buzzword. In Designing Networks for Innovation and Improvisation. pp. 151-161

Himpe, T. (2007). La publicidad ha muerto: larga vida a la publicidad. Barcelona: Blume.

Hutter, K. y Hoffmann, S. (2011). Guerrilla marketing: The nature of the concept and propositions for further research. Asian Journal of Marketing, 5(2) pp. 1-16

Jurvetson, S. (2000). What exactly is viral marketing. Red Herring, 78, 110112.

Kaplan, A. M., y Haenlein, M. (2010). Users of the world, unite! The challenges and opportunities of Social Media. Business horizons, 53(1), pp.59-68.

Kaushik, A. (2009). Web Analytics 2.0: The Art of Online Accountability and Science of Customer Centricity. John Wiley \& Sons.

Kotler, P. (2003) Marketing Management. New Jersey: Prentice Hall. Levinson, J. C. (2009). Marketing de guerrilla. Morgan James Publishing. Marston, J. E. (1963). The Nature of Public Relations. New York: McGraw-Hill.

Matilla, K. (2008). Los modelos de planificación estratégica en la teoría de las relaciones públicas. Barcelona: Editorial UOC.

Pearson, C. M., y Mitroff, I. I. (1993). From Crisis Prone to Crisis Prepared: A framework for Crisis Management. Academy of Management Perspectives, 7(1), 48-59.

Ries, E. (2012). El método Lean Startup: Cómo crear empresas de éxito utilizando la innovación continua. Barcelona: Grupo Planeta.

Rosen, E. (2002). The anatomy of buz₹: New York: Crown Publishing Group.

Rushkoff, D. (1994). Media Virus. New York: Random House Publishing Group.

Salas, L Andrade y F. Tavarez, E. M. (2018). Tácticas de marketing de guerrilla en pequeñas y medianas empresas. Universidady Sociedad, 10(3), 152-158.

Schultz, D. E., y Kitchen, P. J. (2000). A response to 'Theoretical concept or management fashion. Journal of Advertising Research, 40(5), 17-21. 
Scott, D. M. (2011). Newsjacking: How to Inject Your Ideas Into a Breaking News Story and Generate Tons of Media Coverage. John Wiley \& Sons.

Torreblanca, F. y Lorente, P. (2012). Marketing de guerrilla. Lo no convencional triunfa. 3C Empresa, 1(9). 1-14.

Wilcox, D. L., Cameron, G. T. y Xifra, J. (2012). Relaciones Públicas: Estrategias y Tácticas. Madrid: Pearson Educación

Waisberg, D., y Kaushik, A. (2009). Web Analytics 2.0: empowering customer centricity. The Original Search Engine Marketing Journal, 2(1), 5-11.

Xifra, J. (2007). Tècniques de les relacions públiques. Barcelona: Editorial UOC. 



\title{
El plan estratégico de comunicación interna, herramienta para alinear al personal
}

\author{
Lelia Zapata \\ Universidad Anáhuac
}

\begin{abstract}
PARA CITAR: Zapata, L. (2020). El plan estratégico de comunicación interna, herramienta para alinear al personal. En Puertas-Hidalgo, R., Abendaño, M. \& Valdiviezo-Abad, C. (Eds.), (2020). Comunicar: de la táctica a la estrategia. Cuadernos Artesanos de Comunicación, n¹78 (pp.29-45). La Laguna (Tenerife).
\end{abstract}

\section{Resumen}

La comunicación interna reconocida como función estratégica para liderar la cultura de cambio, tiene como tarea clave el diseño de un plan estratégico de comunicación interna (PECI). Este trabajo pone en relevancia la gestión del cambio y el reto de implementar una comunicación interna estratégica. Para ello, expone las tendencias digitales aplicadas a la comunicación interna, cuya principal novedad es el uso de chatsbots. Explica que la comunicación estratégica es clave para toda organización y sugiere a las empresas organizar y articular los mensajes dirigidos a sus audiencias internas desde un plan estratégico de comunicación interna. Este plan cuyo responsable suele ser el Dircom, permite alinear a la plantilla con los objetivos y la estrategia global de la empresa. Concluye que los colaboradores internos son aliados decisivos para que la empresa avance en sostenibilidad, ya que el proyecto de futuro y la innovación depende de las personas. 
Palabras clave: plan estratégico de comunicación interna, comunicación estratégica, comunicación interna estratégica, estrategia digital interna, objetivos estratégicos

\section{Introducción}

T A COMUNICACIÓN interna sigue evolucionando hacia el 1 trabajo colaborativo, es digital y su responsable asume un rol de animador del diálogo en coherencia con el entorno actual, cada vez más digitalizado y en continuo cambio.

Aunque no todas las entidades implementan estrategias de comunicación interna, son cada vez más las empresas vanguardistas comprometidas con el cambio y con la comunicación con sus colaboradores internos. Según el estudio de Accenture Tecnology Vision (2016), las organizaciones que adaptan sus negocios a la transformación digital, trabajan desde una comunicación estratégica.

Atendiendo a las prácticas empresariales, son cada vez más las empresas que implantan una estrategia de comunicación dirigida a sus públicos internos, de esta manera "aspiran a conseguir una plantilla sensibilizada y alineada con los objetivos estratégicos" (Cees Van 2012:82). Para generar ese alineamiento sus responsables de comunicación en coordinación con las áreas claves de la organización, diseñan un plan estratégico con el fin de alinear personas con la estrategia empresarial.

Transparencia, motivación y credibilidad son algunas de las ventajas de aplicar este plan estratégico. La comunicación estratégica aspira a mantener o incrementar el compromiso de los colaboradores internos y fortalecer su orgullo de pertenencia. 


\section{Personas, innovación y comunicación estratégica}

Para Berger Roland (2016), uno de los referentes en digitalización, la transformación digital ya es una necesidad ineludible para muchas organizaciones que optan por planes de cultura digital. De acuerdo con las indagaciones de Berger, las empresas españolas empiezan a dominar los usos digitales básicos, aunque todavía existe un cierto recelo a los usos más avanzados, que solamente son aprovechados por unas pocas empresas innovadoras.

Las empresas innovadoras apuestan por la comunicación ya que sin esta función todo intento de innovar quedaría sin protagonismo. Son conscientes que promover la innovación es un proceso lento que requiere apertura al cambio, cuestionamientos, creatividad. Innovar es un proceso creativo, que demanda un conjunto de actividades desarrolladas en un periodo de tiempo, con el fin de mostrar por primera vez una idea en forma de productos nuevos o mejorados, o bien presentar nuevos procesos, servicios o técnicas de gestión. Aclara Gonzales Hermoso (2001:37) "las actividades de I+D suelen ser las responsables de los procesos de innovación, aunque es posible encontrar empresas innovadoras que no llevan a cabo acciones de I+D”.

Y esto es así, porque innovar demanda trabajo compartido, aportes, voluntad de emprender, gusto por el riesgo, por lo nuevo. Ciertamente, se innova cuando se gestiona el talento y se generan entornos favorables para el flujo de ideas, cuando se promueve el conocimiento compartido de la mano del diálogo. Por tanto, innovar equivale a dar voz a la inteligencia de la organización ya que son las personas las protagonistas de la innovación.

Son las personas, concluye el estudio Vision Technology (2016), quienes facilitan y hacen posible el cambio, por tanto, deben ser las 
protagonistas; estas personas son las que aportan gracias a la conexión que permiten las nuevas tecnologías, las plataformas colaborativas y las redes sociales.

Es así como, la comunicación digital se consagra como la palanca que sirve para conectar personas, permitiendo mantener un flujo constante de información, de conocimiento compartido, de aportes y retroalimentación. Estas interacciones no deben limitarse a un área o a una unidad del negocio, ya que, el objetivo debe ser convertir la comunicación digital en el eje vertebral de la organización. De ahí la necesidad de incluirla en los planes de comunicación interna estratégica.

Para que la comunicación digital consiga los objetivos esperados, se requiere del diseño de una estrategia, es decir debe contar con una política de comunicación y seguir unas acciones intencionales. De modo que la comunicación digital debe ser estratégica.

\section{La comunicación estratégica: mensajes alineados a la estrategia organizacional.}

Argenti (2016), uno de los referentes internacionales en la materia, define la comunicación estratégica como la comunicación alineada e integrada con la estrategia global de la compañía, que impulsa y mejora el posicionamiento estratégico de la organización. Explica que una estrategia de comunicación efectiva es aquella que permite emitir mensajes claros y comprensibles que generen confianza. Estos mensajes deben ser contados con pasión de forma coherente y reiterada a sus audiencias internas.

Con esta definición Argenti se pone en valor la urgencia al gestionar la comunicación de forma estratégica con el apoyo directivo, de modo que sirvan para articular la dirección estratégica de la empresa y para 
motivar a la gente para que la apoye. En esta misma línea coincide Nuria Saló (2007:23), quien considera que, los directores como líderes del más alto nivel están llamados a convertirse en actores de la comunicación, precisamente "una de sus responsabilidades debe ser apoyar y motivar a sus equipos". El papel y la implicación de los equipos directivos son decisivos ya que gracias a sus cargos acceden a información significativa que deben transmitir y garantizar el buen funcionamiento de los flujos comunicativos.

Gráfico 1. Ciclo de la comunicación estratégica aplicada a las audiencias internas

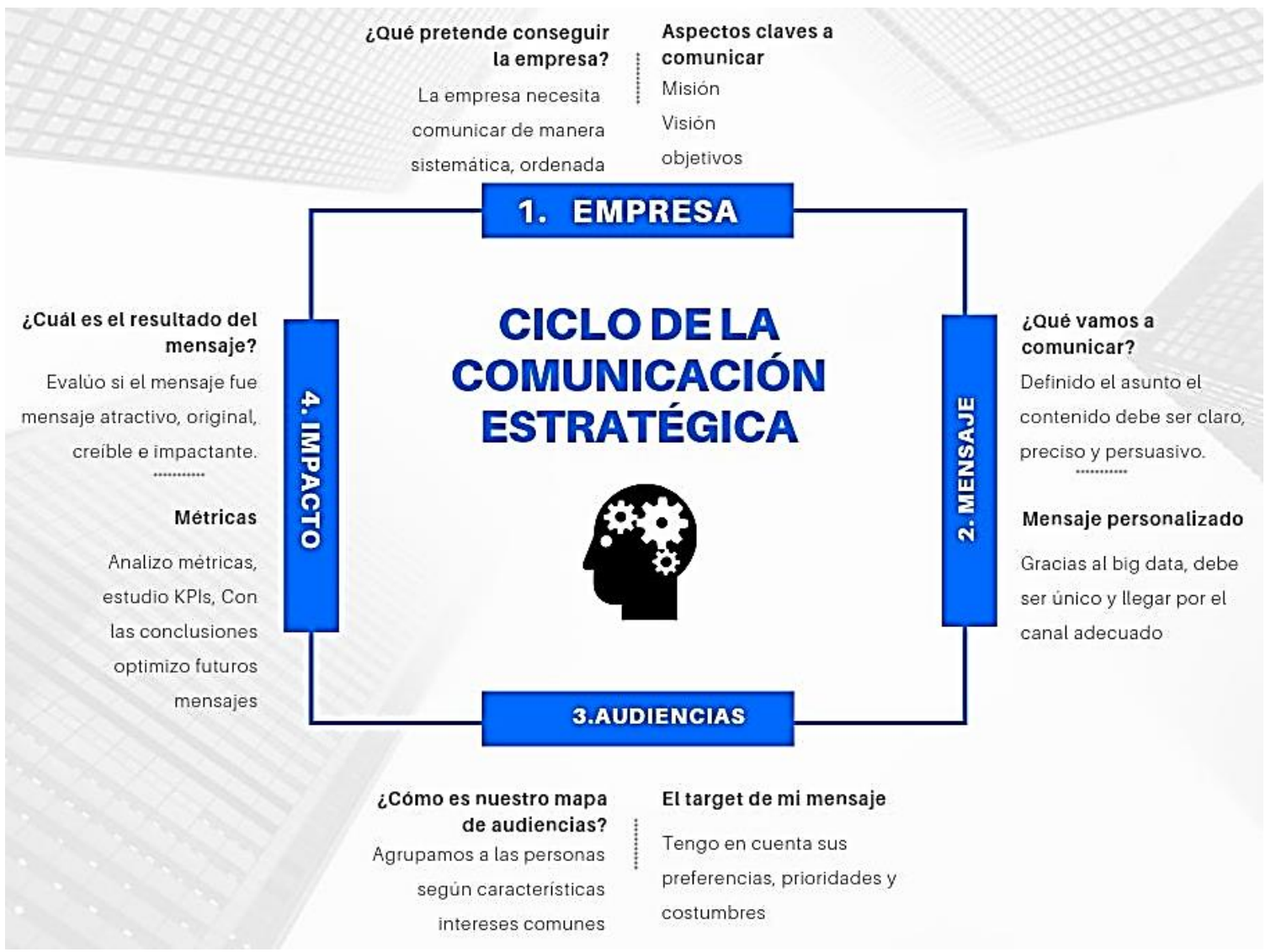

Fuente: Elaboración propia

Estas interacciones se convierten en urgentes a medida que las empresas aumentan su tamaño, visibilidad y mercado. En estos casos, las entidades se ven ante la necesidad de utilizar una estrategia de comunicación coherente para gestionar sus recursos intangibles como son la marca y reputación interna y así, conseguir una empresa 
sostenible. Precisamente, para Argenti (2016), una de las claves para la construcción de proyectos empresariales sostenibles a largo plazo es la coherencia. La coherencia favorece la asimilación de los mensajes, los cuales deben ir acordes con la estrategia empresarial y ser diseñados con claridad. El gráfico 1 resume el ciclo de la comunicación estratégica aplicada a las audiencias internas.

Los mensajes dirigidos al personal de la organización deben ser sistemáticamente estudiados, según los objetivos empresariales, el asunto a comunicar, el mapa de audiencias, así como medidos en su impacto. Un café para todos es una expresión obsoleta, la comunicación gracias a los big data puede ser personalizada. Cuando esta comunicación se desarrolla desde una estrategia, el empleado se encontrará, más integrado en el proyecto corporativo y apreciará que es tomado en cuenta en las decisiones.

\section{La comunicación interna estratégica, prioridad que facilita la transformación}

La comunicación interna estratégica no es una opción, es una prioridad que impulsa la transformación digital, facilita la gestión del cambio cultural que impone la economía digital y favorece la consecución de los objetivos finales de cualquier organización. La comunicación interna estratégica aporta credibilidad y genera confianza en las audiencias internas respecto a los proyectos puestos en marcha por las empresas y es la herramienta a través del cual se explican cambios, logros y dificultades.

Así lo testifica Dircom (2017) cuando menciona el estudio realizado por el European Communication Monitor (2016:36-41), el mismo que subraya el valor de la comunicación estratégica en un contexto de cambio, gestión que también es reconocida en su importancia, por parte de empresas latinoamericanas, de acuerdo con las conclusiones 
del Latin American Communication Monitor. Los referidos estudios, el primero en empresas europeas y el segundo, en empresas latinoamericanas, hacen un seguimiento a la profesión y a la gestión de la comunicación estratégica. Ambos incluyen en sus investigaciones preguntas sobre los desafíos contemporáneos y las tendencias que impactan en el ámbito de la comunicación y coinciden en "la importancia de contar con un departamento de comunicación que consiga impulsar una estrategia de comunicación que contribuya decididamente a los objetivos del negocio" [Dircom] (2017:38).

En el caso español, estas conclusiones han quedado confirmadas con el Estudio el Estado de la Comunicación 2018, realizado un año más tarde por la Asociación de Directivos de Comunicación, el cual prevé que “en los próximos años destacarán: la comunicación interna y la gestión del cambio" [Dircom] (2018:7) y concluye que la comunicación interna es una tendencia clara que permite difundir el proyecto colectivo.

Podemos, por tanto, concluir que la comunicación interna estratégica será imprescindible para gestionar el cambio y avanzar en digitalización.

\section{Tendencias en la comunicación interna: personalización, bots, small data}

Los cambios tecnológicos también afectan a las comunicaciones internas digitalizadas, las cuales presentan como principales tendencias: contenidos personalizados, big data, small data y bots.

Las acciones estratégicas consideradas como más relevantes por las organizaciones españolas son "usar el big data y los algoritmos para la comunicación, conectar las estrategias de la organización con la comunicación e impulsar la comunicación interna" [Dircom] (2018:137). 
El gráfico 2 muestra las acciones de comunicación estratégica que serán tendencia en los últimos años, según Dircom España.

La principal tendencia en comunicación digital es el uso del big data, el cual resulta clave para el comunicador, quien gracias a los datos puede tomar mejores decisiones. El big data permite predecir, medir el comportamiento de las audiencias internas y así, afinar la estrategia de comunicación. Sin embargo, según la Asociación de Directivos de Comunicación esta principal tendencia se verá superada por el small data, con este recurso. "Los detalles serán más cualitativos y minuciosos y como consecuencia, ganarán una mejor efectividad a la hora de ofrecer al usuario experiencias únicas y personalizadas" [Dircom] (2018:24).

Gráfico 2. Acciones estratégicas que serán tendencia en comunicación estratégica

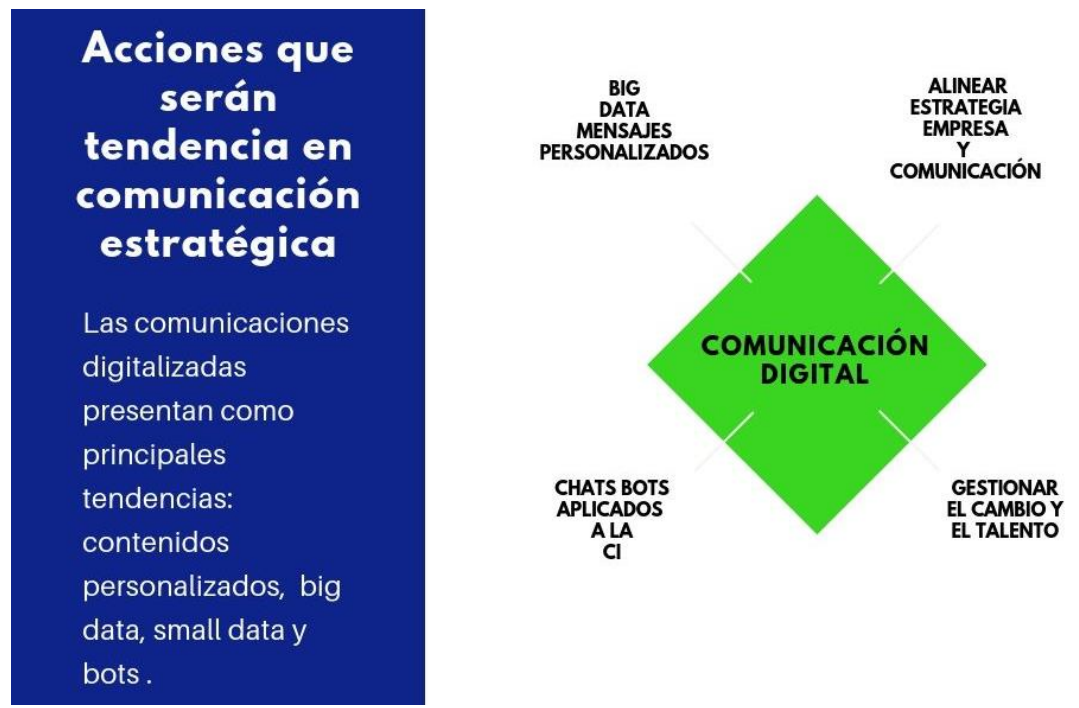

Fuente: Elaboración propia

La inteligencia artificial es otra tendencia que está irrumpiendo con fuerza en la comunicación y son cada vez más las empresas que las utilizan en sus conversaciones. Esta tecnología está irrumpiendo en el panorama de la comunicación y seguirá afectando, según Silvia Leal 
(2018:32), "a la forma de comunicarnos. Hay quien dice que en el 2021 hablaremos más con chatbots".

Los bots y algoritmos pueden generar contenidos e interactuar con los diferentes públicos, igual que lo haría una persona, con una capacidad de conversación simultánea. Los bots o chatbots aplicados a la comunicación interna tienen grandes aplicaciones. Estos asistentes virtuales que se pueden configurar e implementar en proyectos de comunicación interna, por ejemplo, para dar la bienvenida, para preguntar, para brindar la información precisa de alguna actividad de la empresa o para ayudar en la búsqueda de información.

En consonancia con estos cambios, en palabras de Tarrés (2018:8), la opción del comunicador debe ser sumarse a estas tendencias. Dice, "estos son los cambios a los que debe estar abierto un comunicador. La clave no podrá ser evitar la ola sino surfearla" / ... ( Tarrés, 2018:8).

\section{6. ¿Qué es el plan estratégico de comunicación interna?}

Saló (2007) lo define como una secuencia de etapas que comprenden: el diagnóstico, diseño, ejecución y control de las acciones de comunicación.

El plan estratégico de comunicación interna, que se abrevia con las siglas PECI, es una hoja de ruta que contiene políticas, estrategias, planes anuales de acción predefinidos y que deben revisarse y actualizarse acorde a las tendencias.

Como hoja de ruta, el PECI es una guía que, para Martín (2011:104), nos "permite saber hacia dónde nos dirigimos, por qué, cómo y en qué momento, sin olvidar que hay que coordinar todos los pasos, acciones y fases a realizar". 
El PECI sirve para explicar a la plantilla hacia dónde se quiere ir y cómo se llegará. Se redacta con la aportación y en consenso con el área de comunicación externa, recursos humanos y marketing.

Es la contribución más significativa del comunicador interno en el cual se trabaja con un calendario de ejecución, además de incluir un mapa de audiencias internas, mensajes claves y temáticas a comunicar para conseguir la ansiada cultura colaborativa.

Siguiendo a Saló (2007), el plan estratégico de una organización es único y responde a los retos de una entidad; en el mismo se proponen planes anuales de acción alineados a la estrategia global de la empresa en un lapso de 3 a 5 años.

Este plan estratégico debe revisarse y adaptarse anualmente, aconseja Vicuña (2003). Debe ir en coherencia con el plan estratégico de comunicación y acorde con la estrategia del negocio, el cual, según Vicuña (2003:25), "recoge las decisiones estratégicas corporativas, en referencia a lo que hará en los tres próximos años para lograr una empresa competitiva".

\section{Rentabilidad del plan estratégico de comunicación interna}

El plan estratégico de comunicación interna es rentable por muchas razones, quizá las más evidentes son que alinea al personal con los objetivos y estrategias del negocio; favorece la transformación digital y mejora el nivel de participación interna; promueve la colaboración y, en consecuencia, mejora la cuenta de resultados de la entidad.

Además, su rentabilidad queda explícita porque permite anticiparnos al futuro, evitando caer en la inercia. De esta manera, la empresa reduce la incertidumbre del qué hacer. 
Basándonos en las reflexiones realizadas por Vicuña (2003), respecto a la importancia de diseñar un plan estratégico para cualquier negocio, deducimos que el plan de comunicación interna también podría servir para:

1. Enmarcar todas las decisiones y acciones de comunicación interna dentro de un proyecto.

2. Recordar a las audiencias internas los valores, la misión y visión empresarial

3. Difundir los objetivos a largo plazo, definir funciones $y$ responsabilidades a niveles clave

4. Coordinar las comunicaciones internas entre áreas

5. Permitir el seguimiento y revisión continuada de las acciones emprendidas

6. Difundir un proyecto de futuro ilusionante, sólido y consistente.

El gráfico 3 resume la rentabilidad del plan estratégico de comunicación interna.

Gráfico 3. Rentabilidad del plan estratégico de comunicación interna

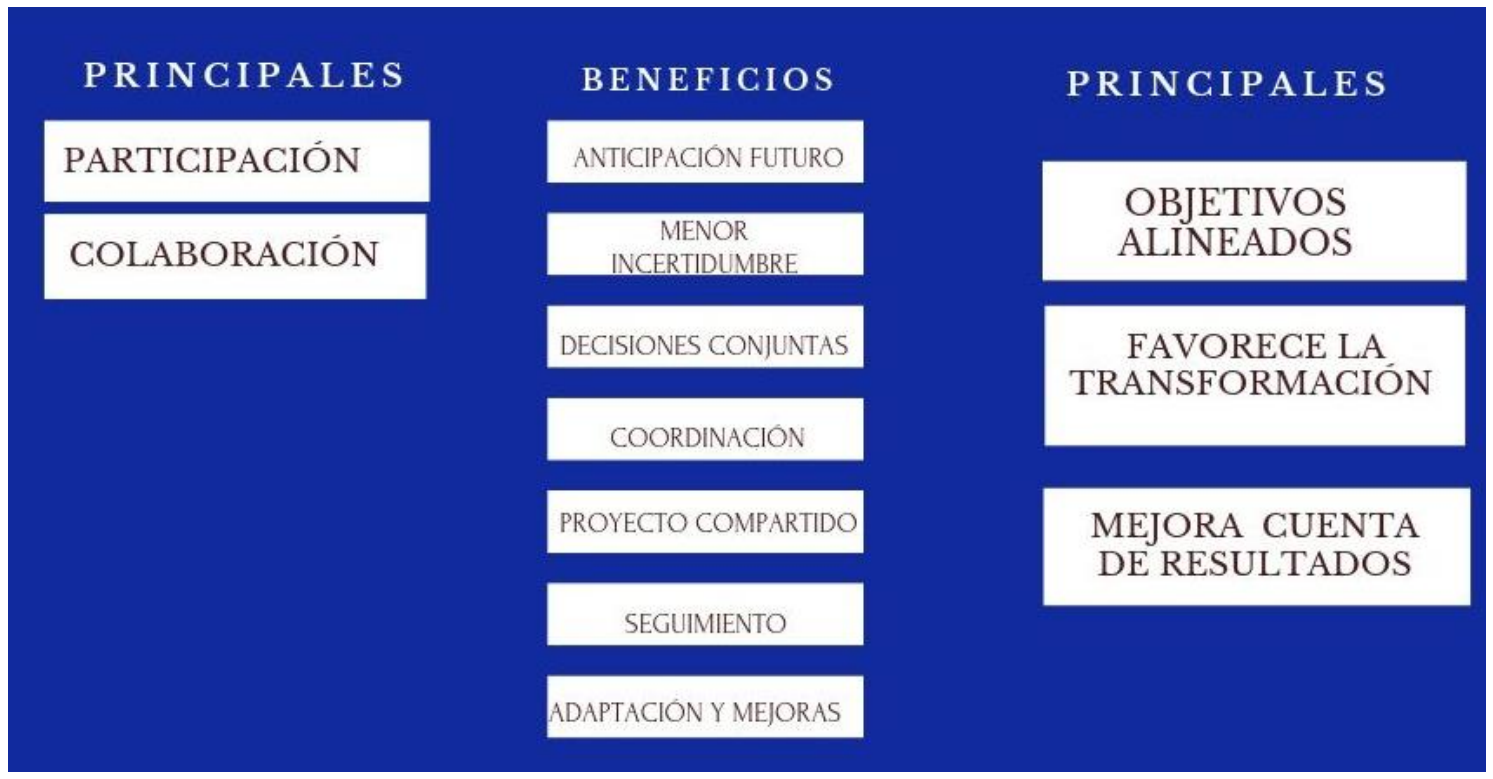

Fuente: Elaboración propia 
Son pues, muchas las razones que lo justifican, sobre todo si consideramos que una empresa es una congregación de personas de diferente generación y únicas; con procedencia cultural diferente.

Estas personas necesitan comunicarse, es decir, interactuar, expresar sus opiniones, desacuerdos, aportar, mejorar y si es preciso, rectificar y aprender.

Cuando una empresa no dedica tiempo a planificar sus procesos de comunicación y mensajes internos, demuestra que no tiene una visión clara y compite sin un proyecto de futuro. Como bien esclarece Vicuña (2003:27), "la planificación permite a las organizaciones participar en la construcción de su propio futuro, evitando quedar a la merced de los avatares del mercado". Indudablemente, aunque no podemos prever el futuro, siguiendo las tendencias es posible anticiparnos a los retos futuros que, en este caso, en materia de comunicación pueden darse dentro de una organización.

De modo que, por las razones expuestas, podemos concluir que el plan estratégico de comunicación interna es una inversión necesaria y altamente rentable para cualquier organización.

\section{El responsable del plan estratégico de comunicación interna}

Es necesario que el plan estratégico de comunicación interna sea delegado a profesionales especialistas encargados de su diseño, ejecución, control y optimización.

En la práctica, la tendencia es que el responsable del PECI comparta despacho con el Director de Comunicación y en algunos casos, este profesional asume la responsabilidad de la planificación de la comunicación tanto interna como externa. Saló (2007) subraya que la 
contribución de estos profesionales es estratégica y necesaria en tanto permiten la gestión del cambio, y de la reputación interna.

Así también, lo constata la Asociación de Directivos de Comunicación [Dircom] (2018:150) que testifica la tendencia creciente de las organizaciones y empresas en asignar presupuestos, recursos humanos y logísticos para la implementación de departamentos de comunicación que ocupan una posición de staff. "El Dircom en la mayoría de los casos (51.8\%), está por delante de la Dirección General (29.2\%). Gran parte de estos profesionales despachan con el CEO". Añade la Asociación que, la estrategia global de la comunicación es una tarea clave en estos profesionales, quienes gestionan tanto la comunicación y la reputación interna como la externa [Dircom] (2018). Estos profesionales trabajan con todos los stakeholders incluidos los internos, a fin de promover y gestionar la mejor imagen interna y externa.

Es así como, los Dircom y los responsables de comunicación interna, se consolidan como los dinamizadores del diálogo interno, como los garantes de las interacciones, siempre alineados con la estrategia del negocio.

Se comprueba así, que la comunicación interna se posiciona dentro del Departamento de Comunicación y su gestión será cada vez más importante, según las conclusiones sobre el Estado de la Comunicación en España [Dircom] (2018:134), "la comunicación interna se posiciona como una función estratégica, necesaria para gestionar el cambio". Quedaron lejanos los 90, años en que la comunicación interna estuvo vinculada básicamente con recursos humanos, formación, marketing, entre otros, (Andreu 1990). 


\section{El plan estratégico de comunicación interna contiene planes y proyectos}

El plan estratégico de comunicación interna para Saló (2007) se proyecta a largo plazo y se concreta a partir de políticas de comunicación interna, planes anuales de comunicación y de sus correspondientes programas puntuales.

La elaboración del plan estratégico es un proceso laborioso, minucioso y visionario que requiere del diseño de políticas y de estrategias. Además, está conformado por un conglomerado de programas, proyectos y acciones aisladas de comunicación interna. Estas acciones suelen ser reuniones informales o eventos breves convocados puntualmente. El cuadro 4 ilustra la magnitud de un plan estratégico implementado con un conjunto de programas y proyectos.

Los programas son claves ya que contribuyen a que comunicación interna cristalice sus metas. Cada programa da cabida y se desarrolla mediante diferentes proyectos. Por su parte, los proyectos se ejecutan a través de acciones y/o actividades.

\section{Gráfico 4 Magnitud del plan estratégico}

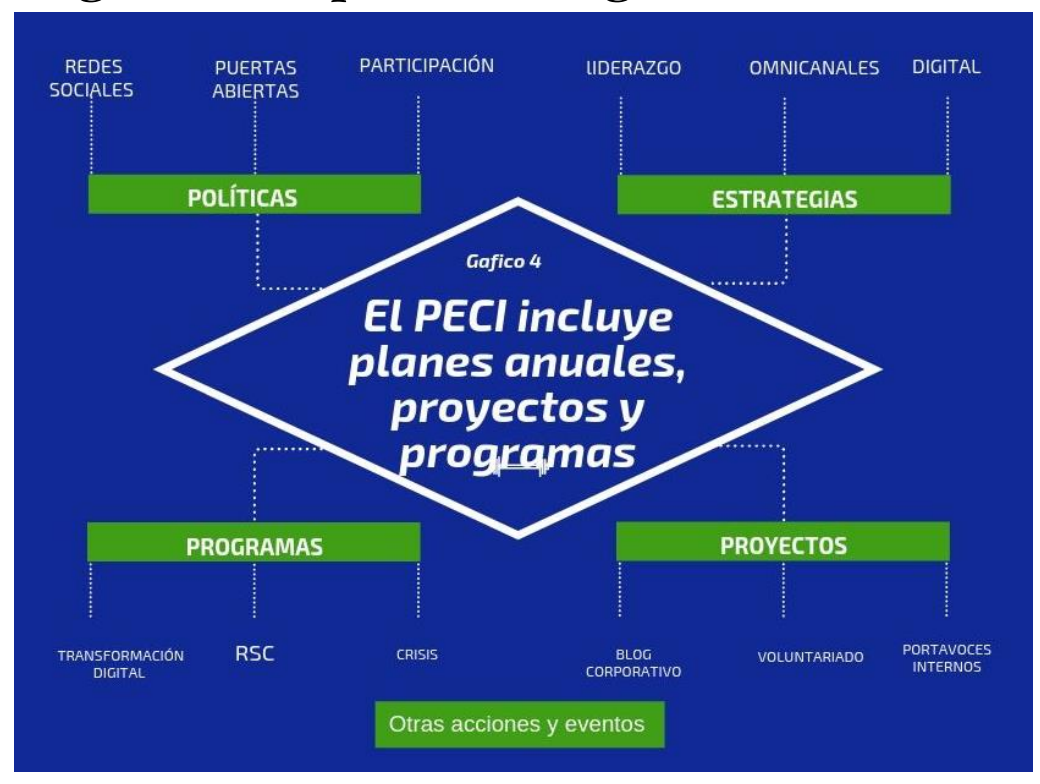

Fuente: Elaboración propia 
Un programa, para Roberts (2012:45), “es un instrumento para coordinar, implementar y hacer progresar la estrategia de la organización". Los programas están enfocados a un ámbito amplio y suelen estar compuestos por un conjunto de proyectos. Así, por ejemplo, un plan estratégico de comunicación interna tiene un programa llamado: digitalización del negocio y se trata de un programa alineado al plan estratégico que contempla la transformación digital del negocio. Este programa incluye seis proyectos: procesos del negocio, blogs, wikis, redes sociales internas, big data y bots.

Como explica Paul Roberts (2012), todo proyecto tiene una fecha de inicio y de fin. Cada proyecto es único, cumple calendarios, maneja un presupuesto autónomo y recurre a un abanico de recursos y expertos Los proyectos tienen una duración más corta y por lo general pocos promotores; se formulan para alcanzar los objetivos del programa.

\section{Conclusiones}

La digitalización creciente de empresas y las comunicaciones digitales siguen otorgando valor a la comunicación estratégica que se posiciona como determinante para alinear al personal con los objetivos y seguir avanzando en la transformación de la organización.

La transformación digital de la empresa no solo es sobre tecnología, sino que abarca además la gestión del talento y la comunicación interna. Si la organización pretende sacar ventaja de la digitalización es necesario que forme y diseñe acciones de comunicación interna.

Gestionar la comunicación interna estratégica dentro de la empresa desde un plan estratégico de comunicación interna (PECI) es decisivo para que una organización sea competitiva y se adapte a las nuevas 
tendencias que marcan las nuevas tecnologías y la nueva era de la inteligencia artificial.

El plan estratégico de comunicación interna (PECI) es un documento personalizado, que debe estar alineado a la estrategia global de la empresa. Dicho plan comprende programas y proyectos; debe ser evaluado y estar sujeto a revisiones y actualizaciones periódicas. El PECI es la contribución más importante y decisiva del comunicador interno. Permite avanzar en la transformación digital, involucra a todo el personal en los cambios y convierte a los colaboradores internos en aliados estratégicos.

\section{Referencias bibliográficas}

Andreu Pinillos, A. (1990). I Estudio del Estado de la Comunicación Interna, Madrid: Instituto de Empresa

Argenti, A. P. (2014). Comunicación Estratégica y su contribución a la reputación. Madrid: LID Editorial.

Asociación de Directivos de Comunicación (2016). Anuario de Comunicación. Madrid: Dircom

Asociación de Directivos de Comunicación (2017). Estado de la Comunicación en España. Quinta Edición. Madrid: Dircom Asociación de Directivos de Comunicación (2018). Anuario de Comunicación. Madrid: Dircom

Cees B. M., Van Riel (2012) Alinear para ganar. Madrid: Lid Editorial. González Hermoso de Mendoza, A. (2001). La Innovación factor clave de competitividad de las empresas. Madrid: CEIM-CEO

Leal, S. (2018). Inteligencia Artificial ¿Nuestro reto u oportunidad? En Anuario de la Comunicación. Madrid: Dircom

Polo, F. (2016). La transformación digital, una necesidad ineludible para las empresas en Anuario de la Comunicación. Madrid: Dircom

Roberts, P. (2008). Gestión de Proyectos. Barcelona: Gestión 2000.

Sainz de Vicuña, J. M., (2003). El plan estratégico en la práctica. Madrid: Esic

Saló, N. (2005). Aprender a comunicarse en las organizaciones. Barcelona: Paidós. 
Tarrés Monserrat (2018) Una profesión en permanente cambio en Anuario de la Comunicación. Madrid: Dircom

Zapata Palacios, L. (2016). Industria de la Comunicación y economía digital: guia básica del DIRCOM. Barcelona: UOC

P\&G (2019). Mejora a través de la Responsabilidad Social 32. Recuperado de https://es.pg.com/es-ES/sostenibilidad-en-png/historiasrecientes-de-sostenibilidad

Mira Agulló, J. G.; Peña Acuña, B. \& Parra Meroño, M. C. (2016). La imagen del CEO: estrategia de comunicación corporativa. Opción [en línea] 2016, 32. Recuperado de http:/ / www.redalyc.org/articulo.oa?id=31048901013 ISSN 1012-1587

Martín Martín, F. (2011). El plan estratégico de comunicación como nuevo modelo de investigación científica universitaria. Recuperado de http://ojs.correspondenciasyanalisis.com/index.php/Journalcy a/article/view/273/250

Accenture (2016). Technology Vision 2016, las personas primer. [en línea]. Recuperado de https://www.accenture.com/es-es/insighttechnology-trends-2016

Roland Berger (2016) España 4.0 El reto de la transformación digital en la economia Informe de investigación [en línea]. Recuperado de https://w5.siemens.com/spain/web/es/estudiodigitalizacion/ Documents/Estudio_Digitalizacion_Espana40_Siemens.pdf 



\title{
De la comunicación interna al diálogo organizacional
}

\author{
Mónica Abendaño \\ Universidad Técnica Particular de Loja \\ Laura Sánchez. \\ Universidad Técnica Particular de Loja
}

\begin{abstract}
PARA CITAR: Abendaño, M., \& Sánchez, L. (2020). De la comunicación interna al diálogo organizacional. En Puertas-Hidalgo, R., Abendaño, M. \& Valdiviezo-Abad, C. (Eds.), (2020). Comunicar: de la táctica a la estrategia. Cuadernos Artesanos de Comunicación, n¹78 (pp.47-60). La Laguna (Tenerife).
\end{abstract}

\section{Resumen}

Según el Instituto Nacional de Estadísticas y Censos del Ecuador, en su informe 2012, señala que, en la ciudad de Loja, Ecuador, existen 4532 empresas de diversa actividad económica. Soto (2015), mediante una investigación, indica que en el Ecuador las empresas privadas invierten la mayor parte de su presupuesto en el desarrollo de sitios web y social media, y apenas el 7\% en acciones comunicación interna; siendo esto una debilidad para la gestión de la comunicación en las organizaciones y para el compromiso institucional.

Frente a ello, si hablamos de organización, no podemos dejar de lado a la comunicación interna, dirigida a todos sus colaboradores, volviéndose una de las partes más importantes por la calidad de información que podemos encontrar, misma que bien canalizada refleja un cambio. La comunicación interna evoluciona positivamente, como lo menciona Costa (2003:131) en su libro Imagen Corporativa del 
Siglo XXI, señala que, en 1980, las empresas españolas dedicaban un $5 \%$ a esta actividad. Un 15\% en 1990 y se prevé un 25\% para el 2000.

Palabras claves: comunicación interna, comunicación organizacional, relaciones públicas, organización.

\section{Un nuevo modelo de comunicación interna: la conversación organizacional}

L

A TRILOGÍA de la responsabilidad de la comunicación interna, de la que habla Michael Ritter (2008), en su libro Comunicación Organizacional, liga estrechamente a la Dirección General, al Departamento de Recursos Humanos y al de Comunicación, quienes definen las políticas y estrategias, aunque estas no sean suficientes para lograr el éxito de la comunicación interna.

El gran paso de la 'comunicación corporativa' es hacia la 'conversación organizacional' y el cambio de mentalidad de algunos empresarios al evolucionar el modelo de comunicación interna al fortalecimiento del liderazgo e involucramiento del recurso humano, mejorando el compromiso de los trabajadores y el modelo de gestión de la empresa.

La comunicación interna es la comunicación dirigida al cliente interno, es decir, al colaborador, entonces escuchar a los públicos al interior de una empresa es importante para saber qué piensan y cuáles son sus necesidades laborales y hasta personales; pues las empresas serían más eficaces y con personas más felices trabajando en ellas, si le apostasen a su humanización.

Novartis, grupo suizo líder en investigación y desarrollo de medicamentos, desde el 2006 cuenta con un observatorio de comunicación interna, en donde los responsables de cada área, identifican las demandas de los empleados e implementan exhaustivas 
estrategias apoyadas por diferentes iniciativas y herramientas. Así, aseguran un verdadero intercambio de información y la participación del personal en todos los procesos, con sentido de pertenencia.

DHL en Chile, creó el DHL e-Xpress integrado por un e-newsletter y un podcast con archivos de audio y video de corto tiempo, en los cuatro idiomas de las oficinas de la región: inglés, castellano, portugués y francés, lo que les permite escuchar la información de la empresa mientras trabajan o en cualquier lugar o momento desde un dispositivo portátil.

Todos buscan mecanismos para llegar a los colaboradores y mantenerlos informados y comunicados, sin embargo, no es suficiente si el esfuerzo de los directivos no se encamina hacia el diálogo. Enrique Dans, profesor de Sistemas de Información en IE Business School sostiene que "todo es conversación".

El primer punto de las 95 conclusiones del manifiesto 'Cluetrain' (el tren de las pistas), dice que los mercados son conversaciones, es decir, invitan a las empresas a participar en un diálogo abierto, claro y espontáneo, con las características de una conversación y de un nuevo e innovador ambiente de mercado.

\section{E1 DirCom interno}

Hay que reconocer que en toda organización existe comunicación, aunque no precisamente tenga un departamento de comunicación o un profesional de la rama que desempeñe profesionalmente sus funciones en el ámbito interno. Entonces, ¿por qué ocuparse de algo que siempre funcionó sin que nadie hiciese esfuerzo?, pues, aunque los directivos ya tienen ocupaciones se debe señalar que el entorno ha cambiado, en la actualidad son las organizaciones las que deben adaptarse al medio y tomar como factor "relevante" a la comunicación interna y a cómo se 
sienten sus colaboradores, pues el aumento de la productividad, la expansión de mercados y demás factores comerciales se pueden ver afectados por el estado interno de la organización y su capital humano.

En Europa se empieza a hablar de la figura del DirCom a mediados de los 90, con un concepto erróneo por la falta de conocimiento de sus funciones, luego se habla de una inflexión, cuando la figura del técnico pasó a la de coordinador de mensajes y finalmente a la del estratega, como se la concibe ahora.

El comunicador español Joan Costa (2010:84), lleva varios años analizando el rol específico de los directores de comunicación en las empresas e instituciones. Su afirmación es rotunda y clara: "el Dircom es un estratega, generalista y polivalente". Como estratega es más que un relacionista con su público, es el gestor de la marca y la imagen, responsable de las acciones significativas de la empresa. Generalista, con visión global se enfoca en la totalidad de las actividades empresariales, desarrollando el pensamiento en cadena; y polivalente, con distintas capacidades, funciones y responsabilidades para afrontar diferentes escenarios.

El DirCom no es un 'lobo solitario'. Su carácter integrador y constructivo y su espíritu de equipo le acompaña siempre, y en ese aspecto positivo se funda su liderazgo (Costa, 2018:51).

Según la posición del Dircom en el organigrama, en relación con el área institucional, corresponde al nivel superior de la empresa, lo cual significa que su función abarca más del $80 \%$ de su tiempo y, por ende, se centraliza aquí la definición de las políticas y estrategias de comunicación integrales, es decir, las relaciones, la reputación, incluyendo no solo la Responsabilidad Social Empresarial -RSE si no también la ética, y el desarrollo corporativo hacia el incremento de la productividad junto con la potencialización del talento humano. 
Uno de los autores contemporáneos como lo es Capriotti (2009:39), en su libro Branding Corporativo, presenta el concepto de comunicación interna como "el conjunto de mensajes y acciones de comunicación elaboradas de forma consciente y voluntaria para relacionarse con los públicos de la organización, con el fin de comunicar con ellos de forma creativa y diferenciada sobre las características de la organización, sobre sus productos y/o servicios y sobre sus actividades". En este sentido, como el director de orquesta se encarga de coordinar los distintos instrumentos que la componen, para que la melodía suene a la perfección, así mismo lo hace el DirCom Interno, cubre las necesidades de comunicación que presentan los colaboradores o grupos que conforman la organización: informar, motivar y comprometer a los implicados en la estructura organizacional.

\subsection{Sus cualidades}

Las cualidades son esenciales para complementar su perfil con otros aspectos de su formación profesional.

Gráfico 1. Cualidades del DirCom Interno en Ecuador

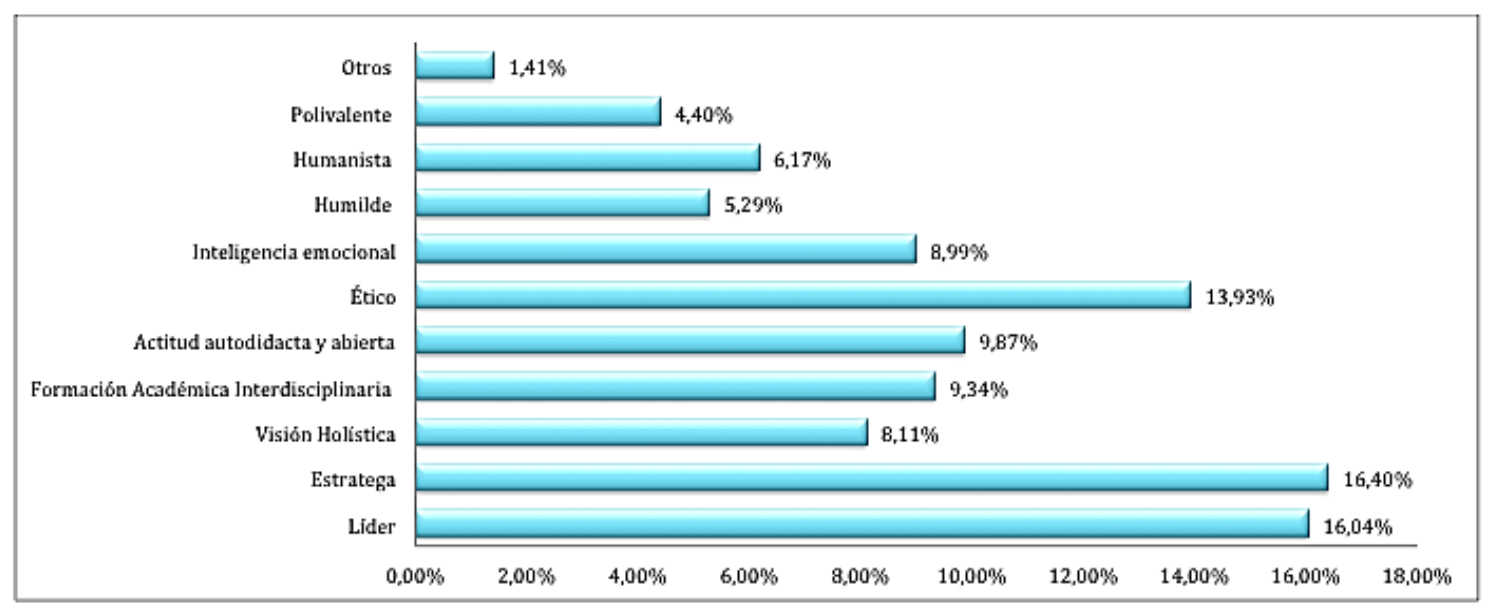

Fuente: Abendaño y Duque (2016)

Y dentro de una organización se requiere de un líder que visione clara, coherente y creíblemente, así lo corroboran los resultados de la 
investigación realizada en Ecuador por Abendaño y Duque (2016), que otorga el $16,04 \%$ a esta cualidad y el $16,40 \%$ a la tarea de ser estratega, como gestor de la marca y de la imagen.

\subsection{Sus funciones}

De la misma investigación Abendaño y Duque (2016), el 22,58\% considera que una de las principales funciones que el DirCom Interno debe desempeñar es el de diseñar políticas de comunicación y para asegurar una eficiente gestión, es importante definir una política, que regule, norme y marque un camino, de lo contrario, esta carencia puede incidir en el clima organizacional, generando insatisfacción en los colaboradores, quienes se sienten excluidos de cualquier situación.

Gráfico 2. Funciones del DirCom Interno en Ecuador

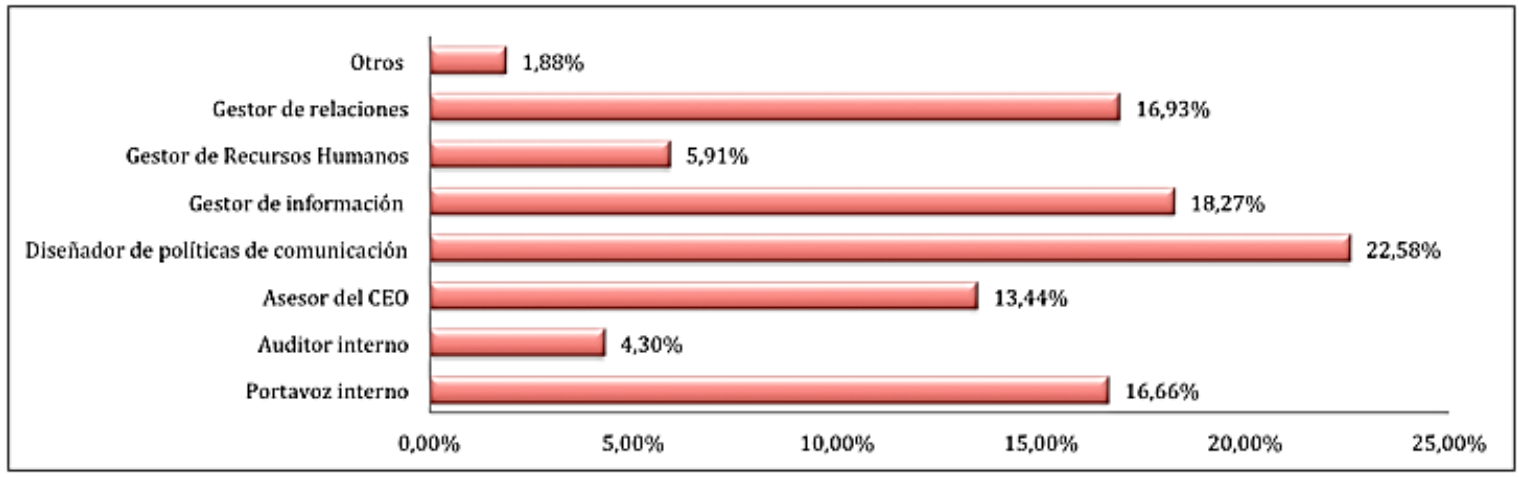

Fuente: Abendaño y Duque (2016)

Además, con la política se puede determinar el compromiso con los valores que establece la organización, como la transparencia, participación, respeto, veracidad, diligencia y colaboración, pues lo ideal es que todos se encaminen hacia la misión y visión establecida.

\section{Herramientas en la gestión de la comunicación interna}

Cada profesión tiene sus propias herramientas de trabajo, y en el caso de la comunicación son todos aquellos elementos que se utilizan para comunicarse con sus públicos, con grupos u otras organizaciones. 
Existen herramientas tecnológicas que ayudan a la conversación organizacional en poca o gran medida. Es el caso del correo electrónico, que hoy en día es la herramienta de comunicación más utilizada a nivel corporativo, que permite la distribución masiva de información, sin embargo, limita las posibilidades de debate y participación, por ello no siempre es tan eficaz.

Si lo único que se pretende es que se lean los mensajes, el correo electrónico puede dar ese resultado en óptimas condiciones, si de informar se trata, pero no asegura que dicha información sea ni recibida, ni leída, ni comprendida, ni compartida por todos.

Otras herramientas, como: manual de bienvenida, revista interna, publicaciones segmentadas, boletines electrónicos, intranet, cartas, circulares, memos, actas, buzón de comunicaciones, tablones, folletos, posters, cartelería, reuniones, encuestas de actitud, videoconferencias, redes sociales, blogs, podcast, entre otros que ayudan a efectivizar la comunicación dentro de las organizaciones, enlazando las funciones de todos los departamentos, con el fin de alcanzar diálogos productivos.

La intranet corporativa, como red interna, privada o de uso exclusivo, utilizada por empresas, tienen gran valor como repositorio documental, convirtiéndose en un factor determinante para conseguir el objetivo de oficina sin papel. Esta red puede alojar la agenda del empleado, directorio telefónico/email, información interactiva de beneficios, encuestas.

María Fernanda Benalcázar, coordinadora corporativa de comunicación del Consorcio Nobis en Ecuador, comenta que Yammer ha permitido integrar a los colaboradores de las empresas del consorcio. Además, por ser una red social interna empresarial, ha contribuido en el trabajo colaborativo, permitiendo consolidar sinergias entre las áreas y las empresas. Asimismo, eliminar el uso 
indiscriminado del correo electrónico (Benalcázar, 2019).

El blog interno de comunicación es una herramienta de colaboración asincrónica, que permite que el empleado pueda expresar ideas y poner contenidos a disposición de otros en la web, de una manera sencilla, el usuario se mueve en un espacio colaborativo y sobre todo interactivo.

Además, están algunas soluciones de Google, como Google Docs, Google Calendar, Google Reader, entre otras. Por ejemplo, Google Calendar, agenda y calendario electrónico, permite sincronizar con los contactos de Gmail para invitar y compartir eventos.

Las redes sociales también colaboran, lideran, motivan y reflejan la productividad del empleado, aumentando el éxito de la innovación. Es importante seleccionar la tecnología adecuada, si el entorno es similar al de redes abiertas como Facebook, Twitter o Instagram, ya que cada una tiene su filosofía y usabilidad.

La presencia de las organizaciones en los diferentes medios sociales es fundamental. Las redes generalistas, como Facebook, Google+ y Twitter, permiten acercarse al público objetivo de una manera amigable y consiguen transmitir el mensaje, pero, principalmente, generar viralidad. Mientras que, las redes para compartir vídeo e imágenes, como YouTube, Pinterest, Flickr e Instagram, se convierten en un repositorio de material promocional a la vez que divulgan las campañas publicitarias (Altamirano y Altamirano, 2018).

En la heurística de Kurt Lewin, psicólogo alemán, el comportamiento es visto como una función de la persona y el medioambiente, y nos comportamos de forma distinta en grupo e individualmente, por ello las redes sociales son un contexto para el comportamiento corresponsable. 
Se debe comprender el cambio como un paso necesario y adoptar una nueva forma de relación al interior de la empresa, con espíritu 2.0, caracterizado por la participación y la retroalimentación, que, como resultado inmediato, se valore el sentido de pertenencia del recurso humano, el mejor activo de toda organización.

\section{Canales de gestión de la comunicación interna en las organizaciones, caso ciudad de Loja}

En las organizaciones es primordial el uso de herramientas para gestionar la comunicación con su público interno, estas permiten desarrollar capacidades de diálogo, de discusión y debate, de interacción y comunicación y, en general de información. Estos van desde canales más tradicionales a las nuevas formas de interacción con los públicos en formato digital.

Gráfico 3. Canales de gestión de la C.I. en las organizaciones de Loja

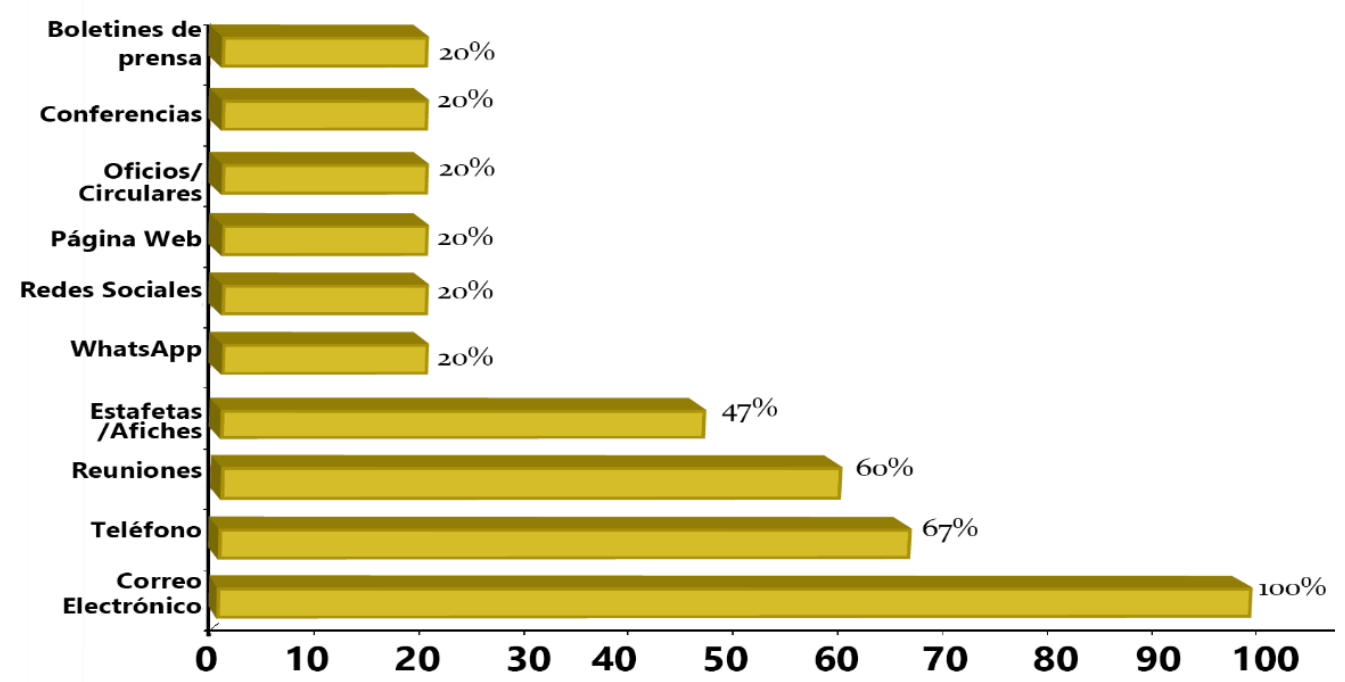

Fuente: elaboración propia

Según los datos, las organizaciones optan por el uso del correo electrónico como primera opción, y respecto de la adaptación a estas nuevas tecnologías para adaptarse al mundo globalizado, que implica el deambular por un espacio mixto donde el código oral y el código 
escrito se intercalan virtualmente en la comunicación humana, lo que sucede en una organización que elige conectar a su público interno.

El segundo canal usado es la red telefónica y como tercera opción recurren a las reuniones, que ofrecen la posibilidad del cara a cara entre colaboradores y mandos superiores, y que a propósito Alejandra Brandolini y Martín González Frígoli (2009), hacen referencia a canales tradicionales "es decir que la criticidad del mensaje nos indica la necesidad de recurrir al cara a cara (mayor complejidad mayor cercanía)". Su uso es recomendable por la formalidad y seriedad, donde el mirarse a los ojos, estrecharse la mano, el tono de la voz y la intención de lo que se comunica, cobra vital importancia y más en esta era de la virtualización.

\section{Política de comunicación interna}

Insistentemente se habla de la importancia de la comunicación en las organizaciones, sin embargo, se descuida el amparo de esa gestión comunicacional, como algo que debe darse solo, sin imaginarse que puede ser como un juego de dados, una cuestión de suerte si es que sacó el número mayor.

El adoptar nuevas y mejores formas de comunicación interna, en relación a la misión, visión, principios y valores institucionales, es importante decisión a través de una política de comunicación a través de normas que guíen esa actuación.

Esta política debe tener como objetivo, coordinar la comunicación puertas adentro y administrar los recursos comunicacionales bajo las siguientes premisas:

1. La entrega de información oportuna al público interno

2. La conversación organizacional 
3. La motivación y sentido de pertenencia dentro de la institución

La política al ser una estructura con normas y reglas que permiten establecer técnicas y estrategias de comunicación, para que la organización pueda trasmitir información adecuada hacia el público interno o colaboradores, también cuenta con claves para que sea elaborada:

1. Segmentación de públicos

2. Delimitar canal adecuado para cada uno de los públicos

3. Identificación de mensajes clave

\section{Responsabilidad social y comunicación interna}

¿Se puede ser responsable sin conciencia? Es imposible, pues debe haber una conciencia individual y si se trata de una organización, ésta debe ser colectiva y qué mejor darle ese trabajo a la comunicación interna, que dentro de su accionar genere este estado de concientización hacia la responsabilidad social.

La conciencia es el medio para que la empresa sea responsable y ser responsable es cumplir las promesas de valor ofrecidas. La conciencia debe ir de la mano con la responsabilidad, de lo contrario no habría compromiso, solo cumplimiento, evitando conseguir un impacto social, es ahí en donde el DirCom interno genera acciones que lleven al trabajador al compromiso, entregando a la organización un trabajo consciente, es decir, que lleve su marca personal, en donde sea notorio la satisfacción que nace en el ser humano al realizar lo que le gusta.

Las empresas deben gestionar acciones de responsabilidad social desde su interior, mejorando el bienestar de los colaboradores y trabajando en su involucramiento, es cuando recién empiezan a ser socialmente responsables, cuando se preocupan primero de su propia gente. 
¿Qué acción puntual de comunicación interna es apropiada para crear conciencia en torno a la responsabilidad social empresarial? Una de ellas, acercar e involucrar a colaboradores al entorno, además de mostrar necesidades y oportunidades. Otra acción, contar con canales de comunicación que garanticen un diálogo transparente, fluido y honesto, reflejando valores institucionales. Generar debates, escuchar sus voces y crear espacios que permitan vivenciar lo que se comunica como responsabilidad social.

¿Cómo diferenciar una campaña de responsabilidad social con una de comunicación interna? Son diferentes, pero se complementan, se interrelacionan. La comunicación interna empodera el plan de responsabilidad social empresarial, desde allí parte la diferencia, además del espacio que se le da a cada una.

Para lograr el objetivo de ser una empresa sustentable a largo plazo, hay que involucrar a los colaboradores, con estrategias y acciones de comunicación interna, evitando acciones sueltas y sin direccionamiento, siendo la planificación la solución más idónea. Las empresas que hacen responsabilidad social y no lo comunican internamente, están perdiendo una gran oportunidad de fidelizar a sus colaboradores.

La responsabilidad social ha dejado de ser una opción, para convertirse en un modelo de gestión empresarial, que ayuda a mantenerse en el mercado, un modelo que implica dirección, valores, comunicación, procesos y medición.

\section{Referencias bibliográficas}

Abendaño, M. y Duque, V. (2016). El perfil del DirCom Interno en el Ecuador. Conference: II Simposio de la Red Internacional de 
Investigación de Gestión de la Comunicación, At Quito Ecuador.

Altamirano, V. y Altamirano, F. (2018). Recursos para la gestión y comunicación online. Cuadernos Artesanos de Comunicación. Sociedad Latina de Comunicación Social.

Álvarez, A. (2011). Medición y Evaluación en Comunicación. Instituto de Investigación en Relaciones Públicas y Comunicación: España. Andrade, H. (2005). Comunicación Organizacional interna. Proceso, Disciplina y Técnica. España: Gesbiblo, S.L.

Argenti, P. (2014). Comunicación estratégica y su contribución a la reputación.

España: Biblioteca Corporate Exellence de LID Editorial Empresarial. S.L.

Erceruelo, B. (2014). Nueva Comunicación Interna en la Empresa. Madrid, España: Estudio de Comunicación, S.A.

Brandolini A., y González Frígoli M. (2009). Comunicación Interna:

Claves para una gestión exitosa. Argentina: La Crujía.

Cáceres, S. (2016). Comunicación Interna: Pilar de la estrategia organizacional. Universidad de Chile: ICEI.

Capriotti, P. (2009). Branding Corporativo. Santiago de Chile:

Colección Libros de la Empresa.

Costa, J. (2010). El Dircom hoy; Dirección y gestión de la comunicación en la nueva economía. Barcelona, España: Gráfic. Granollers Barcelona.

Costa, J. (2003). Imagen Corporativa en el siglo XXI. Buenos Aires: La crujía.

Costa, J. (2018). DirCom, El Ejecutivo Estratega Global. Barcelona: CPC Editor.

Domínguez, D. (2010). La cara interna de la Comunicación en la empresa. Madrid: Visión Libros.

Formanchuk, A. (2010). Comunicación Interna 2.0: un desafío cultural. Buenos Aires, Argentina: Edición Formanchuk \& Asociados. Formanchuk, A. (2011). Branding Interno: una trama inteligente. Buenos Aires, Argentina: Edición Formanchuk \& Asociados.

Minguez, M. (2010). Los públicos en las relaciones públicas. Barcelona, España: UOC.

Islas, O. (2008). Relaciones Públicas. La eficacia de la influencia. Madrid: Gráficas Dehon.

Ritter, M. (2008). Cultura organizacional. Argentina: La Crujía. 
Soto, J. (2015). Gestión de la comunicación digital en las organizaciones privadas del Ecuador: usos y retos. (Tesis de pregrado). Universidad Técnica Particular de Loja, Ecuador.

Túñez, M. (2012). La gestión de la comunicación en las organizaciones. Sevilla: Pedro J. Crespo, Estudio de Diseño Editorial.

Villafañe, J. (2006). Quiero trabajar aqui: las seis claves de la reputación interna. Madrid, España: Pearson/Prentice Hall.

Wilcox, D; Cameron, G. \& Xifra, J. (2006). Relaciones Públicas; Estrategias y Tácticas. Madrid (España): Pearson Educación, S.A.

Xifra, J. (2007). Técnicas de las Relaciones Públicas. Barcelona (España): I.N Ediciones.

Xifra, J. \& Lalueza, F. (2009). Casos de relaciones públicas y comunicación corporativa. Madrid (España): Pearson Educación, S.A.

\subsection{Otros documentos}

Benalcázar, M. (2019). Comunicación personal, 15 de marzo de 2019. Villalba, J. (2012). Mi modelo de comunicación interna. Recuperado el 12 de enero de 2016, de http://goo.gl/M8S7jL

Zapata, L. (2014). Claves para acertar en el liderazgo y Gestión de la Comunicación Interna. Gestionar la comunicación interna. Recuperado el 20 de enero de 2016 de http://goo.gl/1uKnJp

Zapata, L. (22 de enero de 2016). Talentos Reunidos [en línea]. Recuperado de http:/ / talentosreunidos.com/2011/09/28/funciones-de-lacomunicacion-interna/ 


\title{
Transformación digital frente al rol del comunicador interno
}

\author{
Rosario Puertas-Hidalgo \\ Universidad Técnica Particular de Loja \\ Cesibel Valdiviezo-Abad \\ Universidad Técnica Particular de Loja \\ Universidad de Santiago de Compostela - España
}

\begin{abstract}
PARA CITAR: Puertas-Hidalgo, R. \& Valdiviezo-Abad, C. (2020). Transformación digital frente al rol del comunicador interno. En Puertas-Hidalgo, R., Abendaño, M. \& Valdiviezo-Abad, C. (Eds.), (2020). Comunicar: de la táctica a la estrategia. Cuadernos Artesanos de Comunicación, nº178 (pp. 61-79). La Laguna (Tenerife).
\end{abstract}

\section{Resumen}

Las organizaciones deben adaptarse al nuevo contexto que propone la cuarta revolución industrial y sus transformaciones. En este sentido, la comunicación es la clave, permite a las organizaciones evolucionar y sostenerse en el tiempo. Principalmente, una comunicación interna que debe ser priorizada para fortalecer la relación con los públicos, promover la imagen institucional, la reputación, la sostenibilidad y muchísimos factores más. Aparece entonces también, el comunicador interno, con un rol clave y estratégico en este proceso de transformación que debe contar no solo con las habilidades requeridas para su desempeño, sino también con el conocimiento para contribuir al cambio cultural de la organización. En este capítulo se analizarán el rol del comunicador interno y sus aportes al cambio cultural de las organizaciones en momentos de transformación tecnológica. 
Palabras claves: comunicador interno, comunicación estratégica, comunicación digital, organización.

\section{Convergencia digital de la comunicación interna}

T A COMUNICACIÓN es un intangible primordial de la $\mathcal{L}$ organización, donde las relaciones personales y sociales constituyen un sistema de comunicación básico apoyado en canales efectivos. La gestión de la comunicación, afirma Castillo (2010), abarca a la globalidad de la organización, que tiene una función asesora y que debe participar en la estructuración, seguimiento, y aplicación comunicativa de otras acciones elaboradas desde y para la organización.

Gestionar la comunicación representa un reto para las organizaciones, por un lado, la comunicación formal que se establece a través de fuentes o canales oficiales, $y$, por otro lado, la comunicación informal que es la comunicación interpersonal que se genera a base de ruidos y que también existe en las organizaciones.

Las nuevas tecnologías han traído a la sociedad una evolución de plataformas y recursos para comunicarse y ha hecho que los públicos sean más exigentes a la hora de digerir información.

Los entornos digitales plantean un desafío para los comunicadores, debido a la gran cantidad de información que se produce, es por esto que para sobre vivir en estos entornos, como afirma García Almaguer (2017), los comunicadores deben:

1. Tener buen manejo de métricas, analíticas y estadísticas, ya que una meta que se puede medir se puede alcanzar. 
2. Conocer cómo viralizar historias, ya que el contenido debe circular para aumentar su alcance de manera exponencial y llegar a la mayor cantidad de individuos posible.

3. Construir la narrativa correcta para ser pertinentes y creíbles, con historias basadas en una estructura y una lógica de pensamiento que permita seguir una línea específica.

En estos últimos años, producto de la evolución de estas tecnologías, se habla mucho de convergencia digital, que integra contenidos que se elaboran desde diferentes formatos, que procesa y transporta información de forma eficaz y eficiente a través de plataformas virtuales. Uno de los atributos más relevantes de la convergencia digital, de acuerdo con Serrano, Rainiero, Martínez y Garibay (2010), es propiciar y estimular el trabajo colaborativo.

La convergencia digital ha marcado una cultura en la sociedad, donde los actores buscan interrelacionarse de manera frecuente e inmediata. $Y$ en el sector empresarial sucede igual, una empresa que no comunica, no existe, por ende, las organizaciones buscan nuevas estrategias para mantener informados a sus públicos internos y externos y las tecnologías son un buen aliado de una comunicación asertiva, porque converge audio, texto, video o imágenes que se comparten con facilidad y permiten que el impacto sea inmediato.

Las empresas deben asumir el reto de adaptar y usar las tecnologías en beneficio de ellas mismas, afirman López y Fernández (2007).

Actualmente, es necesaria e indispensable la incorporación de Internet y software apropiados a la gestión interna para el adecuado desarrollo de los procesos de negocios, lo que mejoraría la productividad y eficiencia de quienes hacen la organización. Paralelo a ello, los desarrollos tecnológicos obligan a las empresas a adaptar su estructura o forma de comunicar, debido a la cultura digital de la sociedad, donde los públicos 
demandan obtener información oportuna y los empleados buscan relacionarse con los diferentes mandos o departamentos. Implantando la necesidad desde la empresa por crear medios o canales digitales a fin de interactuar y compartir contenido completo, llamativo e inmediato desde una fuente oficial y confiable.

Los objetivos organizacionales de una empresa, considera González (2005), no deben limitarse en atraer o desarrollar el talento de sus empleados, sino también intentar que los conocimientos y talentos permanezcan el máximo tiempo en la organización. Esta fidelización se puede lograr al seguir una estrategia de comunicación apoyada en las tecnologías introducida en el entorno empresarial.

En el diccionario de la Real Academia Española, se define a la convergencia cuando dos líneas tienden a "unirse en un punto". Salaverría (2009) al hablar de convergencia lo define en cinco palabras, la convergencia es un proceso. Actualmente, estamos sometidos a este proceso donde todos vemos grandes cambios, ya sea en dispositivos y en contenidos, aportes que pueden venir desde diferentes sitios pero que recaen en un solo lugar para poder visibilizarse. La convergencia puede entenderse como esa evolución en el ámbito tecnológico, empresarial, de contenidos y en la labor profesional.

Entonces hablamos de una convergencia en el campo de la comunicación interna, donde el profesional de la comunicación tiene que atender a públicos más exigentes.

Los contenidos que llegan hacia los públicos se vuelven cada vez más personalizados. El conocer las preferencias y gustos, hace posible llegar con mensajes oportunos y con las características adecuadas de los productos comunicacionales. Hay que considerar también, que los públicos internos, gracias a las nuevas tecnologías se han convertido en 
generadores de contenidos gracias a la gran cantidad de aplicaciones actualmente disponibles en el mercado.

La convergencia profesional requiere y exige que los profesionales estén al día conociendo a sus públicos. Es necesario lograr sinergia entre quien está al frente de la comunicación interna y los públicos que pertenecen a la organización.

Cada vez más aparecen nuevos canales de comunicación y empresas que ofrecen estos servicios de manera especializada. Quienes hacen comunicación interna deben proponerse hacer comunicación de forma dinámica e interactiva que permita atraer la atención a los públicos.

La convergencia nos obliga a cambiar los formatos, los soportes, los canales, pero la esencia de los contenidos y los mensajes debe estar siempre apegado a la visión institucional, esa es una clave del comunicar en tiempos de convergencia. Estos cambios han llegado impactar también en nuevas formas de hacer comunicación, desde el periodismo (Túñez-López, Toural-Bran y Valdiviezo-Abad: 2019) como la comunicación estratégica.

\section{Comunicación y comunicador interno}

Las organizaciones que aún cuentan con sistemas de comunicación tradicionales y se resisten a incorporar tecnología en sus procesos de comunicaciones, deben necesariamente dejarse apoyar por estas nuevas herramientas, que brindan muchas potencialidades al equipo de comunicación y a la organización.

El Internet se ha convertido en un espacio donde todos queremos estar, para satisfacer necesidades de información y entretenimiento. Los canales y herramientas de comunicación virtuales, para Ortiz González (2010:84) “se vuelven progresivamente más poderosos y 
eficaces para cultivar y mantener las relaciones con los públicos objetivos", considerando que no son solo las personas quienes emplean estos espacios, si no las empresas de manera formal.

Con el aparecimiento y despegue de la tecnología también aparecen nuevos retos para la comunicación y el comunicador, donde para este último, se pone en evidencia no solo sus conocimientos adquiridos durante su formación académica, sino también otras competencias y destrezas como: en su campo profesional u otras áreas que aporten a su formación y contribuyan al manejo de ordenadores, la elocuencia, resolución de problemas, aprendizajes autónomos desenvolvimiento eficiente y eficaz de sus actividades dentro de la organización.

Al considerar la comunicación como uno de los ejes centrales en la organización, se vislumbra un efecto rebote que se provoca automáticamente en beneficio de la misma organización.

La comunicación es importante en y para la organización; pero es más importante aún, la comunicación interna, que se ha convertido en la palanca que aporta en tiempos de transformación y consolidación de la cultura organizacional de los colaboradores. La comunicación interna es la esencia de la organización y estratégicamente bien desarrollada se evidenciará a todos los públicos de la institución.

Esta transformación digital, en palabras de Túñez (2012:73), beneficia a la organización ya que los públicos internos son los portavoces con credibilidad externa e interna, favorecen a mejorar el clima laboral y se proyecta al incremento de la productividad. Lo primero que se debe considerar en una organización son los colaboradores y desde ahí se debería empezar a cuidar al público externo y esa pudiera convertirse en la regla de oro para las organizaciones. 
El actuar de la comunicación interna, manifiesta Arizcuren (2008), debe regirse al plan estratégico, la cultura y los objetivos de la organización para reflejar la imagen de la empresa. Para que esto se dé, se requiere una implicación de todos los niveles de la organización en el proceso de comunicación. Pero también es necesario que las estrategias y acciones de comunicación interna se ajusten a las líneas básicas del plan de comunicación de la organización y las nuevas formas de trabajo que fruto de la tecnología surgen.

El comunicador debe asumir el reto de gestionar el cambio desde una comunicación interna tradicional a una comunicación digital sin perder el horizonte de la organización, sus principios, sus valores, su misión y visión.

En este momento, para las empresas el contar con un comunicador que gestione la comunicación interna es estratégico, ya que esta comunicación bien gestionada aporta valiosos beneficios a la organización, entre ellos: genera vínculos entre los públicos y los altos mandos, conoce de cerca el estado de la comunicación interna y plantea soluciones donde varias dependencias pueden ser parte de las soluciones, conecta personas y promueve el flujo de información, propone un plan de comunicación interno, identifica entre los mismos empleados influencers para juntos promover un mejor clima laboral, entre otras.

Es un desafío para el responsable de comunicación interna ejercer su labor que implica generar prácticas y promover hábitos que van más allá de reconfigurar la cultura organizacional. Lograr que el público interno entienda y apoye las decisiones institucionales que fomentan la sostenibilidad de la organización y su permanencia en el mercado, que es cada vez más competitivo, es también un reto para este profesional. Por tanto, su función se convierte en la de evangelizar los cambios que 
se viven dentro de la institución y mostrar todas las potencialidades que tiene la empresa frente a todas las circunstancias.

El profesional de la comunicación interna, de acuerdo con Serrano (como se citó en Martínez-Méndez y Zermeño-Espinosa, 2018:740):

No puede pretender solamente permanecer con los conocimientos iniciales, esos que obtuvo el estudiante en la universidad, sino que deberá empaparse del entorno, de [una] diversidad de temas que no necesariamente serán de comunicación, sino de todas las disciplinas donde un comunicador tenga entrada a laborar, puede ser desde el campo de la salud, la ingeniería y el gobierno, entre otras.

Por tanto, el comunicador interno debe ser cada vez más competitivo y productivo. Debe estar al día en el manejo de las nuevas tecnologías y conocer de cerca todas las potencialidades que estas traen. Considerando que, el consumo de Internet va en aumento y quienes lo hacen atienden una diversidad de necesidades de información y comunicación.

El comunicador interno, explica Zapata Palacio y Gómez Quijano (2016:559), sigue consolidándose y evolucionando. Actualmente, desempeña en varios roles:

1. Rol movilizador: que llama a la conversación y a la participación a los colaboradores.

2. Rol integrador: apuesta por la participación y el conocimiento compartido para alinear a los colaboradores con los objetivos del negocio.

En una entrevista realizada a Noskin Ostrowiak (como se citó en Palacios, 2014:9), investigador en el campo de la comunicación organizacional, expresa que "un comunicador es un articulador, pues 
en una organización las personas tienen muchas cosas que compartir y decirse entre las diferentes áreas y especialidades y en los diferentes niveles; el comunicador debe ser el articulador de esas dinámicas y ayudar a que exista el diálogo".

El comunicador interno, en el siglo XXI, también cumple un trabajo clave a nivel jerárquico con los directivos de la empresa, ya que entre algunas de las labores que hace es asesorar sobre marca personal, toma de decisiones y entre otras.

Al ritmo de la revolución industrial y tecnológica, el comunicador interno se fusiona con otras áreas de la institución para hacer un trabajo 360 en equipo y lograr mejores resultados. Dependencias como Recursos Humanos, Marketing, Publicidad son de las más frecuentes.

Este trabajo estratégico se puede realizar empleando una diversidad de herramientas de alto impacto, como los canales de escucha (estudios de clima interno, auditorías de comunicación interna), canales digitales (redes sociales, blogs, foros...) y audiovisuales (videos, podcast...) (Zapata Palacio \& Gómez Quijano, 2016:558).

El comunicador interno debe generar valor agregado y de crecimiento para la organización; por tanto, sus conocimientos y habilidades son sus claves de gestión para su desenvolvimiento profesional y el logro de resultados en su ámbito de actuación.

Para el comunicador interno, la convergencia es una evolución tecnológica con un gran potencial de recursos que le brinda las herramientas y los insumos para comunicar mejor los mensajes y llegar de manera correcta y en el momento oportuno a los públicos.

Si se habla de comunicación multimedia, también se habla de un comunicador multimedia, donde este profesional con todo su 
conocimiento puede explotar la información de diversas maneras y con ello, construir una variada cantidad de recursos para lograr una comunicación dinámica e interactiva.

El comunicador, considera Moscol \& Gamero (2013:127) que, "desempeña un rol de gestor importante negociando soluciones mutuamente beneficiosas para la construcción, mantenimiento y defensa de las relaciones con los públicos". El rol de los profesionales de la comunicación interna, debe ser apoyar a las instituciones para hacerles vislumbrar con claridad la posición actual, su rumbo a seguir y la meta a la que quieren llegar (Llano Prieto, 1998:267).

Nos cabe entonces pensar que, el comunicador interno debe ser como un emprendedor, salir a buscar oportunidades, a encontrar soluciones a problemas existentes, a pensar de manera creativa lo que se podría resolver tradicionalmente o simplemente actuar de una manera distinta para encontrar en la comunicación oportunidades de mejora, crecimiento, empoderamiento y resultados positivos.

\section{Rol del comunicador interno}

Las organizaciones deben trabajar en una comunicación interna efectiva que motive y comprometa a los públicos internos hacer equipo para alcanzar los objetivos institucionales.

En este sentido, la comunicación interna tiene cuatro funciones principales (Scott \& Mitchell, 1976; Robbins \& Judge, 2009:351-352, como se citó en Túñez, 2012): control, motivación, expresión emocional e información.

1. Control: mecanismo de control del funcionamiento de la organización para evitar el caos, como aval de un correcto funcionamiento y como alerta de situaciones 
2. Motivación: ingrediente fundamental de la productividad y el buen funcionamiento de una organización al explicar al trabajador el modo de mejorar la forma de hacer las cosas o corregirlo, hacerle comprender qué y cómo se hace, y hacerle saber lo que está haciendo bien.

3. Expresión emocional: los entornos organizativos son el principal escenario de interacción social, y por tanto el entorno habitual de satisfacción de las necesidades sociales.

4. Información: circular información que los individuos o grupos necesitan evaluar las alternativas posibles y para tomar decisiones (Túñez, 2012:74-75).

Funciones que deben adaptarse a los públicos de manera permanente e ir reintegrándose a las actividades diarias incluso con los efectos de internet y sus transformaciones tecnológicas, que plantean siempre nuevos retos y provocan cambios que han modificado completamente la forma de comunicarnos entre personas y desde las organizaciones hacia sus diferentes públicos internos y externos.

Por tanto, los perfiles de los profesionales de la comunicación también cambian. Bermeo (2010) habla del término full-stack, para referirse al aparecimiento de los profesionales generalistas, donde manifiesta que nadie puede saberlo todo, sobre todo, pero los profesionales deberían poder visualizar lo que sucede en todos los entornos para que su trabajo resulte de alto rendimiento y optimización, y en el caso del desarrollo de una aplicación informática el profesional debería ser capaz de ver lo que sucede en todas las capas, tanto superior como inferior.

En el campo cambiante de la comunicación digital, también se han hecho necesarios este tipo de perfiles profesionales que combinen el ámbito técnico y humano, o el lado "cliente y la infraestructura" y que se complementen entre sí para ofrecer los distintos servicios de alto 
nivel (Jiménez-Gómez \& Mañas-Viniegra, 2018:241) y donde incluso de se pudiera llegar hacer una combinación de ambos campos de formación y conocimiento.

La gestión de la comunicación interna implica una responsabilidad fuerte en la organización para el profesional que la ejerce. Proteger la cultura organizacional es una demanda de todas las organizaciones; por lo tanto, el comunicador interno que asume este reto lo debe hacer con mucha responsabilidad.

Entorno a esta línea, manifiestan Zapata, Gómez, y Pacheco (2016:2) que "el comunicador interno necesita poseer unos conocimientos específicos, así como unas competencias directivas que garanticen las funciones de: diagnóstico de clima, planificación, ejecución y evaluación de las comunicaciones internas generadas... Su misión principal es liderar el cambio institucional y fomentar el diálogo interno entre la comunidad... El comunicador interno necesita poseer: unos conocimientos propios, competencias de documentación, diagnóstico y comunicación, así como, unas habilidades multimedia y digitales que garanticen el eficaz y eficiente desempeño de sus funciones".

El responsable de comunicación interna tiene como objetivo liderar las comunicaciones internas, fomentando el diálogo interno entre todas las áreas, involucrando a todo el personal a través de comunicación multidireccional y transversal. Esto no quiere decir que se establezca un único flujo de información ni que el mismo mensaje se comparta con todos (Túñez, 2012:86).

Entre algunas de las competencias que se destacan para este profesional, a criterio de Zapata, Gómez, y Pacheco (2016:8-9) se encuentran: 
1. Habilidad para documentarse, esta le permitirá recabar información y seleccionar la pertinente para atender las necesidades comunicativas que se requieran al interior de la organización.

2. Diagnosticar y solucionar problemas, al trabajar internamente esta habilidad podrá darle un valor agregado a su capacidad de atender eventualidades.

3. Detectar necesidades de formación, a través del diálogo o utilizando otros mecanismos, podrá identificar las carencias formativas de la organización y hacer propuestas que solucionen dichas debilidades.

4. Trabajo en equipo y gestión de multidisciplinaria de grupos de profesionales, esta es una habilidad que le permitirá trabajar en el logro de resultados para la institución, además de fortalecer las relaciones en el equipo al hacerlos multidisciplinares.

5. Habilidad para comunicarse, colaborar e implicar, podrá liderar el desarrollo de los planes que a nivel de comunicación interna se proponga. Además, que debe desarrollar la habilidad de la escucha y la observación con los colaboradores.

1. Propuesta y ejecución de campañas integrales, la habilidad y el conocimiento que tiene sobre diversos campos de la comunicación y al aplicarlos el comunicador interno podrá desarrollar campañas integrales con resultados efectivos que involucren la participación de los diferentes públicos.

2. Producción de piezas en diversos formatos, la elaboración de formatos y productos acorde a las exigencias modernas será también un reto para el comunicador interno, donde deberá hacer sus planteamientos para la divulgación de información entorno a estos requerimientos.

3. Evaluación, mantener una permanente evaluación de sus estrategias y productos de comunicación es clave para mejorar la comunicación interna. 
4. Actualización de conocimientos, un comunicador interno debe permanentemente mantener sus conocimientos actualizados y no descuidarse de las tendencias de comunicación.

Las características del perfil del comunicador interno, propuestos por Molina (2016), que se suman a las anteriores, son:

1. Visión estratégica y orientación a resultados: visualizar los objetivos a largo plazo y crear las condiciones necesarias de comunicación para acompañar el proceso.

2. Amplio conocimiento del mercado y de las tendencias: conocer lo que está marcando tendencias para la organización, con el fin de anticiparse a lo que se viene. Así mismo, promueve en los colaboradores altos estándares de productividad, orgullo de pertenencia, alto valor de marca empleadora, y felicidad laboral.

3. Exigencias multigeneracionales: conocer y comprender los aspiraciones y marcos de referencia de las generaciones que conviven en los espacios de trabajo para asegurar la inclusión en el marco comunicación/cultura organizacional. Así como conocer los entornos que provocan estos cambios generacionales.

4. Habilidad para facilitar conversaciones: capacidad para actuar como un business partner de la organización, facilitando herramientas y espacios para el desarrollo eficiente de la conversación al interior de la organización.

5. Comprensión para gestionar cambios: comprender los procesos de cambio que atraviesan las organizaciones para alcanzar su más alto propósito. Debe garantizar el logro de pequeños hitos significativos para el común de los colaboradores, reduciendo los argumentos de resistencia al cambio.

6. A ellas, se suman otras que vemos pertinentes considerar en el entorno actual del ejercicio profesional del comunicador interno 
y de manera especial en el entorno de transformación digital que vivimos:

7. Ser especialista, ser un profesional que cuente con todos los conocimientos y la experiencia para desempeñarse en este cargo de comunicador interno.

8. Tener siempre visión estratégica, conocer enteramente la organización, su visión y objetivos institucionales. Actuar de manera proactiva y en base a los principios institucionales. Se debe pensar en la comunicación de manera integral.

9. Manejar métricas y analíticas, evaluar la eficacia de las estrategias y acciones de comunicación para ajustar o cambiar las que no han funcionado según lo esperado.

10. Actualización permanente, es necesario que esté al día con los temas que maneja la organización para dar respuestas oportunas alineadas a la filosofía institucional y ser también oídos para transmitir esos mensajes a la alta gerencia.

11. Ser generador de contenidos, de acuerdo a los públicos a los que se desea llegar y con los mensajes correctos. Con ello, se puede generar conversaciones en espacios digitales y conectar con los públicos.

12. Tener un perfil multidisciplinar, que domina las ciencias empresariales y la gestión de personas porque trabaja con y para equipos multidisciplinares dentro de la organización.

13. Conocer la empresa y sus proyecciones futuras, es elemental que el comunicador interno tenga profundo conocimiento de la organización en la que colabora y que conozca su planificación futura para poder proyectarla y mostrar los desafíos a los que se proyecta en el futuro. Esto permitirá que los colaboradores interioricen lo que la empresa está queriendo de ellos a futuro y los llevará a comprometerse de manera productiva con la organización.

14. Ser generador de comunicación interpersonal, a través de la comunicación debe lograr un acercamiento con los 
colaboradores de la institución donde se produzca una escucha activa y afectiva.

15. Gestor de contenidos, también es gestor de contenidos a través de los cuales despierta o genera nuevas emociones en los públicos internos y con este tipo de contenidos transmite sentimientos que conecta los colaboradores con la organización.

16. Ser críticos de la realidad, para cambiar o mejorar lo que no se está haciendo bien y proponer hacerlo de mejor forma.

17. Lectores y analíticos de datos, donde con la abrumante cantidad de información se requiere tener el criterio para interpretar la información que nos genera nuestro público interno.

18. Espíritu innovador, para identificar recursos o herramientas tecnológicas vigentes y promover su uso al interior de la organización. Así como también identificar nuevas estrategias de comunicación que vayan más allá de las expectativas de los colaboradores.

19. Comunicar basados en las emociones, generar una comunicación que toque el corazón y la razón de los colaboradores para promover una comunicación efectiva. Las experiencias vividas por cada uno de los colaboradores en su entorno laboral marcadas por las relaciones humanas son un fuerte potencial a aprovechar para una buena comunicación.

Ahora mismo, la formación de los profesionales de la comunicación interna se ha convertido en un reto. Requiere de manera permanente actualización de conocimientos y adaptarse a los procesos de transformación digital y al uso de herramientas tecnológicas que se implementan en las organizaciones.

Lo que marca la diferencia de la comunicación del siglo XX al siglo XXI es que, la comunicación interna ya no es responsabilidad de un área o departamento, es responsabilidad de todos quienes forman parte de la organización. Cada público interno debe tener claro lo que está 
haciendo, por qué se está haciendo y, qué beneficios profesionales, personales y grupales se obtienen del desempeño (Zapata Palacio y Gómez Quijano, 2016:559).

Las empresas no podrán sobrevivir sino desarrollan una capacidad para adaptarse al nuevo contexto que proponen las tecnologías de información y a los hábitos de los nativos digitales.

\section{Conclusiones}

Los comunicadores internos son piezas claves en la gestión de la comunicación y el acercamiento con los públicos internos; por ello, es indispensable su labor en las organizaciones considerando todos los beneficios y ventajas que atraen más allá de la sostenibilidad de la organización.

El asumir el rol de comunicador interno, es posiblemente como muchas profesiones, un reto que implica compromiso, mucha entrega, responsabilidad y amor a la profesión. A ello se suma una formación permanente y autodidacta que le permita actualizar y desarrollar nuevas competencias claves para su trabajo profesional.

\section{Referencias bibliográficas}

Arizcuren, (2008). Guia de buenas prácticas de comunicación interna. Madrid: FEAPS

Castillo, A. (2010). Introducción a las relaciones públicas. España, Málaga:

Instituto de Investigación en Relaciones Públicas.

Ekos Negocios (2016). Revista Ekos presenta: Ranking 1000 Ecuador 2016. Rankings. Negocios. Revista Ekos. Recuperado de

http://www.ekosnegocios.com/negocios/verArticuloContenido.aspx ?idArt=7919

García Almaguer, M. (2017). Crisis Viral. Nuevas Tendencias de Comunicación Política Digital [digital]. Grupo Editorial y de Investigación Polaris S. A. 
González, R. (2005). Nuevas tecnologías aplicadas a la gestión de RRHH: Las TIC como herramientas de mejora permanente para capital humano. España: Vigo

Jiménez-Gómez, I., \& Mañas-Viniegra, L. (2018). Ofertas de empleo mejor remuneradas en comunicación y diseño: nuevos perfiles y efecto fullstack. Doxa Comunicación. Revista Interdisciplinar de Estudios de Comunicación y Ciencias Sociales, (27), 239-251.

Ortiz Gonzáles, J. (2010). El rol del comunicador en la era digital. Revista Interuniversitaria de Formación Del Profesorado, (33), 73-85.

Llano Prieto, S. (1998). El perfil del comunicador organizacional en el mercado de trabajo. In M. A. Rebeil \& C. Ruiz-Sandoval (eds.), El poder de la comunicación en las organizaciones.

López, P. Fernández, J. (2008). Web 2.0 y empresa. Manual de aplicación en entornos corporativos. Asociación Nacional de Empresas de Internet. ANEI

Túñez-López, J. M.; Toural-Bran, C.; Valdiviezo-Abad, C. (2019). Automatización, bots y algoritmos en la redacción de noticias. Impacto y calidad del periodismo artificial. Revista Latina de Comunicación Social, 74, pp. 1411 a 1433.

http://www.revistalatinacs.org/074paper/1391/74es.html DOI: 10.4185/RLCS-2019-1391

Martínez, G. \& Zermeño, M. E. (2017). La comunicación organizacional en México: representaciones sociales desde la mirada del profesional (pp. 99-123). En Arévalo \& Guillén (Coords.). La comunicación para las organizaciones en México: evolución, teoría y práctica. México: Universidad Anáhuac en coedición con Editorial Tirant lo Blanch. ISBN 978-84-17069-08-7

Martínez-Méndez, G., \& Zermeño-Espinosa, M. E. (2018). Academic and professional update in organizational communication: a challenge for AMIPCO. Razón y Palabra, 22(1-100), 727-748. Recuperado de

https://archivos.revistarazonypalabra.org/index.php/ryp/articl e/view/1132

Moscol, R., \& Gamero, R. (2013). Approach to the trust as internal good of Public Relations. Revista de Comunicación, 12(1), 110-138.

Recuperado de http:/ /ezproxy.concytec.gob.pe:2060/ContentServer.asp?'T=P $\& \mathrm{P}=\mathrm{AN} \& \mathrm{~K}=92630502 \& \mathrm{~S}=\mathrm{R} \& \mathrm{D}=\mathrm{a} 9 \mathrm{~h} \&$ EbscoContent $=\mathrm{dGJy}$ 
MNLr40Sep644yOvsOLCmr0yep7BSs664S7eWxWXS\&Conte ntCustomer=dGJyMPGvsEq0rq5MuePfgeyx44Dt6fIA

Molina, S. (12/04/2016). El nuevo perfil del comunicador interno.

Comunicación interna. Desarrollo organizacional. Recuperado de https://mundoci.net/tag/perfil-del-comunicador-interno/

Ortiz Gonzales, J. (2010). El rol del comunicador en la era digital. Revista Interuniversitaria de Formación del Profesorado, (33), 73-85.

Palacios, J. (2014). De la comunicación organizacional a la comunicación productiva: modelo propuesto por Abraham Nosnik Ostrowiak. Razón y Palabra, 87, 1-12.

Salaverria, R. (2009). Los medios de comunicación ante la convergencia digital. [en línea]. Recuperado de

https://dadun.unav.edu/bitstream/10171/5099/1/Ramon_Sal averria.pdf

Serrano, A.; Cabrera, M.; Martínez, E.; \& Garibay, J. (2010).

Digitalización y convergencia global. México: Editorial CONVERGENTE

Túñez, M. (2012). La gestión de la comunicación en las organizaciones.

Comunicación Social Ediciones y Publicaciones. Zamora: España.

Zapata Palacios, L. \& Gómez Quijano, A. (2016). El Comunicador interno, de profesional de la información a profesional de la comunicación (pp.540-562). Comunicracia y Desarrollo Social: Actas del I Congreso Internacional Comunicación y Pensamiento (Rosalba Mancinas-Chávez coord.) Recuperado de https://idus.us.es/xmlui/handle/11441/50623

Zapata, L. F.; Gómez, A. G.; \& Pacheco, M. (2016). Funciones y competencias del comunicador interno institucional universitario. In Congreso Iberomericano PiatCom (pp.1-11). Madrid - España.

\subsection{Otros documentos}

Bermeo, C. (2010). The Full Stack, Part I. Recuperado de https://www.facebook.com/note.php?note_id=461505383919 



\title{
Uso estratégico de medios digitales aplicado a la comunicación interna. Caso COCOA
}

\author{
Gustavo Cusot \\ Universidad San Francisco de Quito \\ Isabel Palacios \\ Universidad San Francisco de Quito
}

PARA CITAR: Cusot, G. \& Palacios, I. (2020). Medios sociales y comunicación interna. Caso COCOA. En Puertas-Hidalgo, R., Abendaño, M. \& Valdiviezo, C. (Eds.), (2020). Comunicar: de la táctica a la estrategia. Cuadernos Artesanos de Comunicación, n¹78 (pp.81-95). La Laguna.

\section{Resumen}

La comunicación interna es indispensable para la transmisión y consolidación de la cultura organizacional, pues a través de ésta se interioriza la filosofía y esencia de una institución en sus públicos. La estrategia adquiere un valor protagónico dentro de esta gestión, pues guía todas las acciones a implementar. Dentro de ésta, es importante considerar la integración de medios sociales digitales, pues dinamiza la comunicación y permite la cuantificación de los resultados obtenidos. Para el desarrollo de una estrategia, es vital realizar previamente un estudio que revele la situación actual de la comunicación, para en base a ello, crear un plan de acción ajustado a las necesidades del momento. Este artículo expone el caso del Colegio de Comunicación y Artes Contemporáneas de la Universidad San Francisco de Quito, el cual, a partir de un estudio de comunicación realizado en el 2017, desarrolla un plan de acción para la gestión de contenido de su cuenta de Facebook, la cual está dirigida a su público interno. 
Palabras claves: comunicación interna, cultura organizacional, medios digitales, gestión de contenido, planificación comunicacional.

\section{Introducción}

L

A IMPORTANCIA de la comunicación dentro del mundo organizacional es cada vez más reconocido y valorizado, ya que no solo apunta a una mayor interacción entre sus miembros y públicos externos, sino que permite el crecimiento y buen desarrollo de la organización, sustentado en estrategias que fortalecen su identidad e imagen institucional. Difícilmente una herramienta de comunicación implementada sin una planificación, podrá cumplir satisfactoriamente su función, ya que será utilizada sin un previo conocimiento de las necesidades de la organización y del perfil de su público objetivo.

Para lograr el cumplimiento de objetivos de una organización a corto, mediano y largo plazo, es indispensable una estrategia comunicacional que guíe y controle cada una de las decisiones y acciones realizadas dentro de la organización. En este sentido, la estrategia comunicacional adquiere gran importancia, pues en ésta, se reúnen las herramientas y planes de acción adecuados para cada organización. Por este motivo, es crucial una programación y organización responsable de la gestión comunicacional, que involucre los canales y herramientas adecuadas según el objetivo planteado, que permita una oportuna transmisión de mensajes, y al mismo tiempo, una activa participación entre los públicos. Ante esta premisa, el entorno de comunicación digital, protagonizada por los medios sociales digitales, es una alternativa que toma posesión cada vez con más evidencia en el planeamiento comunicacional de las organizaciones e instituciones. Precisamente el uso de plataformas virtuales de redes sociales virtuales se ha anclado de manera ideal dentro de la estrategia de comunicación interna del Colegio de Comunicación y Artes contemporáneas (COCOA) de la 
Universidad San Francisco de Quito, la cual ha tenido como desafío el adecuado manejo de la comunicación interna de su cuenta oficial de Facebook, a través de una gestión de contenido específico. Para lograrlo, el COCOA llevó a cabo un estudio publicado en ComInt DirCom (2017) en el cual se revelaron indicadores clave sobre los intereses del público interno, con respecto al contenido de la página. En base a ello, se diseñaron nuevos parámetros y tácticas de gestión de contenido, adaptado al perfil de su comunidad. Cabe mencionar que, a pesar de que la página oficial es abierta, el contenido abarca eventos, premiaciones, entre otras actividades que se evidenciarán en detalle más adelante. Este artículo expone el plan de acción llevado a cabo en su cuenta de Facebook y los resultados cuantitativos que se han obtenido de la página a través de un análisis comparativo 2017-2018.

\section{Desarrollo}

La finalidad de la comunicación interna, sin importar el camino, la estrategia o las herramientas empleadas, está enfocada en cumplir con los objetivos planteados, motivando e involucrando a los públicos internos de la organización a través del intercambio de información; en otras palabras; "hacer partícipes a todos los miembros de la organización de lo que la organización hace, instándoles a colaborar, a sugerir, a comentar; en una palabra: involucrar a todos los miembros de la organización en la comunicación" (Salo, 2000:36). Otro factor importante de la comunicación interna es que, manejada correctamente, crea sentido de pertenencia entre todos sus públicos; y esto a su vez, impacta positivamente en el ambiente organizacional, reforzando la integración de los colaboradores y proyectando ante ellos una imagen favorable de la empresa, organización. (Andrade, 2005).

Mencionado el impacto de la buena comunicación interna en sus públicos, es pertinente señalar el importante rol que esta gestión desempeña en la cultura organizacional, pues ésta se manifiesta en 
todas las áreas de la organización. La cultura "determina la forma como funciona una empresa y se refleja en las estrategias, estructuras y sistemas. Es la fuente invisible donde la visión adquiere su guía de acción” (Rodríguez y Pezo, 2005:55). En este sentido, es indispensable que el manejo de la comunicación interna sea estratégico. Y para ello, la adaptación a la globalización y evolución tecnológica de las herramientas es vital para esta gestión. Es como las organizaciones e instituciones han tenido que dar paso a esta adaptación para poder desenvolverse en un nuevo entorno, el de la tecnología de la comunicación que surgió durante la primera década del siglo XXI, involucra ya la utilización de internet desde computadoras y diversos dispositivos móviles. Como asegura Carretón (2007), las empresas se desenvuelven bajo un entorno "complejo y dinámico y, por consiguiente, deben y tienen que adaptarse si quieren seguir permaneciendo en él" (Carretón, 2007:22). La incorporación de la web 2.0 convirtió al internet en un canal dinámico, en donde los usuarios son actores emisores y generadores de contenido, por lo que desarrollan un papel protagónico en la comunicación. En la web 2.0 los públicos "están en continua interacción y esto es lo que determina el ciclo de la comunicación, siempre y cuando el efecto del mensaje producido en el receptor sea transmitido sin ruidos al emisor para incidir o no en un cambio con respecto al mensaje inicial" (Losada, 2004:47)

Las redes sociales se han convertido en uno de los canales comunicativos más empleados por las organizaciones para generar un vínculo más dinámico de comunicación con sus públicos. "Los medios sociales son ejemplos de la Web 2.0, que contrastan significativamente con las tecnologías top down más pasivas que caracterizaron las páginas de la Web 1.0" (Durango, 2005:9). Así, con la masificación de la Internet y la generalización de utilización de medios sociales, el alto impacto que tiene la comunicación en los públicos es incuestionable. Las organizaciones están cada vez más cerca de sus stakeholders y con 
mayor capacidad de generar un vínculo emocional, incluso antes de que estos se conviertan en sus consumidores. El desafío está en trabajar para que la empresa proyecte en sus públicos confianza y una imagen positiva a través de cada una de las publicaciones e interacciones que genere con ellos. Las principales virtudes que ofrecen las plataformas virtuales, según Castelló (2013:107), son la capacidad de reacción inmediata sobre la imagen organizacional, creación y consolidación de la comunidad o público objetivo, incremento de notoriedad, control sobre la reputación, estrategias de segmentación, personalización de mensajes, capacidad de interacción y de viralización del contenido.

La gestión estratégica de la comunicación del COCOA se adaptó a estos nuevos entornos incorporando canales virtuales en plataformas sociales desde el año 2013, creando su cuenta en Facebook, a través de la cual imparte en su público un sentido de pertenencia y fidelización hacia la facultad de la universidad. Debido a la diversidad de perfiles e intereses de sus públicos, es crucial administrar la gestión de contenidos basada en una previa investigación de su público interno, compuesto en su mayoría por personas de entre 17 y 50 años. Por ello, en el año 2017 se realizó un estudio cuantitativo y cualitativo a través de las siguientes técnicas: una encuesta virtual, con la finalidad de comprender los intereses del público objetivo en cuanto al manejo y generación de contenidos de Facebook. La comunidad que participó en esta encuesta abarcó a alumnos, profesores, graduados y administrativos. Y, por otro lado, se realizaron breves entrevistas presenciales con miembros de la comunidad. Este estudio arrojó inputs y recomendaciones importantes por parte de la comunidad, las cuales se tomaron en cuenta para el desarrollo del plan estratégico de comunicación interna, en Facebook específicamente.

Según el estudio revelado en la revista DirCom (2017), Consultoría en Comunicación, se indicó que "pese a que la página utiliza un tono informal en su contenido, la comunidad demanda aún más 
informalidad. Este dato es muy importante, debido a que marca la distancia o cercanía entre la facultad y audiencia. Con respecto a los temas de interés, se destacan los anuncios a próximos eventos. Sin embargo, se evidencia gran demanda en sorteos y concursos, y publicaciones de proyectos de los alumnos. La mayoría de los encuestados señaló que estos dos últimos temas lograrían que el usuario acceda con más frecuencia a la página del COCOA. Por otro lado, es importante evidenciar la alta preferencia de la comunidad por las publicaciones con fotos, videos y GIFs. Estos formatos atraen visitas, y generan mayor interés" (Cusot, 2017:35).

Con estos resultados, el COCOA diseñó un plan estratégico para la gestión comunicacional interna.

Los objetivos estuvieron enfocados principalmente en crear reconocimiento por parte de la comunidad del COCOA, y lograr que la página de Facebook de la facultad sea la primera herramienta de comunicación a la que acuda la comunidad COCOA tanto para información de la facultad, como de temas similares. Para ello, tomando en cuenta los resultados de la investigación mencionados anteriormente, se realzaron varios ajustes estratégicos de comunicación, los cuales están divididos en tres partes: a) Tácticas generales de contenido, b) Tácticas en cuanto a la comunicación de eventos, y c) Tácticas para la gestión de actividades en días pre establecidos. A continuación, se detalla cada una:

\subsection{Tácticas generales de gestión de contenido:}

Se crearon diferentes hashtags, con diferente temática, los cuales se exponen a continuación: 
1. \#eventoCOCOA: utilizado para la cobertura y difusión de información de eventos, desde su creación hasta detalles de post evento.

2. \#noticiaCOCOA: Se incluye en este segmento artículos, notas, reportajes de cualquier miembro COCOA.

3. \#orgulloCOCOA: Se publicarán aquí cualquier tipo de logro de profesores, alumnos.

4. \#proyectoCOCOA: Se difunden con este hashtag proyectos realizados dentro de la Universidad, concursos, deberes, clases.

5. \#concursoCOCOA: Se incluyen sorteos y concursos que realice el COCOA.

6. \#tipsCOCOA: utilizado para comunicar cualquier información interesante sobre temas del COCOA.

7. \#perfilesCOCOA: se publican los perfiles de la comunidad

8. \#talentoCOCOA: creado para difundir las obras de la comunidad.

En cuanto al leguaje, se estableció utilizar etiquetado en todas las publicaciones que sea posible, con@ antes de cada etiqueta.

Para los diversos eventos del COCOA, se plantearon las siguientes normas:

1. Incorporar el hashtag: \#eventoCOCOA

2. Utilizar la etiqueta: @evento

3. Indicar los detalles del evento y etiquetar el lugar. De ser el caso, exponer información de los expositores, y etiquetar a los mismos.

A continuación, se expone un ejemplo de un anuncio de evento realizado por el COCOA en alianza con la Fundación por una vida, el cual consiste en un agasajo Navideño a más de 150 niños con cáncer. Este evento cuenta varias actividades como shows infantiles, villancicos, manualidades, etc. y se reciben donaciones de cabello. En 
esta actividad se involucran decenas de personas, entre estudiantes, profesores, graduados, entre otros.

Imagen 1. Facebook: publicaciones 15 y 29 de noviembre.

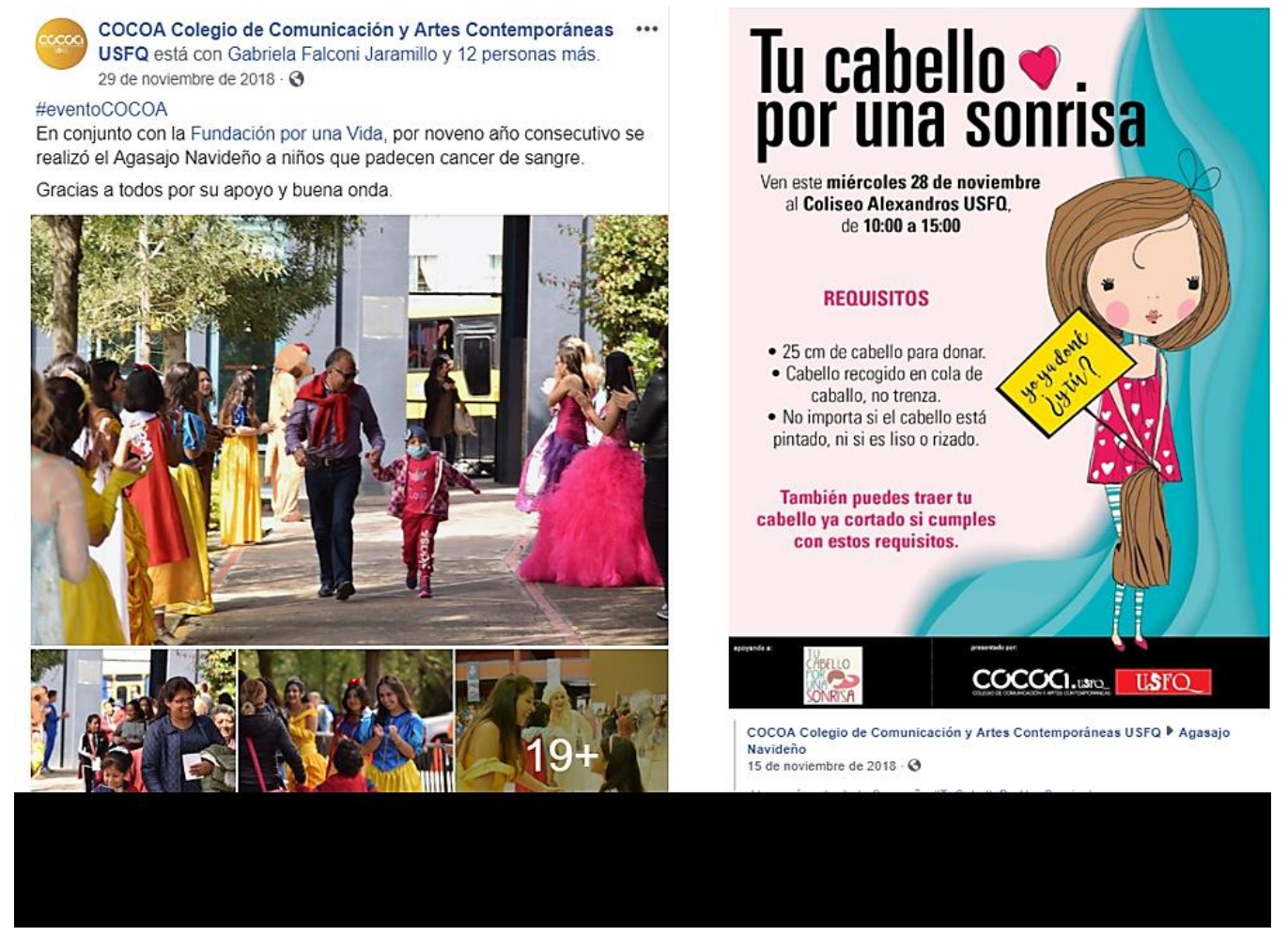

1. En Noticias: incorporar hashtag: \#noticiasCOCOA, \#orgulloCOCOA. Utilizar etiquetado: @alumniusfq, @nombre de la persona, de@carrera a la que pertenece o perteneció, @Medio y hora en el que fue publicado. Incluir enlace que conduzca a la vista previa de la foto de la noticia.

A continuación, se expone un ejemplo de contenido que corresponde este apartado, el cual pone en conocimiento a la comunidad COCOA, la producción de largometrajes animados realizados por la carrera de Animación Digital.

Además, difunde un artículo publicado por el Diario El País "El Cine de Animación Despega en Ecuador", el mismo que protagoniza a la Universidad San Francisco y a la facultad. Esta noticia se expuso con los hashtags mencionados: \#noticiasCOCOA, \#orgulloCOCOA. 
Imagen 2. Facebook: publicaciones 24 y 28 de agosto.
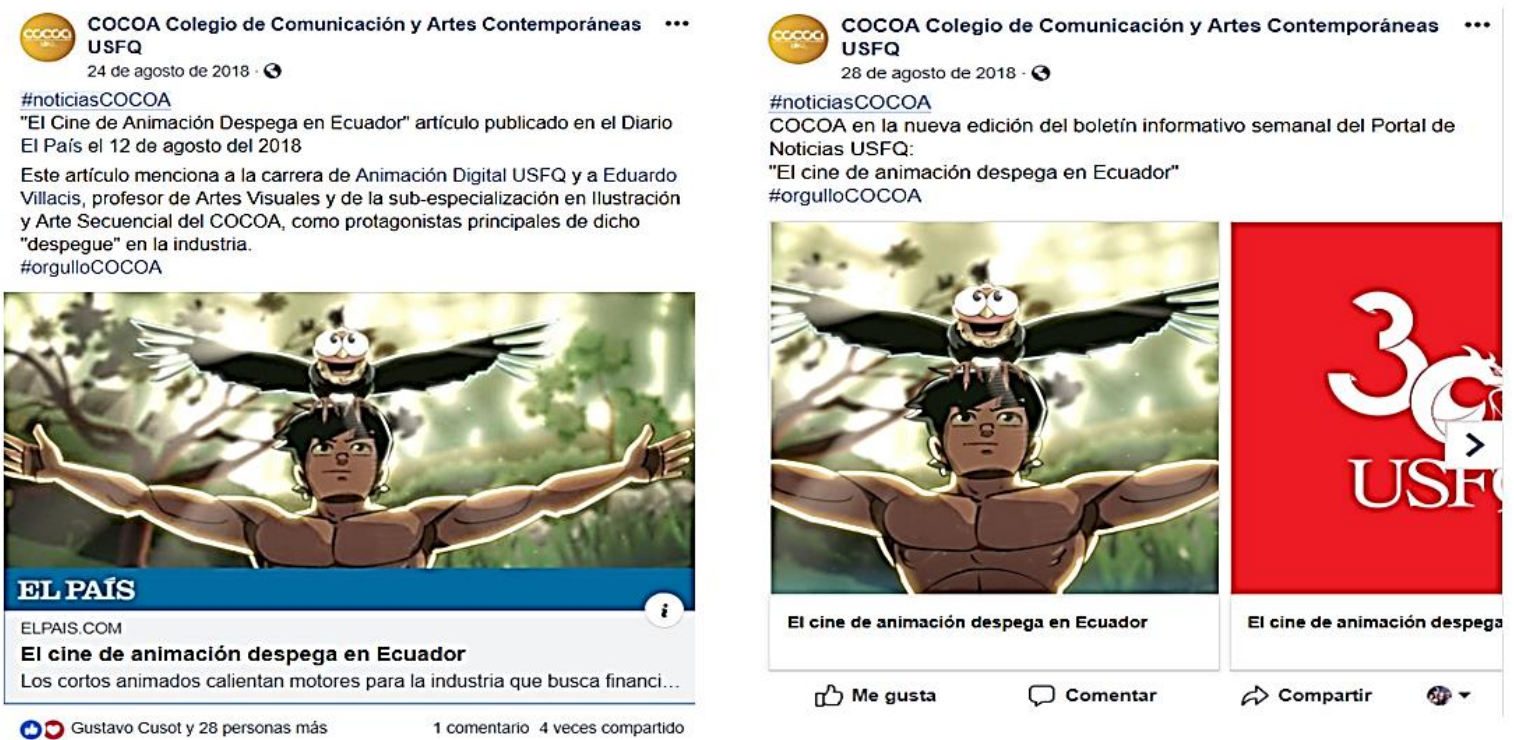
\#orgulloCOCOA

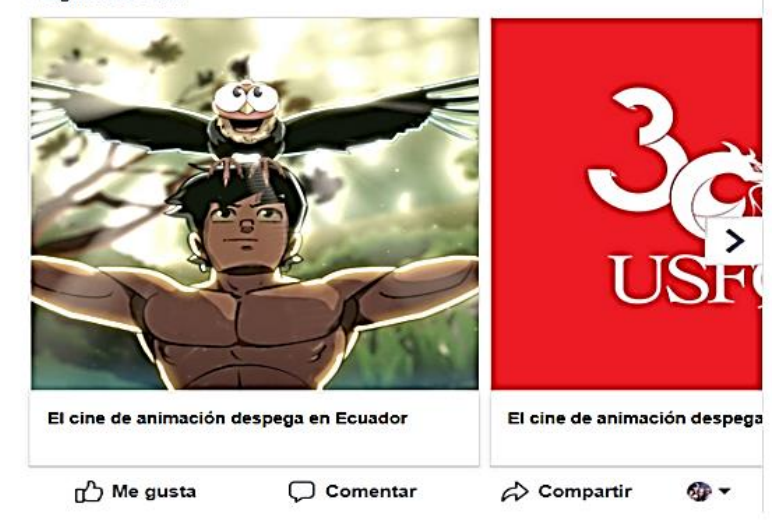

2. En Concursos: introducir el concurso con el hashtag \#concursoCOCOA, exponer las instrucciones del concurso, y detallar el premio para el ganador del concurso. Se exponen a continuación varios de los concursos que realiza el COCOA en el que premia la atención, la participación y el conocimiento de su comunidad.

Imagen 3. Facebook: publicaciones 11 de octubre y 6 de noviembre.
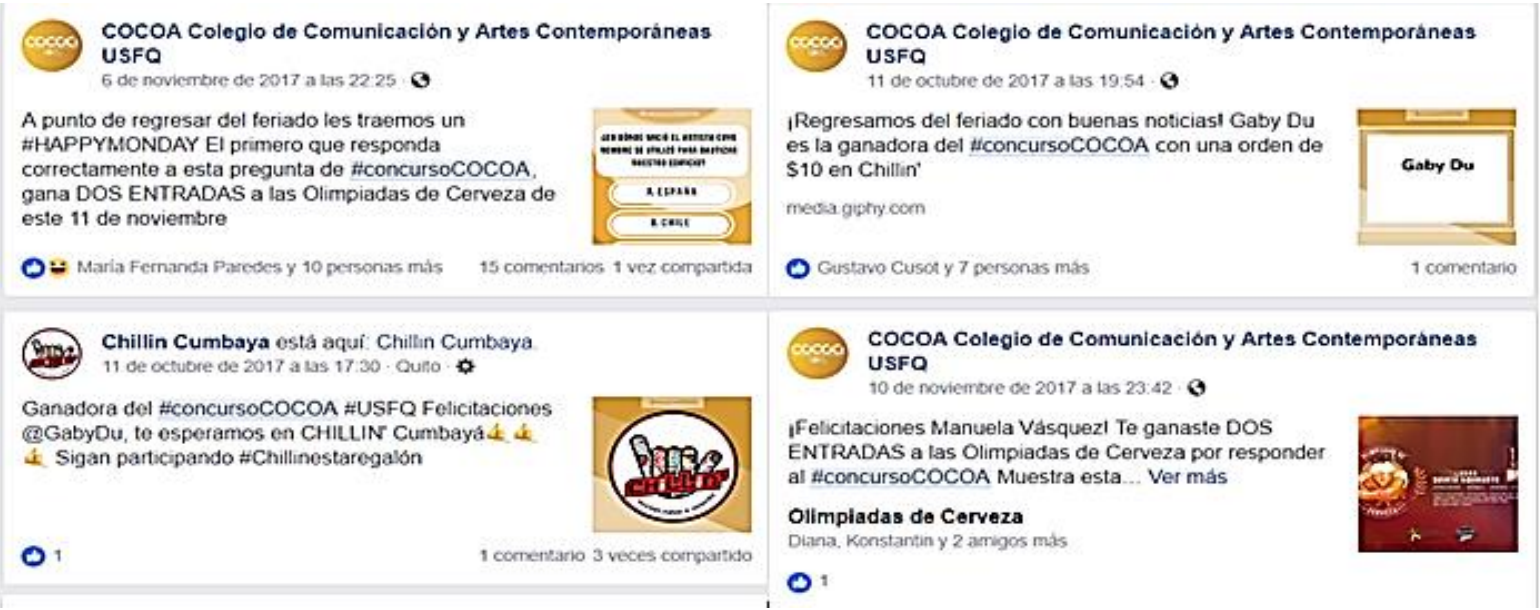
01

3. En Talento: introducir el talento incorporando los: hashtags \#talentoCOCOA y \#orgulloCOCOA 
Utilizar etiquetado para el@artista y su@nombre de la obra o proyecto.

Imagen 4. Facebook: publicación 21 de diciembre.

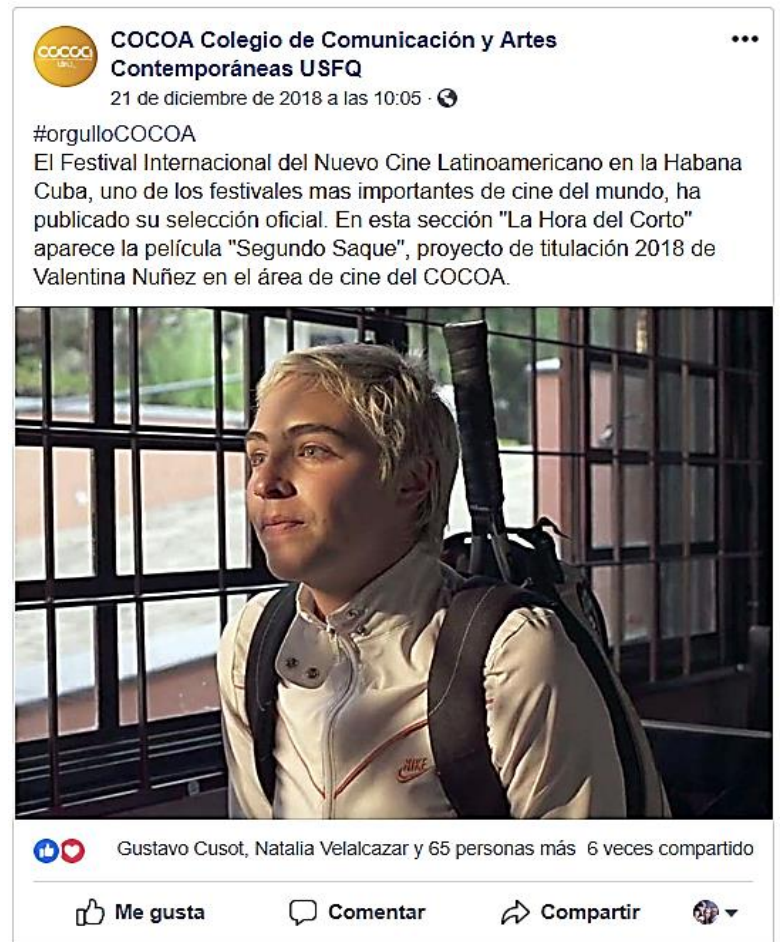

Es este ejemplo, se evidencia la generación de contenido de talento \#orgulloCOCOA con respecto a el anuncio de un cortometraje de ficción "Segundo Saque" producida y dirigida por talentos del COCOA. Dicho cortometraje, se presentó en el Festival Internacional del Nuevo Cine Latinoamericano en la Habana-Cuba.

Tabla 1. Tácticas para la comunicación de eventos.

\begin{tabular}{|l|l|}
\hline Creación & $\begin{array}{l}\text { El evento se debe crear en el Fanpage de Facebook con } \\
\text { antelación evento } \\
\text { Se debe llenar el formulario del evento y enviar } \\
\text { fotografías de este. }\end{array}$ \\
\hline Publicaciones & $\begin{array}{l}\text { Hacer un seguimiento para que se llene completamente } \\
\text { el cronograma de publicaciones }\end{array}$
\end{tabular}




\begin{tabular}{|c|c|}
\hline & $\begin{array}{l}\text { En el caso de que no se envíen el cronograma de } \\
\text { publicaciones, compartir publicaciones del evento o de } \\
\text { páginas que publiquen al respecto. } \\
\text { Realizar un mínimo de dos publicaciones al menos dos } \\
\text { semanas antes } \\
\text { Realizar una publicación una semana antes } \\
\text { Realizar un recordatorio un día antes del evento }\end{array}$ \\
\hline Cobertura & $\begin{array}{l}\text { Se deberá fotografiar el evento: } \\
\text { Personas destacadas (expositores, artistas, decano, } \\
\text { vicedecano, otras autoridades de la universidad) } \\
\text { Sociales } \\
\text { Obras } \\
\text { Evento en general (auditorio) }\end{array}$ \\
\hline Post evento & $\begin{array}{l}\text { Realizar publicación del evento dos días después: } \\
\text { Resumen } \\
\text { fotografías (máximo } 15 \text { dependiendo de la importancia } \\
\text { y el carácter del evento) }\end{array}$ \\
\hline
\end{tabular}

Elaboración propia

\subsection{Tácticas para la comunicación de actividades en días preestablecidos}

1. Lunes de concursos: Seis veces al año (una vez pasando un mes) y dos semanas de publicaciones:

- El primer lunes de cada mes, se postea contenido que motive y alegre a la comunidad.

- El tercer lunes del mes se anuncia al ganador del concurso

2. Martes de talentos: Dos veces al mes y una semana antes del evento, se invita a los alumnos a enviar sus obras al mail del COCOA. Se utiliza como apoyo el mailing masivo. Tres días después se realiza otra publicación de recordatorio, y en el caso de ser necesario, dos días después. 
3. Miércoles de perfiles: Publicación de perfiles de personas destacadas en las áreas del COCOA (profesores; alumnis; alumnos con proyectos interesantes, externos, destacados, ganadores; y personas externas, en el caso de que no contar con un perfil COCO). En la publicación, incluir foto de la persona, breve biografía, enlaces en donde se pueda encontrar (redes sociales, portafolio), breve historia de su trabajo, pequeña muestra de su trabajo.

4. Jueves de eventos y proyectos: Posteo de eventos pasados recientemente, como premios COCOA, Mixturas, etc. Posteo de todos los proyectos ganadores de cada semestre.

5. Viernes de contenido externo: Frases, artículos, libros.

\section{Resultados}

Después de un año de implementación del plan -es importante mencionar que se han llevado a cabo ligeras variaciones en la marchalos resultados conseguidos en la Fanpage de Facebook han sido favorables y apuntan a conseguir las metas planteadas. En el 2017, se cerró con los siguientes resultados obtenidos de manera orgánica:

Tabla 2. Resultados obtenidos de Facebook.

\begin{tabular}{|l|c|c|}
\hline & Media 2017 & Media 2018 \\
\hline Alcance & 140 & 590 \\
\hline Me gusta & 4863 & 5476 \\
\hline Visitas & 242 & 252 \\
\hline
\end{tabular}

Elaboración propia

Como se evidencia en la tabla 2 , haciendo una relación entre los años 2017 y 2018, se evidencia que la media en el alcance de la página ha incrementado un $321.4 \%$, los likes del contenido de la página en un $271.5 \%$ y el número de visitas un 4\%. Con estos datos se evidencia el funcionamiento del plan y su impacto en la evolución de la 
comunicación interna con respecto a la cuenta de Facebook. Sin embargo, como se ha mencionado, es factible y positivo la modificación de una o más tácticas durante el proceso para encaminar la estrategia hacia el cumplimiento de todos los objetivos.

Es importante exponer como ejemplo de manejo de contenido y resultados a uno de los eventos creados en este medio social: Premios COCOA, en donde el Colegio premia a sus estudiantes y graduados destacados, entre ellos, comunicadores, artistas, cineastas, diseñadores; en sus iniciativas o proyectos memorables. Esto con la finalidad de otorgar reconocimiento y fomentar la creatividad y pasión por la carrera. Para difundir este evento, se habilitó la opción para promocionar el evento para que más personas se enteren de éste y conseguir mayor difusión.

Imagen 5. Facebook: publicación 5 de septiembre.

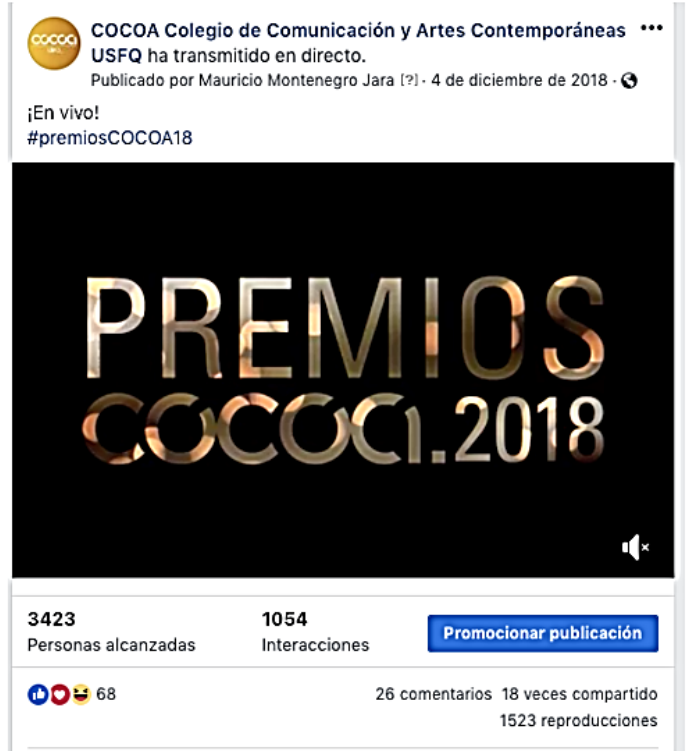

\begin{tabular}{|c|c|c|}
\hline \multicolumn{3}{|c|}{$\begin{array}{l}\text { \#orgulloCOCOA } \\
\text { El proyecto de titulación "Marca Guápulo“ de la USFQ Alumni Domenica } \\
\text { Arias, de la Carrera de Com. Org y Relaciones Públicas - USFQ comenzó } \\
\text { a participar desde mayo de este año en el concurso de presupuestos } \\
\text { participativos para barrios que realiza el municipio de Quito. Este año el } \\
\text { proyecto ganó } \$ 17.000 \text { y fue el único de la parroquia Itchimbia en ganar. } \\
\text { Este presupuesto debe ser aplicado dentro del barrio en virtud de } \\
\text { fortalecer la Marca Guápulo, apoyar a los emprendimientos barriales por } \\
\text { medio del desarrollo de la feria Paseo en Guápulo y dar una solución a las } \\
\text { problemáticas sociales del barrio. }\end{array}$} \\
\hline \multicolumn{3}{|c|}{$\begin{array}{l}\text { Este proyecto también se encuentra participando para el concurso del } \\
\text { habitat III, el cual otorga } \$ 200.000 \text { para proyectos urbanísticos en } \\
\text { barrios, y exige que este tenga el sustento de un proyecto social. }\end{array}$} \\
\hline $\begin{array}{l}2715 \\
\text { Personas alcanzadas }\end{array}$ & $\begin{array}{l}960 \\
\text { Interacciones }\end{array}$ & Promocionar publicación \\
\hline 0083 & & ntarios 2 veces compartida \\
\hline De gusta & $\square$ Comentar & $\Rightarrow$ Compartir \\
\hline
\end{tabular}

Dicho evento obtuvo gran acogida, logrando un alcance de más de 3.500 personas y más de 1.200 interacciones. Por otro lado, la página ha conseguido que la mayoría de las publicaciones obtengan un promedio de hasta mil personas de alcance, 20 interacciones y más de 30 likes. Cabe mencionar que, en meses anteriores, el alcance era de 300 personas, de 10 a 15 likes, y de 3 a 10 interacciones. Por lo que se puede 
conseguir una interpretación objetiva de los resultados alcanzados con respecto a la gestión.

\section{Conclusiones}

La revolución digital ha significado importantes cambios para la comunicación interna, ya que la Web 2.0 rompió con el paradigma tradicional de pirámide, en donde el DirCom gestionaba los mensajes y colaboradores eran receptores pasivos de la información. Los medios sociales digitales, como herramienta de comunicación interna, dinamizaron el canal horizontal, democratizando la comunicación, y generando protagonismo a los colaboradores como emisores de mensajes y difusores de comunicación. Sin embargo, es importante considerar el desafío que las redes sociales significan para las organizaciones, pues así un mal manejo de esta comunidad virtual, puede afectar la imagen y reputación de cualquier institución. Por ello, la estrategia se vuelve vital en cualquier proceso de planificación estratégica. Así, toda gestión comunicacional debe responder a un estudio que direccione el plan de acción a seguir. Por ello, la página de Facebook del COCOA desarrolló una serie de tácticas basadas en los resultados de un previo estudio realizado que revelaba el perfil y los intereses de su público interno. El impacto y dinamismo de la comunicación y difusión de mensajes fue alto en comparación con los resultados del año 2017. Durante el año siguiente, en el cual se aplicaron las tácticas expuestas en el presente artículo, el alcance del contenido incrementó de manera significativa, así como su comunidad virtual. En este sentido, se recomienda un estudio continuo que evidencie la eficacia del plan propuesto, así como la creación de un plan de contingencia para aplicarlo en caso de ser necesario. 


\section{Referencias bibliográficas}

Andrade, H. (2005). Comunicación organizacional interna. España:

Netbiblo.

Carretón, C. (2007). Las Relaciones Públicas en la Comunicación Interna de la Banca Española. España: Netbiblio.

Castello Martínez, A. (2013). Estrategias empresariales en la web 2.0. España: Ecu.

COCOA Colegio de Comunicación y Artes Contemporáneas USFQ (2018). Página Oficial. Recuperado de:

https://www.facebook.com/USFQCOCOA/?epa=SEARCH_BOX Cusot, G. (2017). Medios digitales y comunicación interna: caso Colegio de Comunicación y Artes Contemporáneas de la Universidad San Francisco de Quito. ComInt DirCom, (3), pp.34-39.

Durango, A. (2015). Mercadotecnia en los Medios Sociales (2nd ed.). IT Campus Academy.

Losada, J. (2004). Gestión de la comunicación en las organizaciones. Barcelona: Ariel

Luna Rodríguez, R. \& Pezo Paredes, A. (2005). Cultura de la innovación y la gestión tecnológica para el desarrollo de los pueblos. Bogotá: Convenio Andrés Bello.

Salo, N. (2000. La comunicación interna, instrumento fundamental de la función directiva. Red Dircom. Recuperado de http://www.reddircom.org/textos/salo.pdf 



\title{
6
}

\section{Construcción de imagen y reputación digital}

\author{
Vanessa Karina Duque Rengel \\ Universidad Técnica Particular de Loja \\ Ulianova Elizabeth Espinosa Jiménez \\ Universidad Técnica Particular de Loja
}

\begin{abstract}
PARA CITAR: Duque, V. \& Espinosa, U. (2020). Construcción de imagen y reputación digital. En Puertas-Hidalgo, R., Abendaño, M. \& ValdiviezoAbad, C. (Eds.), (2020). Comunicar: de la táctica a la estrategia. Cuadernos Artesanos de Comunicación, nº178 (pp.97-115). La Laguna (Tenerife).
\end{abstract}

\section{Resumen}

En el complejo entorno digital actual, cobra importancia la gestión efectiva del diálogo con los stakeholders, que se centra en los canales digitales, como los portales web y los medios sociales, que se consolidan como herramientas para la creación de vínculos de fidelización con dichos públicos. Estas redes sociales representan una nueva forma de construir una identidad on-line, no solo personal sino también organizacional, al agregar y compartir nuestra actividad en la red. Por otro lado, las plataformas digitales significan una importante oportunidad de negocios e indispensable para conseguir contactos, además que genera una ventaja competitiva, por lo que se encuentra abierta a un número extenso de posibles clientes y adicionalmente dichas plataformas permiten la creación de alianzas estratégicas que van alineadas al interés de la actividad empresarial.

En este capítulo se analiza, cómo dichos medios digitales aportan a la construcción activos intangibles, como: Imagen y Reputación. 
Palabras claves: comunicación digital, imagen, imagen y reputación online, medios sociales.

\section{La construcción de imagen y reputación}

$\mathrm{E}$ N LA SOCIEDAD actual, la gestión de comunicación debe estar basada principalmente en la gestión de activos intangibles, que a decir Pérez y Tangarife (2013:143) "se han convertido en uno de los principales generadores de valor para la empresa, aunque no se vea debidamente reflejado en los estados contables". Se debe tener claro que, estos se obtienen a partir de la definición y gestión efectiva de procesos, sistemas y la cultura corporativa.

Así también, lo corrobora Ritter (2013:93) quien establece que estos son producto o resultado de "las habilidades, los conocimientos, la experiencia, la capacidad innovadora y de gestión para generar ganancias futuras, aspecto disparador del valor de una empresa cuando ésta tiene éxito, aumentando la brecha entre su capitalización (valor) de mercado y su patrimonio neto".

Es entonces, que la gestión de invisible assets o activos intangibles fundamenta su valía en los beneficios que ofrecen a las empresas, pues no basta con ofrecer buenos servicios o productos, sino en establecer valor agregado a su accionar a través de la gestión de reputación, imagen, sentido de pertenencia, etc., que les permite ser más competitivas en el mercado.

Estos activos se basan en generar "vínculos empresariales con los stakeholders (grupos de interés) - mismos que - se dan de múltiples maneras; la más evidente se presenta a partir de la forma en que la empresa es percibida, a través de la publicidad, por sus diversos grupos de interés, como resultado del esfuerzo estratégico en materia de 
imagen de marca y reputación por parte de la organización" (Orozco y Roca, 2011:274).

\subsection{Definiendo la imagen}

La imagen corporativa puede definirse como una "evocación o representación mental que conforma cada individuo, formada por un cúmulo de atributos referentes a la compañía; cada uno de esos atributos pueden variar, y puede coincidir o no con la combinación de atributos ideal de dicho individuo" (Sánchez y Pintado, 2009:19)

El mercado altamente competitivo al que nos enfrentamos, exige la gestión y generación de una imagen corporativa positiva, que pueda brindar confianza y credibilidad a los públicos. De ahí su importancia, como punto de partida del relacionamiento con los stakeholders. Sin duda, generar una buena imagen siempre será un buen comienzo, sin embargo, debemos recordar que esta es temporal, por tanto, para conservarla en el tiempo, la empresa deberá volcar todos sus esfuerzos en fortalecer los vínculos con sus diversos grupos de interés.

Esta tarea no es nada fácil, pero puede iniciarse estableciendo una coherencia entre lo que dice y hace la empresa, que debe evidenciarse en la comunicación offline y online. Si nos centramos en la online, nos enfrentaremos a nuevos retos productos de la sociedad de la información y el conocimiento en la cual nos encontramos, caracterizada por públicos nativos digitales (tendencia en crecimiento) cada vez más exigentes, hiperconectados y multifacéticos.

Por ello, el construir una buena imagen a través de nuestros canales de comunicación digital (portal web, redes sociales, intranet, etc.) es indispensable en el contexto actual, pues esta deberá reflejar y transmitir la filosofía organizacional, a fin de generar confiabilidad en nuestro público de interés, que requiere, entre múltiples necesidades: 
información completa, clara y precisa e interacción constante e inmediata.

\subsection{Definiendo la reputación}

La reputación es un "sentimiento positivo hacia una persona o institución que integra tres vectores: admiración, buena estima y confianza. Está en la base de la confianza y se trata de un sentimiento de enorme relevancia puesto que es el detonante de las actitudes y comportamientos favorables hacia una empresa, una institución o un país" (Carrera, Alloza y Carreras, 2013:1).

Bajo esto contexto, Ritter (2013) explica que la credibilidad y la confianza son los atributos claves para la construcción de la Reputación Corporativa.

La reputación corporativa está llamada a convertirse en una "referencia obligada para los gestores de los intangibles empresariales y para todos aquellos que quieran adentrarse en el conocimiento y la gestión práctica de uno de los recursos estratégicos más importante para cualquier organización que aspire ser excelente y competitiva" (Carrera, Alloza y Carreras, 2013:1).

Tal ha sido la importancia que ha generado la reputación en el mundo empresarial, que desde hace varias décadas se premia a las empresas más reputadas, así:

La revista Fortune de los Estados Unidos reconoció el valor de una buena reputación corporativa cuando en 1982 decidió por primera vez publicar su ya legendario ranking sobre las empresas más admiradas.

Hoy en día, la edición que publica esa investigación es el número más vendido en el año y el listado de empresas que figuran en él continúa 
siendo el patrón de medida más popular de imagen corporativa en todo el mundo. (Ritter, 2013:8)

\subsection{Relación entre imagen y reputación}

Partamos explicando que "la imagen y la reputación corporativa constituyen activos intangibles, fuentes de numerosas ventajas competitivas que no pueden dejarse al azar y que deben ser cuidadosamente gestionados" (Schlesinger, 2009:9).

En el semantograma de valores intangibles propuesto por Costa (2015) se establece que la imagen es la consecuencia de la identidad de la organización y esta dará como resultado la generación de marca y procesos de innovación, que desembocarán posteriormente en credibilidad, notoriedad y sostenibilidad. Tal como se evidencia en la figura 1.

Figura 1. Aspectos fundamentales de la gestión estratégica y comunicacional del DirCom

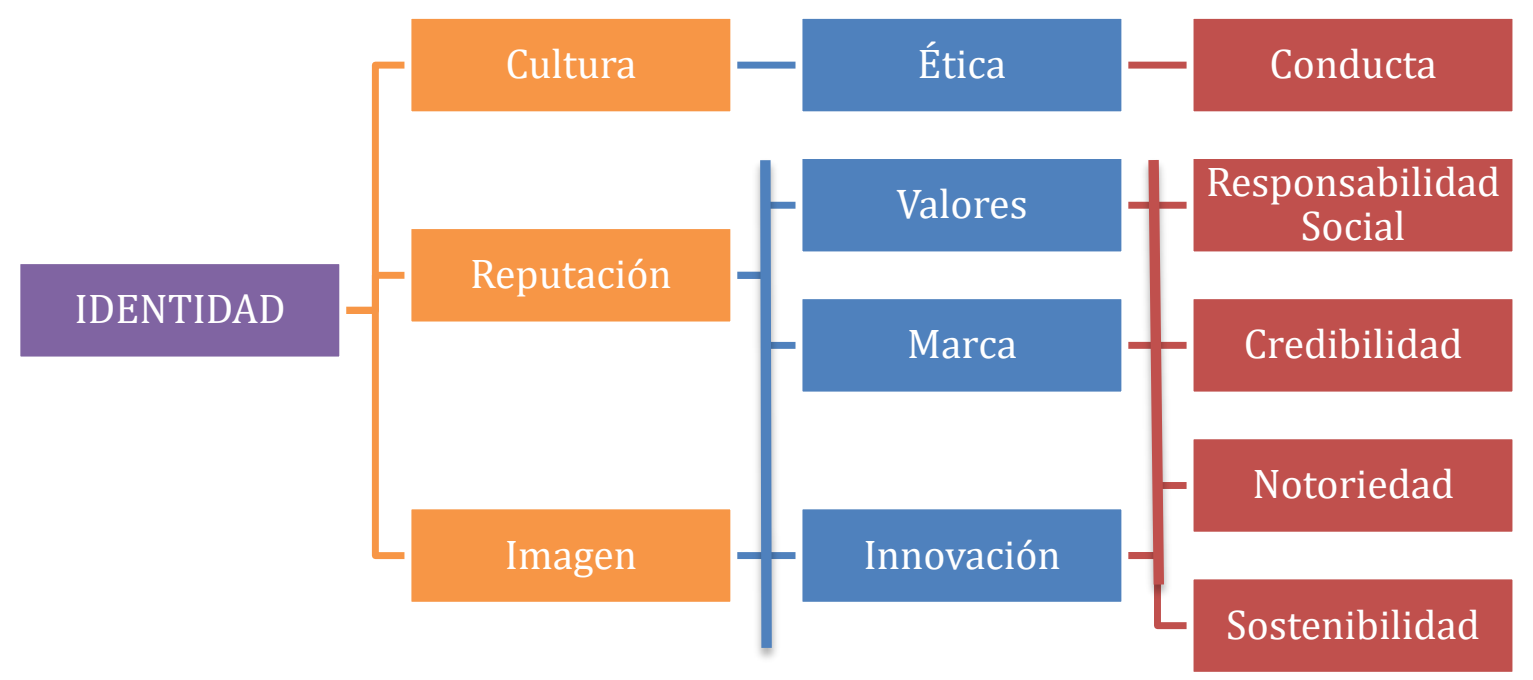

Fuente: Costa (2015). Elaboración propia

Por otro lado, la reputación al igual que la imagen es resultados de la identidad y coincide con la generación de marca y se adiciona valores, de la primera desemboca la notoriedad y de la segunda la 
responsabilidad social y de las dos la credibilidad. Como hemos observado hasta ahora la imagen y reputación están íntimamente ligadas, y aportan a la generación de otros activos intangibles de gran importancia para la organización.

Hoy, estos activos intangibles recobran mayor relevancia, pues las empresas están más expuestas que nunca al ojo público a través de la gran red de redes, el Internet.

Figura 2. Principales diferencias entre Imagen y Reputación
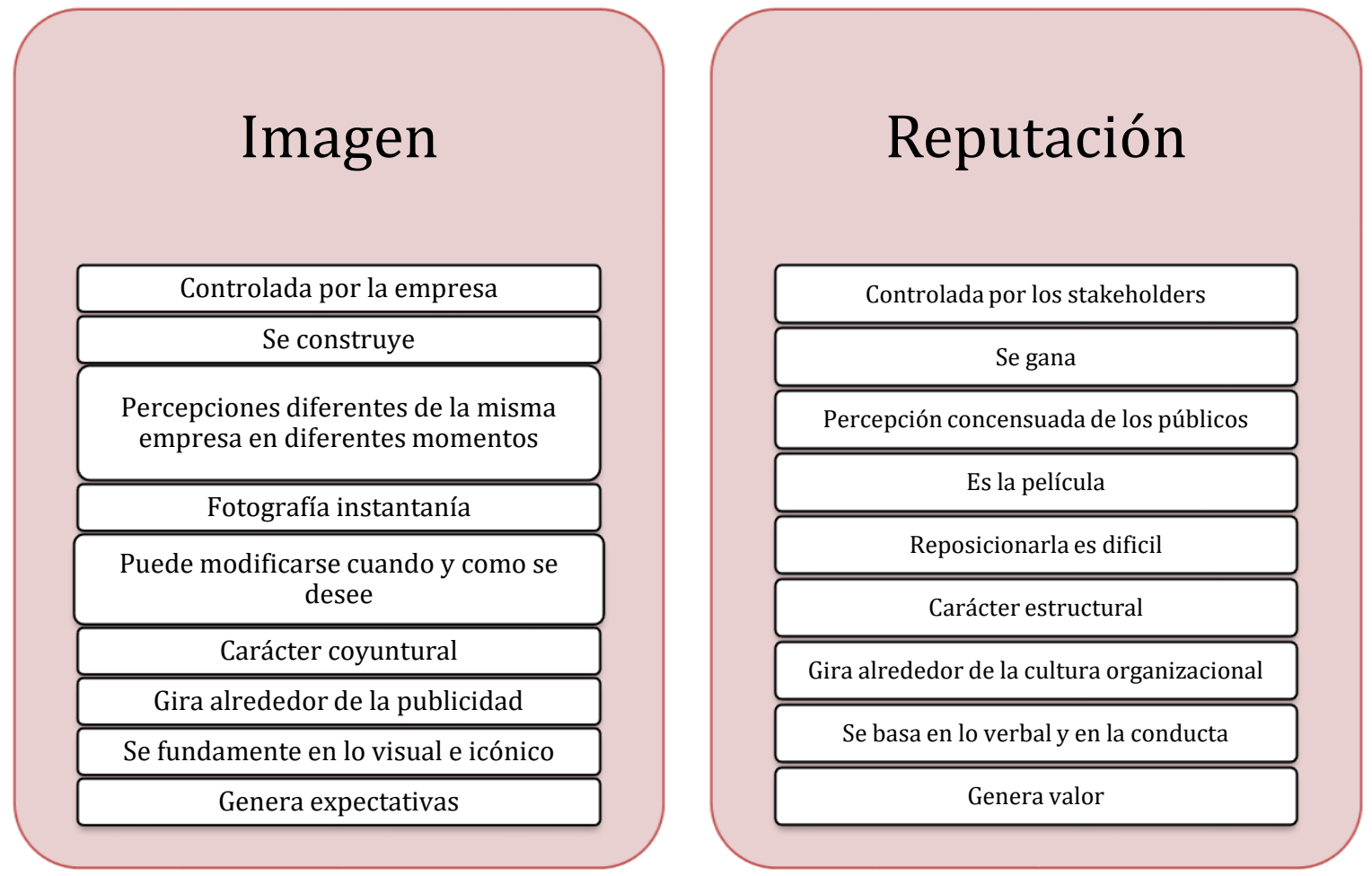

Fuente: Ritter (2013:137). Elaboración propia

Desde otra mirada, Michael Ritter, nos muestra las diferencias de la imagen y reputación, estableciendo de manera general que la imagen es momentánea, es decir de corto plazo y que la reputación constituye la construcción a largo plazo. Sin embargo, las dos son frágiles frente al público, si no son gestionadas adecuadamente. 


\subsection{Acciones que benefician a la imagen y reputación empresarial}

Para alcanzar esa tan anhelada imagen y reputación positiva, es necesario trabajar sincronizadamente en todos los estamentos de la empresa, para generar:

1. Servicios y productos de calidad.

2. Adecuada atención al cliente.

3. Proyección de una buena imagen y reputación de $\mathrm{CEO}$, como líder empresarial.

4. Un gobierno corporativo transparente y ético.

5. Y, sobre todo, coherencia entre lo que decimos, pensamos y hacemos.

Y estos elementos deben reflejarse en todos nuestros canales, más aún en los digitales, que son la ventana a nuestros públicos de interés, que están presentes en la web por largas horas del día.

\section{La gestión de comunicación empresarial y las Tics}

Si bien el mercado ha experimentado drásticos cambios como resultado del nacimiento de la Sociedad de la Información y el Conocimiento, en pleno siglo XXI, estos han desembocado en la modificación de los modelos de negocio que hoy más que nunca necesitan innovar y presentar al público de interés, cada vez más heterogéneo, una propuesta de valor que satisfaga las necesidades personales de cada grupo de stakeholders.

Frente a ello, quienes gestionan la comunicación en las empresas han optado por potenciar más prácticas y acciones online, que offline, pues, en la actualidad nuestros públicos son digitales y exigen la presencia de la organización en la web. 


\subsection{Medios sociales y canales de comunicación digital}

El auge de los medios sociales y canales de comunicación digital en el siglo XXI ha incrementado con el pasar de los años, debido a la necesidad del hombre por informar y mantenerse comunicado de manera rápida, clara, específica y veraz.

En la actualidad los nuevos medios sociales han obligado a las empresas a tener mayor proactividad y capacidad de relación online y offline, obteniendo credibilidad en sus productos y servicios. Cuya identidad de la empresa debe de ir a la par de lo que dicen y hacen porque de esto depende la percepción que tendrán sus stakeholders.

A decir de López (2013:111) los medios sociales "generan nuevos códigos de comunicación, interacción, colaboración y cooperación entre sus participantes; son de gran aceptación sobre todo en niños, adolescentes y adultos jóvenes".

Ahora bien, toda actividad realizada en los canales de comunicación debe de ser cuantificada, capaz de medir si las acciones comunicacionales llegaron al público objetivo de manera eficaz, eficiente, generando retroalimentación, impacto y posicionamiento de la marca en la mente del consumidor, o por el contrario es necesario rectificar los errores para futuros proyectos comunicacionales.

\subsubsection{Inventario de medios y canales de comunicación digital}

La comunicación corporativa de las empresas día tras día se va adaptando a los nuevos canales de comunicación digitales, con el fin de lograr retroalimentación, posicionamiento en la mente del cliente, generar credibilidad y reputación de la marca. Sin embargo, no es primordial que las marcas estén presentes en todas las redes sociales, por el contrario que en las pocas que estén, vayan ligadas a los objetivos 
de comunicación empresariales y tengan contenido de interés para el usuario.

Sin embargo, para Townsend (como se cita en Espinosa y Duque, 2018) El internet o la red de redes, como también se le ha llamado, es un medio que ofrece una gran diversidad de recursos digitales para un sinfín de usos y que poseen características diferentes. Éstos se clasifican en tres grupos.

Tabla 1. Clasificación acerca de los tipos de internet

\section{Autor}

Townsend

\section{Definición}

Transmisivos: Son los que apoyan el envío, de manera efectiva, de mensajes del emisor a los destinatarios. Activos: Permiten que el aprendiente actúe sobre el objeto de estudio, y, a partir de esta experiencia y reflexión, construya sus conocimientos.

Interactivos: Su objetivo es que el aprendizaje se dé a partir de un diálogo constructivo, sincrónico o asincrónico, entre individuos que usan medios digitales para comunicar e interactuar.

Fuente: Townsend (2000:2) Elaboración propia

De esta manera, las empresas se ven beneficiadas del internet porque les brinda gran cantidad de recursos digitales, que les permitirá escoger la más adecuada, teniendo en cuenta a qué se dedican, público al que se dirigen y que imagen e identidad desean proyectar y alcanzar.

NEXT_U (s/f) detalla en la figura 3, los 5 canales de marketing digital que permiten desarrollar e implementar estrategias comunicacionales planteadas por las organizaciones. 
El éxito o fracaso de las empresas en la red de redes, se debe al uso adecuado de los medios sociales y canales de comunicación, porque estos permiten la multimedialidad, usabilidad, interactividad y la frecuencia de actualización de la información del sitio web. La gestión de estas plataformas puede beneficiar o perjudicar en la imagen y reputación de la empresa, pues evidencia la importancia que se le da gestión de los públicos digitales (que crecen exponencialmente).

Figura 3. 5 canales de Marketing digital

Las redes sociales son uno de los principales teniendo en cuenta que diariamente muchas personas se unen a estas plataformas.

Asimismo, según un estudio de IAB Spain, $81 \%$ de los usuarios de Facebook lo utiliza para seguir a marcas.

Los blogs y las páginas web son claves en cualquier estrategia de marketing digital y se han convertido en canales que se complementan entre los blogs traerán más tráfico a tu web, pero para lograrlo es importante que el contenido y el formato de tu blog sea de calidad, de esta manera se cumplirá su objetivo final que es atraer lectores y clientes.
El email marketing es muy utilizado gracias a su contenido dinámico y atrayente como imágenes, videos, gifs, entre otros recursos, los cuales logran captar la atención de los clientes.

SEO, el cual busca mejorar el posicionamiento de estos en los diferentes buscadores a través de un conjunto de tácticas, lo cual permitirá aumentar la visibilidad de tu sitio web y obtener un mayor número de visitas.

El SEM es uno de los canales de marketing digital que está tomando cada vez más fuerza. Este se trata de las campañas publicitarias a través de pagos, que de dan mayor visibilidad a tu marca.

Fuente: (NEXT_U., s/f:1). Elaboración propia.

\subsubsection{La página web como una mirada al contexto empresarial}

En la actualidad las páginas web empresariales abren múltiples vías de comunicación para el usuario, como información de contacto, chat, creación de comunidades virtuales, buscar trabajo y enlaces a las redes 
sociales o blogs. Logrando con ello que el nivel de alcance sea mayor y se genere un engagement con el público objetivo y potencial.

Es importante subrayar las características que debe poseer una página web empresarial, según Universia de España. (2012), que destaca lo siguiente:

\section{Figura 4. ¿Qué tiene que tener una página web empresarial?}

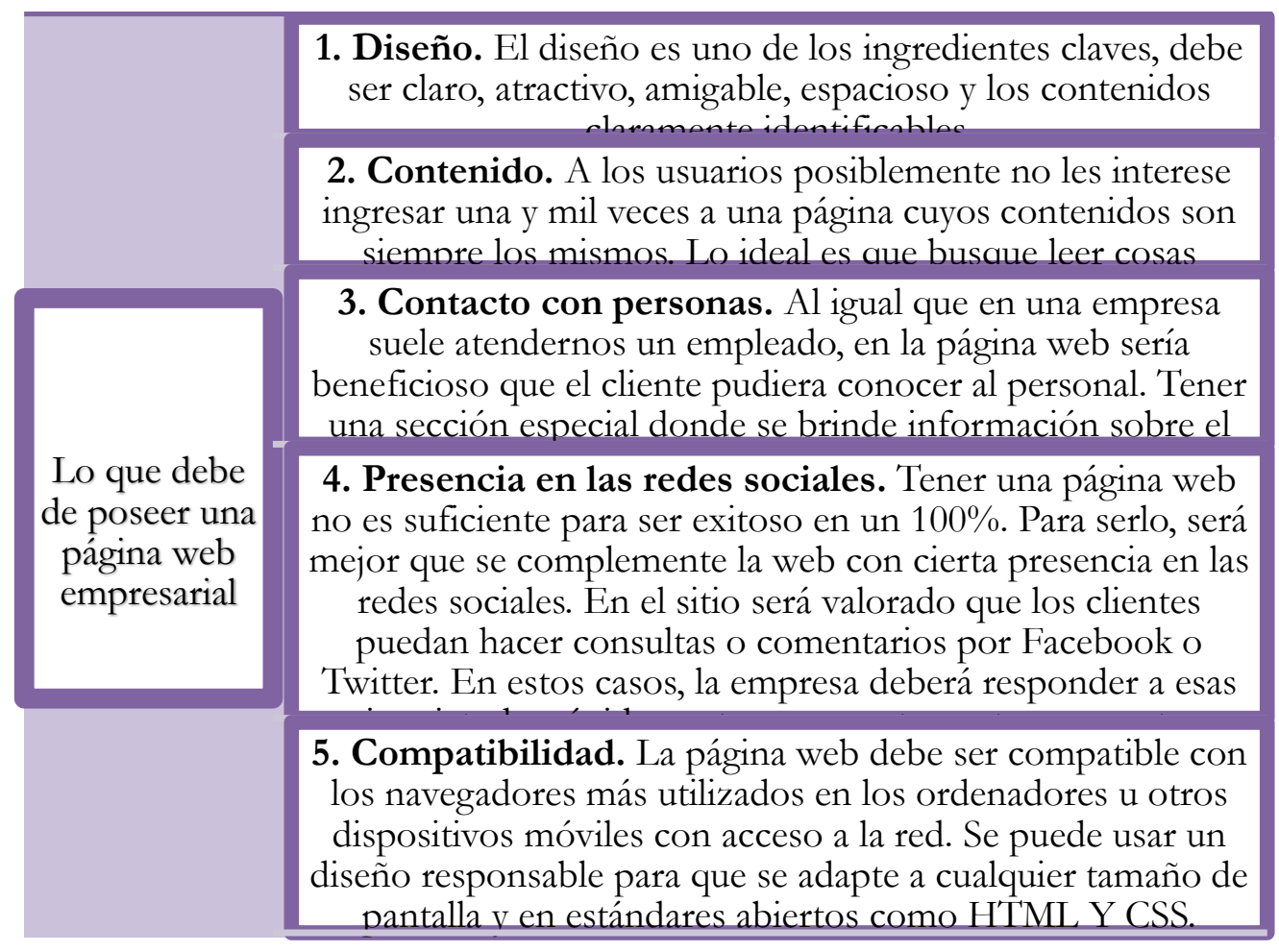

Fuente: Universia (2012). Elaboración propia

Para que una página web sea exitosa, llamativa y amigable con el usuario, se debe de tomar en cuenta el tipo de organización los servicios que ofrece para de esta manera elegir el diseño acorde. Ahora bien, si tomamos en cuenta las sugerencias citadas anteriormente (Universia de España, 2012) probablemente ganaremos más usuarios que visiten nuestra página y que posiblemente se conviertan en nuestros clientes y compren nuestros productos. 


\section{El papel de los medios sociales en el diálogo con los públicos}

La participación de los usuarios en los medios sociales se encuentra estrechamente ligada a la relación que estos establecen con la marca, permitiendo con ello la participación activa de los públicos para hacerse escuchar, ya sea mediante un reclamo, comentario, compartiendo contenido e incluso creándolo.

Por tal motivo, es primordial que las empresas cuiden de su comportamiento en la web, sobre todo, procurar ese diálogo directo y constante con sus stakeholders, de manera que se puedan fortalecer la relación con estos.

En América Latina las redes sociales con mayor aceptación entre los millenials, de acuerdo al estudio de Telefónica 2016 son: Facebook, Instagram, YouTube y Twitter. Basados en estos resultados nuestros esfuerzos deben centrarse en la gestión efectiva de estos medios para generar en un primer momento notoriedad, imagen, reputación y finalmente el posicionamiento digital.

\subsection{Facebook}

Es una red social que fue creada en el año 2004 por Mark Zuckerberg, que permite crear perfiles (fanpage) atractivos y útiles para que las empresas puedan llegar a su público objetivo de manera eficaz y eficiente. Esta red social sigue creciendo y tiene más de 70 millones de usuarios en todo el mundo.

Para Dans (como se cita en Espinosa y Duque, 2018:84) "la página en Facebook requiere atención: si la empresa la crea, pero no la atiende, estará dando una mala imagen. La misma mala imagen que puede dar atenderla sin criterio, sin sentido común, con agresividad o con actitudes inadecuadas". 
Según el estudio de Espinosa y Duque (2018:129) acerca del posicionamiento de la red social Facebook en las agencias corporativas de Colombia, se menciona que:

En la actualidad, cada vez son más las agencias - empresas en general - que les interesa tener presencia en redes sociales para comunicar su imagen corporativa, captar nuevos mercados y persuadir en el cliente a que realice la compra de un servicio. Sin embargo, se debe de tomar en cuenta que al momento que se decide crear una cuenta empresarial en redes sociales, esta debe ser alimentada estratégicamente, publicando contenidos de interés y valor para el usuario, caso contrario no aportarán a los objetivos empresariales.

\subsection{Twitter}

Es una red social personal, profesional y empresarial en la cual se puede expresar pensamientos, noticias, informaciones, interactuar con amigos o seguidores y escribir nuestras quejas públicas sobre algún producto o servicio todo esto en un inicio en 140 caracteres, sin embargo, en 2017 se incrementan a 280.

Se sugiere que para su gestión es primordial que las empresas tengan una cuenta por cada país, porque los objetivos empresariales son diferentes, al igual que el público al que se dirigen y las estrategias de comunicación empleadas.

Para Espinosa y Duque (2018:103) "el engagement es importante para las empresas, porque da a conocer la empatía del cliente (público objetivo) con la marca. En los cuales, ellos terminan siendo los principales embajadores, vendedores comerciales, prescriptores y referentes de la misma". 


\subsection{Instagram}

Es una red social que le permite al usuario subir imágenes, videos, compartir información, tomar fotos, grabar videos, seguir a más personas, transmitir en vivo, crear historias durante 24 horas y seleccionar una serie de filtros para ser las publicaciones llamativas visualmente.

Para generar una buena reputación empresarial, las agencias deben destacar ante las demás con publicaciones de fotografías, videos, estados, en vivo, logrando con ello que la audiencia se conecte, interactúe, se sienta parte de la empresa y esté pendiente de las publicaciones. Así como lo menciona Parera (s/f) en la siguiente figura.

Figura 5. 10 maneras sencillas de mejorar el engagement en Instagram y lograr que tu audiencia te adore

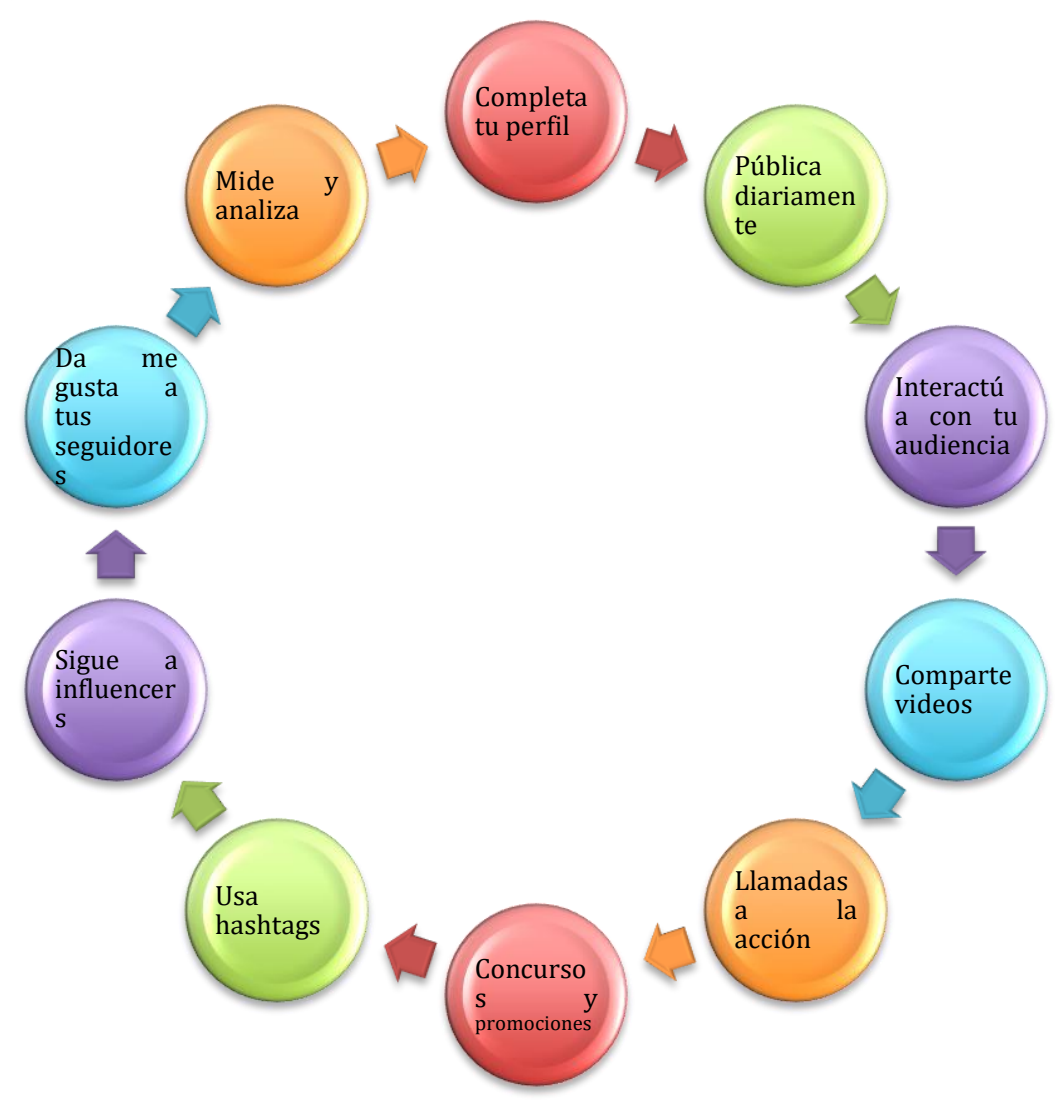

Fuente: (Parera, s/f). Elaboración propia 


\subsection{You'Tube}

"Fue creado por tres antiguos empleados de PayPal en febrero del 2005 (...) es un reproductor en línea basado en Adobe Flash para servir su contenido” (Roldán, como se cita en Espinosa y Duque, 2018:29).

El poseer un canal de YouTube de la empresa es de suma importancia porque ayuda a llevar el tráfico hacia el sitio web, abrir un espacio para interacción, la participación y la comunicación a nivel global.

\section{Figura 6. Pasos de como YouTube te ayuda en la estrategia de comunicación online}

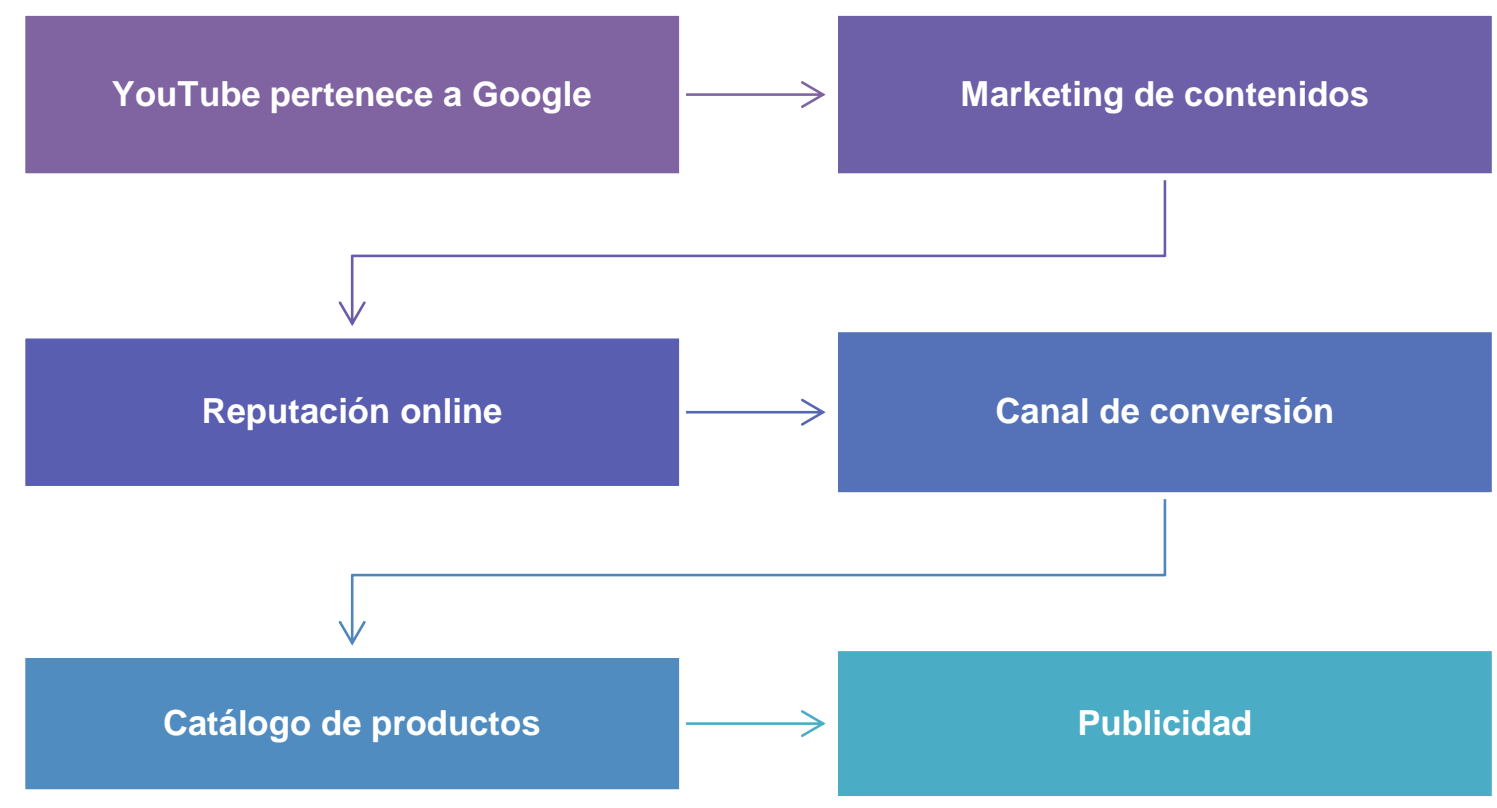

Fuente: Estudios de Comunicación (como se cita en Espinosa y Duque 2018:30). Elaboración propia

YouTube es un medio de gran impacto y alcance, hay cifras que revelan que se publican más de trece horas de videos por minuto que se reproducen en todo el mundo de forma instantánea y en el año 2008 YouTube abarcó el 75\% del espacio de sitios para ver videos online en los Estados Unidos. De hecho, hubo ocasiones en las YouTube tuvo más espectadores que la misma televisión norteamericana reproduciendo un programa de televisión en vivo (De Cicco, 2008:31). 


\section{Nuevas potencialidades de los medios digitales}

En la actualidad, los medios digitales son la plataforma donde los usuarios pasan gran parte de su tiempo, por lo cual es importante compartir con el público contenido de valor de la empresa, que será de utilidad para potenciar la reputación de la marca.

Es entorno a este nuevo escenario que toma prioridad las tendencias de gestión de comunicación digital, que se constituyen, como ya lo habíamos dicho, en la base de la creación de la imagen y reputación empresarial.

Se debe puntualizar que no basta con tener una pág. web y presencia en redes social (que siguen siendo importantes como canales de comunicación digital), es necesario ir más allá y gestionar la reputación online que se forja a partir de los contenidos (tipos, calidad, innovación, etc.) disponibles en la red, y más aún la retroalimentación que de sus públicos se genera, pues estos ejercen gran influencia en los públicos de interés, que buscan recomendaciones basados en la imagen y percepción de otros consumidores.

Por ello, es recomendable crear equipos de trabajo destinados netamente a la gestión del marketing y comunicación digital, inclusive hoy se habla ya de DirCom Digital, personal capacitado para la gestión de contenidos y con experiencia para que pueda hacer frente ante una posible crisis de reputación.

Además, el uso de los medios digitales les permite abrir las puertas al mundo, teniendo la posibilidad de atraer personas de otros lugares y fidelizar usuarios todos los días durante todo el año. 


\section{Imagen y reputación a través de los portales web y redes sociales}

En este apartado final, nos resta destacar que la construcción de la imagen y reputación de las organizaciones es un trabajo diario, a través de las experiencias que provocamos en nuestros públicos mediante el contenido e interacción personalizada que establecemos, pues hoy más que nunca se requiere escuchar a los stakeholders, como seres únicos e irrepetibles.

Bajo este antecedente Espinosa y Duque (2018:130) señala que:

Es importante crear y posicionar la imagen corporativa de la empresa en sitios web y redes sociales con la finalidad de ganar credibilidad, confianza de los clientes, decisión de compra de un producto y la fidelización por parte de los stakeholders porque en momentos de crisis son ellos quienes la respaldan. Es importante además que los contenidos que vayan a ser publicados estén relacionados con la marca para no perder el profesionalismo y credibilidad de la empresa.

Para alcanzar esa credibilidad debemos mostrarnos transparentes y sobre todo debe existir una coherencia evidente entre lo que decimos y lo que hacemos. La gestión de estos medios debe estar incorporada en la gestión de la estrategia global de la empresa.

Finalmente, los medios digitales poseen ventajas y desventajas en el manejo de la comunicación de la empresa, está en su criterio si hacer inversión y uso de las mismas u optar por lo convencional.

\section{Referencias bibliográficas}

Carrera, E., Alloza, A. y Carrera, (2013). Reputación Corporativa. Madrid: LID Editorial 
Espinosa, U. y Duque, V. (2018). Análisis de los sitios web y las redes sociales como plataformas de comunicación corporativa de las agencias de comunicación en Sudamérica- Caso de estudio Colombia, periodo 2017 (tesis de pregrado). Universidad Técnica Particular de Loja, Loja, Ecuador.

Gutiérrez, A. (2016). Millennials en Latinoamérica, una perspectiva desde Ecuador. Ecuador: Telefónica.

López, M. (2013). Aprendizaje, competencias y TIC: Aprendizaje basado en competencias. Primera edición. México: Pearson Educación, S.A de CV.

Orozco, J. y Roca, D. (2011). Construcción de imagen de marca y reputación a través de campañas publicitarias de RSC. Sphera Pública, (11), 273-289.

Pérez, G. y Tangarife, P. (2013). Los activos intangibles y el capital intelectual: una aproximación a los retos de su contabilización. Saber, Ciencia y Libertad. 8(1), 143-166.

Sánchez, J. y Pintado, T. (2009). Imagen Corporativa influencia en la gestión empresarial. Madrid: ESIC Editorial.

Schlesinger, M. (2009). Imagen y reputación corporativa. Estudio empírico de operadoras de telefonía en España. Teoría y Praxis. (6), 9-29.

Ritter, M. (2013). El valor del capital reputacional. Porque la opinión que tiene el público de su empresa es un activo estratégico. Olivos: Ritter \& Partners.

\subsection{Otros documentos}

Costa, J. (2015). Módulo Identidad, Imagen y Marca Corporativa. Ecuador: UDLA y Máster Internacional DirCom

Estudios de Comunicación. (2017).

NEXT_U. (s/f). 5 canales de Marketing digital. Recuperado el 03 de abril del 2019 de https://www.nextu.com/blog/canalesmarketing-digital/

Parera, E. (s/f). 10 maneras sencillas de generar engagement en Instagram y lograr que tu audiencia te adore ( $Y$ todo ello sin tener que invertir ni un centavo!). Recuperado el 02 de abril de 2019 de https://postcron.com/es/blog/como-mejorar-el-engagementen-instagram/ 
Universia. (2012) ¿Qué tiene que tener una página web empresarial?

Recuperado el 03 de abril de 2019 de http:/ / noticias.universia.es/empleo/noticia/2012/10/22/9758 39/que-tiene-tener-pagina-web-empresarial.html 



\title{
Inbound marketing: de la confianza a la venta
}

\section{Comunicar con precisión y agregar valor en la información}

\author{
Nancy Estella Vesga \\ Universidad Autónoma de Bucaramanga
}

PARA CITAR: Vesga, N. E. (2020). Inbound marketing: de la confianza a la venta. En Puertas-Hidalgo, R., Abendaño, M. \& Valdiviezo-Abad, C. (Eds.), (2020). Comunicar: de la táctica a la estrategia. Cuadernos Artesanos de Comunicación, nº178 (pp.117-134). La Laguna (Tenerife).

\section{Resumen}

Los modos de consumo han cambiado. La forma como una organización, una institución o una empresa se acerca a sus clientes es diferente desde los años noventa. Los procesos comunicativos para el acercamiento a un consumidor potencial se han convertido en una oportunidad de aproximación, verdadero conocimiento y fidelización, más que en la agresiva y potencialmente peligrosa venta pura y directa; hoy es una forma de fortalecer lazos a largo a plazo, al fin y al cabo, las definiciones más cercanas al mercadeo son precisamente las que buscan una verdadera relación con las personas que consumen productos y servicios. El inbound marketing ha captado el sentido de la información, ha potenciado la confianza con datos importantes y relevantes para los clientes y ha logrado hacer que la comunicación sea proactiva tanto para la empresa como para el consumidor.

Palabras claves: confianza, inbound marketing, asertividad, Kotler; Kaplun, legitimidad 


\section{Introducción}

T A PREMISA de Phillip Kotler en su definición del mercadeo que 1 aduce: "el marketing es un proceso social y administrativo mediante el cual grupos e individuos obtienen lo que necesitan y desean a través de generar, ofrecer e intercambiar productos de valor con sus semejantes" (Kotler, 2001:7) ha sido entendida; por fin su valiosa definición comprendida en los años noventa como la simple mercantilización de productos, ha tomado la dimensión de intercambio de valor que merece.

Teniendo en cuenta lo anterior y reforzando la definición desde el punto de vista de "la ciencia y el arte de explorar, crear y entregar valor para satisfacer las necesidades de un mercado objetivo, y obtener así una utilidad" (Kotler, 2005:7), que hace conexión con las nuevas relaciones de sentido entre el cliente y sus aspiraciones, sus deseos y sus necesidades.

Sin embargo, el presente artículo no se centra en hablar de mercadeo o marketing, se centra en comprender la relación de una metodología mercadológica de cara al mejoramiento de las relaciones de largo plazo entre la organización y sus stakeholders, tomando como base la comunicación precisa que agrega valor e información de calidad, convirtiéndose en proceso de pedagogía y confianza para potenciar las ventas de la empresa. Aquí el mercadeo responsable toma un giro interesante de pertinencia y calidad, en resumidas cuentas, se hablará desde la comunicación eficiente y productiva con los consumidores, clientes o interlocutores válidos en la organización.

Para hablar del tema, se debe abordar con pensamiento crítico el abordaje explicativo de las premisas comunicativas; de manera 
afortunada los modelos de comunicación que organizan las formas en que las personas interactúan, cambió ostensiblemente desde los años cuarenta, aunque se pretenda presentar para el mercadeo aún el sistema lineal, como la posibilidad de pensar la comunicación con el cliente y las formas de alcanzar su compra.

Ya el funcionalismo desde sus aplicaciones pragmáticas de educar, informar y entretener, más informar y entretener que educar, conecta directamente con la estructura del mercadeo tradicional, manteniéndose en dicha situación con las metodologías más conocidas, alejándose de ellas el marketing social, el marketing relacional y el inbound marketing.

Hablar de comunicación en el mercadeo es abordar, en primera instancia los conceptos de comunicación que se alejen de la linealidad matemática y se acerquen a las estructuras del mundo de la vida que tienen que ver con la valoración del sentido y las pretensiones de validez, más que con las artimañas, engañosas que el marketing tradicional trata de imponer, quitándole la posibilidad a la organización de generar relaciones de largo plazo con las personas.

\section{Un inicio con premisas de conceptualización comunicativa}

Lo primero que es necesario aclarar es la conceptualización avanzada de la comunicación (Gómez, 1997:5):

Se puede definir comunicación como las relaciones de sentido a partir de un determinado lenguaje. Es la puesta en común de nuestras construcciones del mundo, de nuestras perspectivas de vida. La comunicación es un intercambio de los modos con que contamos para vivir. Comunicándonos tratamos recíprocamente de entender esos modos de resolver la supervivencia y lo que pensamos de ella ${ }^{1}$. No es

${ }^{1}$ Gómez, S. (1997) Et al. Enseñanza de Lenguaje y competencia comunicativa. 
la comunicación un proceso de transmisión de mensajes, pero sí es el encuentro de las expresiones simbólicas de los seres humanos en circunstancias de tiempo y espacio específicos. Más allá de esto exige la correlación de consensos y expresiones divergentes que hacen nutrir el sentido y el lenguaje.

$\mathrm{Si}$ se quieren establecer relaciones de sentido con los demás, es necesario comprender que la comunicación resuelve el proceso de supervivencia, las construcciones del mundo, recrean las posibilidades de resignificar colaborativamente lo que se 'es' en el mundo y lo que personifica la instancia del ser humano desde sí mismo. Todo lo anterior con la potenciación simbólica de las circunstancias en las que el proceso comunicativo se da.

Es necesario comprender el presente concepto desde el punto de vista argumentativo de la Teoría de la Acción Comunicativa, que potencia la calidad de la comunicación desde el consenso, la divergencia y la construcción de la confianza valorativa.

"Las comunicaciones constituyen el nexo más importante en las organizaciones, pues de su buen o mal funcionamiento dependerá la acción de la organización y los resultados esperados en tal acción. A partir de esta idea, dos conceptos sociológicos sobresalen en las posibles formas de responder las cuestiones vinculadas con la comunicación: entendimiento comunicativo sistémico y la acción comunicativa. Aunque ambos contienen ideas procedentes del funcionalismo sistémico, sin embargo, es necesario establecer algunas diferencias básicas. Las raíces epistemológicas del entendimiento comunicativo sistémico, provienen de la comprensión de 'hechos sociales' de Durkheim, mientras que en la acción comunicativa hay que

En: Modulo 1. Formación permanente en la enseñanza de la lengua materna. Bucaramanga: 1997. Ministerio de Educación MEN, Universidad Industrial de Santander. Material modificado y resumido para utilización académica universitaria en Comunicación Social (p.3). 
buscarlas en Max Weber. Habitualmente, son puestas como teorías excluyentes una de la otra, como se manifiesta en los citados debates en torno a los conceptos de actor y acción entre seguidores de Habermas y Luhmann (Habermas, 1987 como se cita en Pond Vidal, 2015:309).

$\mathrm{Al}$ argumentar que es necesario entender la acción comunicativa desde el desarrollo de una inteligencia cultural, basada en la estructuración consciente de la misma que conduce a la "interacción en la que los sujetos capaces de lenguaje y acción entablan una relación interpersonal con medios verbales y no verbales. El concepto central es la interpretación referida a la negociación de situaciones susceptibles de consenso (los significados se establecen con argumentos), para ello el lenguaje se hace fundamental como medio de entendimiento y diálogo igualitario" (Habermas, 1987); necesariamente se desarrolla un concepto de confianza a partir de la pretensión de validez que carga en sí misma la valoración razonada de los comportamientos a partir de los propios conocimientos, creencias, actitudes, mediadas por las normas y las intencionalidades de la conducta. La confianza y licitud se instituye con el establecimiento de la acción razonada desprovista de la importancia de evitar el engaño, en este proceso comunicativo el mercadeo y sus variantes tiene un trabajo arduo que hacer para su propia legitimación de sentido y significación simbólica.

Para complementar el concepto de comunicación, se valora la relación de la misma con la pedagogía, que dentro de los componentes modernos y acertados de los modelos de comunicación aparece el que potencia al emisor como un perceptor en doble vía (ver Jean Cloutieu, propuesta emisor-receptor/receptor-emisor y Mario Kaplun -emirec) teniendo en cuenta las prealimentaciones de los individuos, la clara intencionalidad de comunicación y la capacidad de convertirse en perceptor de emisión a quién se le consideraría destinatario de la emisión. Teniendo en cuenta que este modelo es más intersubjetivo, 
apunta a teorías modernas que tratan directamente con los estudios culturales y apalanca la educación constructivista como la forma factible de comunicación con sentido y significación simbólica.

La relación sumatoria de comunicación y las percepciones modernas de su concepto, aunado a la educación y su posibilidad de construcción compartida de conocimiento pertinente, teniendo en cuenta además que el tema a abordar es generación de valor a partir de la información suministrada, finalmente se convierte en un elemento valioso de pedagogía en el marketing, se acerca a la reflexión metodológica existente que pone en práctica la adquisición y administración de datos valiosos de los presentes y potenciales clientes.

\section{Hacia la búsqueda de la confianza y el conocimiento}

Las organizaciones en busca de su permanente relación proactiva con los clientes, acuden a metodologías interesantes de conexión con quienes hacen parte de sus públicos de interés. En este momento se debe decir que no es solo con los actuales, factibles y potenciales usuarios, sino todo el espectro de relaciones actuales y sobre todo posibles que en el futuro se puedan dar y permanecer.

Lo que antes se pretendía establecer como fidelización y comunicación directa bajo tácticas de mercadeo que han pasado desde el ATL por encima de la publicidad y por el BTL más arriesgadas y por decirlo más creativas que van por debajo de la línea de publicidad, hoy son el referente primario de la comunicación con los clientes, específicamente desde algoritmos de contenido, elaborados y pensados al público específico y con valores agregados que interesan, enseñan y conectan con relaciones de sentido y realmente de largo plazo.

Este modelo de marketing, el cual ayuda a representar y darle organización lógica a los productos y servicios para encontrar un 
resultado de los clientes actuales y potenciales, puede ser comprendido desde el mismo significado de modelo; según Phillip Kotler se divide en cuatro partes importantes para su desarrollo y aplicación en la investigación, estas son:

- Marketing masivo: estos se producen de forma masiva por lo que su promoción también es intensiva, su costo de producción es relativamente bajo y no tiene gran diferenciación (Soto, 2012).

- Marketing focalizado: está basado en la selección de un segmento o foco de posibles clientes adecuado a las características de su producto o servicio, a través de un análisis íntegro del entorno y las posibilidades de la empresa (Ebuala, 2015).

- Marketing del cliente: se preocupa por satisfacer las necesidades del cliente con el producto y el conjunto de actividades relacionadas con su creación, entrega y consumo (Espinoza, 2015).

- Marketing online: es la aplicación de las estrategias de comercialización llevadas a cabo en los medios digitales. Las técnicas off-line son imitadas y traducidas a un nuevo mundo, el ámbito digital, que aparecen herramientas como la inmediatez, las redes que surgen día a día, y la posibilidad de mediciones reales de cada una de las estrategias empleadas (MD Marketing Digital, 2013).

\section{El inbound marketing o marketing de la atracción asertiva}

Se dice que el 80\% de las personas prefieren obtener información de la empresa a través de artículos que de contenido publicitario (Sordo, 2016). Este es un precedente importante y fundamental para comprender la dimensión comunicativa e interacción proactiva con los potenciales clientes o usuarios de los productos y servicios que las organizaciones, empresas o instituciones ofrecen.

El concepto de Inbound marketing se ubica en el marketing online. Se habla que su aparición data entre los años 2005-2006 y por primera vez 
aparece como concepto y metodología en el libro Inbound Marketing: Get Found Using Google, Social Media, and Blogs (Halligan, B, Shah D, Meerman S, David, 2009). Cuyo reconocimiento al aumento de conceptos pertinentes y su persuasión hacia los clientes trascendía al marketing de contenidos2, que se convertiría en pieza clave para desarrollar la técnica de atracción, se habla entonces de la evolución del pull marketing o técnicas no intrusivas para atraer usuarios interesados en productos o servicios de una marca.

Consiste en una serie de técnicas de marketing dirigidas a incrementar el número de visitantes que registra una determinada página web, un blog o un perfil en redes sociales, con el fin que acaben convirtiéndose en seguidores, es decir, registros con los datos de aquellas personas que se han interesado por los contenidos online de la empresa. (Ebuala, 2015)

Esta definición suele visibilizar solo una pequeña parte del impacto que puede tener, encontrar una forma de conexión con los clientes si se les ofrece información de relevancia e interés particular. Si bien es cierto que lo que se busca es en cierta medida atraer "seguidores" a partir de su tráfico en diferentes medios virtuales, también es de relevancia comprender que no cualquier información es útil y no cualquier comunicación es valiosa. Tener en cuenta el sentido particular del cliente, aleja a la organización del peligro de masificar nuevamente la información y caer de nuevo en el error del modelo del marketing masivo.

\footnotetext{
${ }^{2}$ Los consumidores buscan contenidos relevantes y de buena calidad. Por lo que se debe tener una estrategia de publicaciones que satisfagan las necesidades informativas del público al que deseamos atraer.

Rubio, I. (2016). Inbound Marketing: definición, pilares y acciones principales. Marketing. Recuperado de https://www.marketinet.com/blog/inboundmarketing-definicion-pilares-acciones-principales\#gref
} 
Por ello una definición que se acerca y sin embargo es reduccionista sería: "es la estrategia de generar contenido relevante, de alto valor con el propósito de generar interés de los futuros clientes" (Halligan \& Shah, 2010:15).

El inbound marketing "se basa en la atracción, donde el consumidor llega al producto o servicio en Internet específicamente en redes sociales, páginas web o blogs de las empresas atraído por un mensaje o contenido de calidad y obviamente de su interés". (Del Santo, 2012)

El término de atracción, bastante sospechoso y sin embargo útil en este contexto, trata exactamente de lo que busca el modelo en cuestión, pues atraer a alguien como seguidor, funciona en la medida en que la forma como se está cautivando su interés, tiene que ver directamente con su personalidad, su estilo de vida, su formas de concebir el mundo de la vida y por lo tanto el sentido simbólico que le da a la información, produciendo de antemano una conexión directa y casi indisoluble entre dicho contenido y el individuo. Aquí se presenta una indudable comunicación en doble vía, que puede ser aprovechada y tenida en cuenta por la empresa para potenciar sus ofertas de productos o servicios para los individuos en cuestión.

Al basarse el sistema en la atracción donde el consumidor llega al producto o servicio en internet específicamente a partir de redes sociales, páginas web, correos electrónicos o blogs, es necesario que el mensaje y su contenido de valor sea de alta calidad, pertinencia, credibilidad, interés, pues de esta manera se generará confianza y se desarrollará una relación que potencialmente será fidelización a la marca.

Para poder comprender lo anterior es necesario hacer la inmersión a su 'jerga' que, como temática de mercadeo cae en los anglicismos que se tratarán de manejar en castellano. El primer término relevante es el 
Buyer's Journey. Es el viaje del comprador, es decir, el proceso de convertirse en cliente. Es un proceso de investigación activa en el cual una persona pasa a través de etapas de conducción de compra, estas son conocimiento ${ }^{3}$, consideración ${ }^{4}$ y finalmente la decisión (Hubspot Academy, 2009).

Imagen 1. Desarrollo metodológico de Inbound Marketing

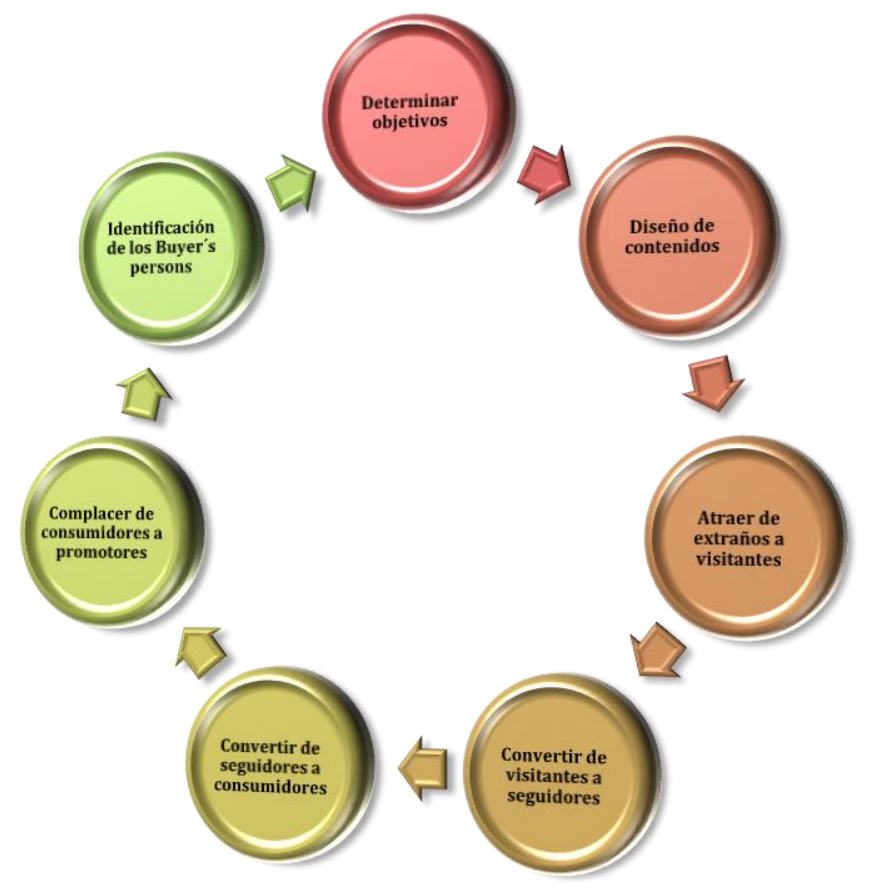

Fuente: Hubspot Academy (s.f). Elaboración propia.

Dentro del desarrollo metodológico del inbound marketing es pertinente comprender que el que adquiere mayor importancia es el de atraer y mantener. En esta etapa se considera conquistar 'extraños' para convertirlos en visitantes regulares de los sitios donde lo relevante es desarollar un contenido que brinde información seria y con sentido de pertinencia para el visitante, con el fin de capturar su atención sin interrupciones, en la dinámica de su cotidianeidad y complacer lo que da su búsqueda y el seguimiento para su primera adquisición.

\footnotetext{
${ }^{3}$ Cuando el prospecto experimenta o expresa síntomas de un problema.
}

${ }^{4} \mathrm{El}$ prospecto entiende y tiene definido cuál es su problema. 
Las Buyer's persons son compradores ideales, cuyo rastreo se realiza basados en datos reales con datos demográficos, patrones de comportamiento y motivación de compra, sin embargo lo realmente trascendental es el genuino interés por patrones de consumo.

Otro aspecto relevante y del que se ha hablado con regularidad en el proceso de creación de la estrategia del inbound marketing es el contenido notable, este debe ser indudablemente atractivo para el visitante, substancial, interesante, útil, con real trascendencia y teniendo en cuenta la relevancia del contexto, utilizando las herramientas básicas de contenido del inbound marketing que son: los blog, los vídeos, las fotografías, los libros digitales (e-book), la presentación de trabajos; con ello se logra establecer la travesía del visitante a partir de la atracción, la conversión (persuación), el cierre y la complacencia del visitante.

Es importante recalcar que el contenido notable no es solo la información que se brinda, son los medios que se convierten en canales de doble vía y conversación permanente con el visitante, tales como las redes sociales ${ }^{5}$, los blogs, páginas web, email, los landing page (páginas de destino), o los call-to-action (llamadas de atención).

El Search Engine Optimization ${ }^{6}$ SEO que busca la optimización de motores de búsqueda, es clave para establecer coherencia con las demás herramientas de uso para la generación de contenido en la estrategia de inbound marketing, seguida del desarrollo del contenido con un propósito y la amplificación del mismo en redes sociales y la obtención de enlaces para el contenido pertinente, el visitante

${ }^{5}$ Las redes sociales son herramientas muy buenas para interactuar con los clientes. Gracias a ellas se sabrá qué puntos fuertes se tienen y cuáles necesitas mejorar, según la opinión de los clientes. Una buena gestión de redes sociales aumentará la reputación online.

${ }^{6}$ El Search Engine Optimization o posicionamiento en buscadores atrae tráfico de alta calidad a nuestra web o nuestro e-commerce es fundamental. Para ello tenemos que trabajar en estrategias de SEO y SEM para mejorar nuestro posicionamiento a la hora de aparecer en las búsquedas del consumidor. 
convertido en promotor, replicará también información importante que pueda seguir realimentado el conocimiento construido en doble vía.

De igual manera, juegan un papel fundamental las páginas de destino (landing page) donde sus prácticas sobresalientes van desde entablar una relación de amabilidad y buena accesibilidad, pasando por una construcción clara de confianza, precisión, cuidar una imagen prolija y sencilla y siempre lo simple y limpio es mejor que lo saturado y barroco.

Al convertir un consumidor en promotor, uno de los recursos más utilizados y sin duda de alto impacto es el correo electrónico. 3.2 billones de personas en el mundo utilizan diariamente correo electrónico y el 94\% lo redireccionan, esta es una oportunidad clara de generar el sentido de promoción a partir de la complacencia de información a partir del envío de información dirigida y particularizada al visitante que se convirtió en promotor.

Imagen 2. Inbound marketing

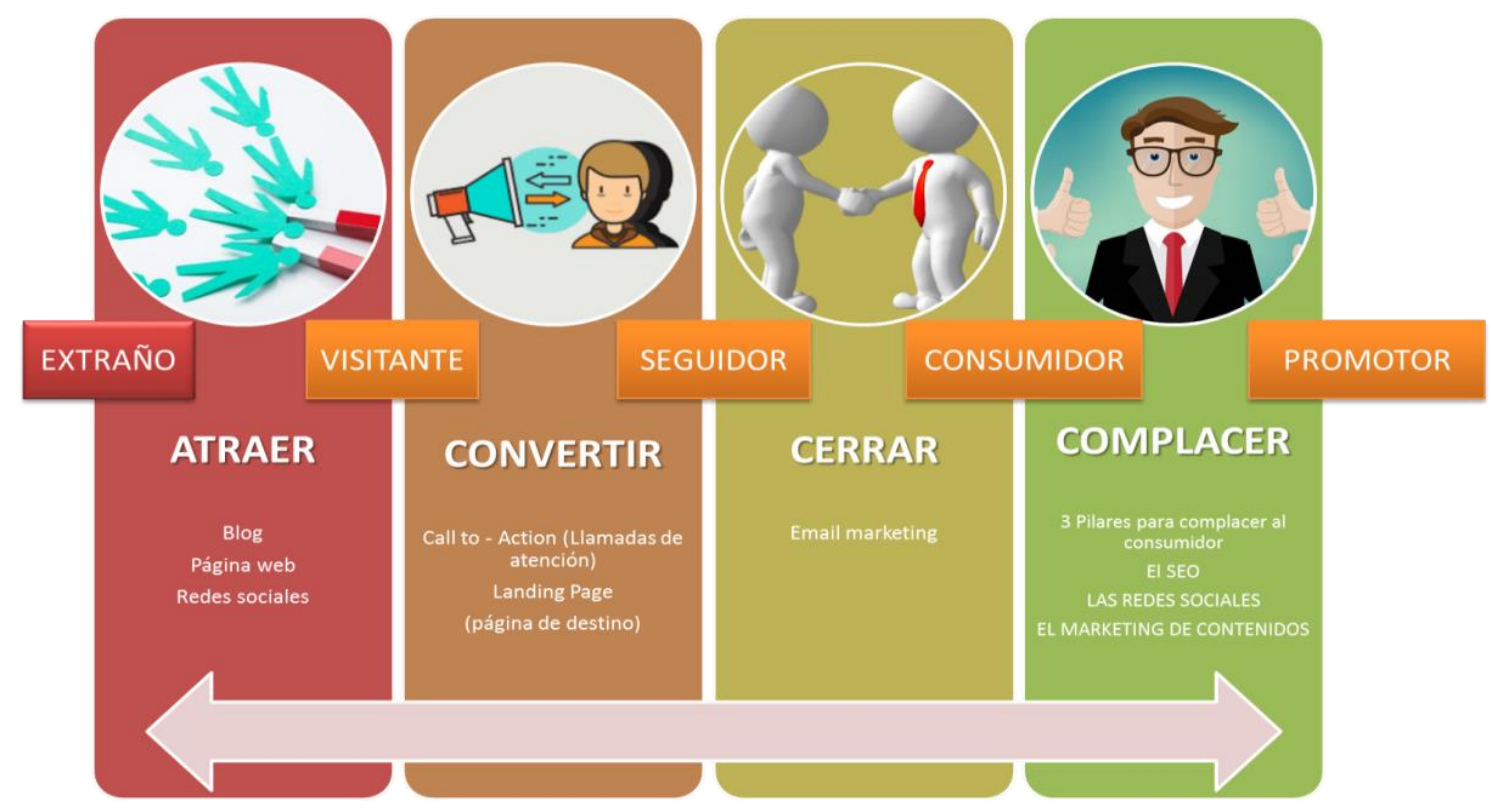

Fuente: Hubspot Academy (s.f). Elaboración propia 
Si se desea una definición más técnica del proceso "este último engloba un conjunto de técnicas de atracción de tráfico web y automatización del marketing — tales como la optimización para los motores de búsqueda en Internet (Search Engine Optimization o SEO) o el pago por clic_- entre las que se cuenta el marketing de contenidos" (Equipo InboundCycle, 2014).

Entender que el marketing de contenidos hace parte del inbound marketing conecta directamente con la intención de ir más allá de la elemental automatización en su sentido amplio de la palabra, es conectar con el interlocutor y tenerlo en cuenta como válido. El marketing aquí trasciende y busca además de datos, conexiones de sentido y valor que generen realimentación constante y valiosa con sus clientes.

Además de las ventajas de una conexión directa con los seguidores, "el inbound marketing permite segmentar a los usuarios en función de las acciones que realizan mientras navegan — como consultar la página de precios de un site o descargar un cierto número de e-books-, generando así una información que agilizará la labor del departamento comercial" (Valdés, 2014).

Al organizar datos también se establece una relación de inclinaciones particulares de los seguidores que tienen intereses personalizados en ambientes específicos. El seguidor no navega por navegar, aunque la tendencia de procrastinación ${ }^{7}$ es cada vez más frecuente, tienen claro el sentido de su navegación.

El marketing de contenidos es una táctica más del marketing de la atracción o inbound marketing, busca brindarle al seguidor sentido y valor agregado en sus búsquedas, mientras adquiere información valiosa que

\footnotetext{
7 Significa posponer o aplazar tareas, deberes y responsabilidades por otras actividades que nos resultan más gratificantes pero que son irrelevantes. Procrastinar es una forma de evadir, usando otras actividades como refugio para no enfrentar una responsabilidad, una acción o una decisión que debemos tomar.
} 
puede ser usada para poner su producto en su propia dimensión de navegación. Una forma certera de entender que va más allá y comprender que es comunicación en doble sentido es comprender que el marketing de contenidos como su nombre lo indica produce solo estructuras de información y la atracción tiene que ver con el tráfico, las veces de ingreso, el posteo de alguna temática, la información brindada, el número de veces de ingreso y sobre todo que se haya convertido en Buyer's person.

Por lo tanto, mientras que el marketing de contenidos tiene como único objetivo atraer y fidelizar tráfico online, la finalidad del Inbound Marketing va mucho más allá. El propósito no se limita a incrementar el número de visitantes de un site, sino que también emplea diferentes estrategias para que este tráfico web se convierta en una base de datos y lograr que las personas interesadas en la empresa conozcan los beneficios de sus productos y servicios y lleguen a adquirirlos o contratarlos. En definitiva, se trata de educar a los usuarios sobre las bondades de una marca y acompañarlas hasta el momento de la compra (e incluso, después, con el objetivo de que esta acción tenga continuidad). (Valdés, 2014)

Es importante comprender que los contenidos otorgados a grado de comunicación en doble vía deben tener tanto sentido para el seguidor que lo debe hacer regresar las veces que sea necesario. El sentido de venta cambia a significación de contenido con simbología específica para el visitante regular y el promotor habitual.

Por eso, si se plantea crear una estrategia de inbound marketing, es necesario prestar una especial atención el aspecto de valor de la información bidireccional, ya que será una de las claves del éxito del proyecto mercadológico - comunicativo. Si no hay capacidad de crear contenido sólido, de calidad y relevante para el público objetivo, jamás se alcanzarán los propósitos planteados. 


\section{Del extraño al cómplice}

Emulando el famoso libro de Joan-Carles Mèlich (1995:141), donde a partir de la filosofía de la vida cotidiana se hace una inmersión hacia la educación de las personas desde su propio mundo de la vida, la idea del inbound marketing busca precisamente reconocer en el otro la viabilidad de valor en la construcción del conocimiento y a partir de sus potencialidades, generar empatía con la información de relevancia y una relación real con la comprensión del mundo a partir del compartir, legitimar y promover su saber más allá de la compra.

Es preciso saber que la experiencia del consumidor inicia con la creación de interacciones genuinas y legitimadas con los consumidores, en este momento el factor de educación a partir de la información de alta utilidad que ayude a incrementar conocimiento y construcciones simbólicas de mundo. Con respecto a la innovación que implica un cambio de paradigma de pensamiento a partir de la transformación y salir de los moldes establecidos inclusive por las tendencias; y la comunicación personalizada no impersonal o ajena a los intereses del consumidor que lo haga sentir único, importante y relevante en el proceso de encuentros de sentido.

El inbound marketing plantea la forma de optimizar recursos a través del aprovechamiento del conocimiento de los consumidores y la sistematización del público al cual va dirigido, hacer pedagogía con el cliente es dotar de significado asertivo y personalidad a las organizaciones, esto y el branding (marca) pueden ser un factor de alta relevancia y puede potenciar las ventas a muy bajo costo.

Esta dimensión mucho más humana del marketing, más allá de las ventas pone en una nueva perspectiva y abre una relación única con clientes fidelizados con la estrategia de la organización y muy probablemente sincronizados con sus propios intereses, estilo de vida 
y formas de resolver su supervivencia, alinea el sentido del valor y genera una garantizada relación de largo plazo con los interesados, más allá de las ventas, legitima el valor del conocimiento compartido, potencia la marca a partir de la información de valor y hace que el cliente no se sienta simplemente usado y lo convierte en un consumidor activo, responsable y con el conocimiento suficiente para decidir de manera comprometida, solidaria y legitimada.

En este punto los promotores se convierten en los cómplices de un proceso de comunicación que resuelve no solamente la búsqueda de conocimiento continua del ser humano, sino además se renuevan los deseos y completan el ciclo para iniciar nuevamente el intercambio de saberes, significación y sentido, legitimado y claramente retribuible, donde la confianza en doble vía se hace visible, y potencia la comunicación y la resolución activa de procesos de intercambios de valor.

\section{Referencias bibliográficas}

Del Santo, O. \& Álvarez, D. (2012). Marketing de atracción 2.0. México: CC Editoriales.

Ebuala. (2014). Marketing de Focalización. Ebuala. Recuperado de http://ebuala.es/marketing-de-focalizacion

Espinoza, G. (2007). Marketing orientado al cliente. Gestiopolis. Recuperado de http://www.gestiopolis.com/marketingorientado-al-cliente/

Gómez, S. (1997). Enseñanza de Lenguaje y competencia comunicativa. En: Modulo 1. Formación permanente en la enseñanza de la lengua materna. Bucaramanga: Ministerio de Educación MEN, Universidad Industrial de Santander. Material modificado y resumido para utilización académica universitaria en Comunicación Social.

Habermas, J. (1987). Teoría de la acción comunicativa. Vol. I. Racionalidad de la acción y racionalización social. Madrid: Taurus 
Halligan \& Shah. (2010). Inbound Marketing: Get Found Using Google, Social Media and Blogs. Estados Unidos: John Wiley and Sons, Inc.

Inboundcycle. (2016). Cómo el Inbound marketing puede contribuir con el branding de tu empresa. Inbound Cycle. Recuperado de https://www.inboundcycle.com/blog-de-inboundmarketing/branding-e-inbound-marketing

Inboundcycle. (2016). Las principales herramientas del Inbound Marketing. Inbound Cycle. Recuperado de https://www.inboundcycle.com/blog-de-inboundmarketing/las-principales-herramientas-de-inbound-marketingebook

Inboundcycle (2017). El papel de los contenidos en el funnel del Inbound Marketing. Estrategias y Herramientas. Blog de Inbound Marketing. Recuperado de https://www.inboundcycle.com/blog-deinbound-marketing/papel-contenidos-inbound-marketing-guia

Kaplun, M. (1998). Pedagogo de la educomunicación popular. Recuperado de

http://educomunicacion.es/figuraspedagogia/0_mario_kaplun. htm

Kotler, P. (2001). Dirección de Mercadotecnia. México: Prentice Hall Hispanoamericana.

Kotler, P. (2005). Las preguntas más frecuentes sobre marketing. Bogotá: Norma.

LeadsRocket. (2016). Guia de introducción. Inbound Marketing. Recuperado de http://www.leadsrocket.com/hsfs/hub/158961/ file-19661595pdf/docs/inbound_marketing.pdf

Mèlich, J. C. (1995). Del extraño al cómplice. Barcelona: Anthropos. Md Marketing Digital. (2013). ¿Qué es el marketing digital? MD Marketing Digital. Recuperado de http://www.mdmarketingdigital.com/que-es-el-marketingdigital.php

Pont, V. J. (2015). La comunicación de Jürgen Habermas y el construccionismo sistémico de Niklas Lubmann: posibilidades de un paradigma de sintesis. Recuperado de file:///C:/Users/unab/Downloads/DialnetLaComunicacionDeJurgenHabermasYElConstruccionismoS5283626.pdf 
Rubio, I. (2016). Inbound Marketing: definición, pilares y acciones principales.

Recuperado Sitio Web:

https:/ / www.marketinet.com/blog/inbound-marketingdefinicion-pilares-acciones-principales\#gref

Sordo, A. I. (27 de octubre de 2016). 10 tipos de contenido que tu audiencia prefiere [actualizado 22 de febrero de 2018]. Blog Hubspot. Recuperado de https://blog.hubspot.es/marketing/tiposmarketing-contenidos

Soto, B. (2012). Qué es el marketing masivo. Recuperado sitio web: https://www.gestion.org/que-es-el-marketing-masivo/

Thlink marketing (2017). Guia Hubspot de Inbound marketing para empresas de TI. Descargables Inbound Marketing. Recuperado de https://www.thlink.marketing/hubfs/Descargables_inbound_ Marketing/guia_hubspot_inbound.pdf https://www.thlink.marketing/hubfs/Descargables_inbound_ Marketing/guia_hubspot_inbound.pdf

Valdés, P. (2014). Inbound Marketing: ¿Qué es? Origen, metodología y filosofía. Inbound Cycle. Recuperado de http://www.inboundcycle.com/inbound-marketing-que-es

Valdés, P. Quer, A. \& Hernández, B. (2014). Los contenidos. El pilar de cualquier estrategia de Inbound Marketing. Inbound Cycle.

Recuperado de https://www.academia.edu/24760507/los_contenidos_el_pilar _de_cualquier_estrategia_de_inbound_marketing 


\title{
Confianza y reputación en tiempos de infoxicación
}

\author{
Stefani del Cisne Paladines Carranza \\ Universidad Técnica Particular de Loja \\ Jenny Jovita Yaguache Quichimbo \\ Universidad Técnica Particular de Loja
}

\begin{abstract}
PARA CITAR: Paladines, S. \& Yaguache, J. (2020). Confianza y reputación en tiempos de infoxicación. En Puertas-Hidalgo, R., Abendaño, M. \& Valdiviezo-Abad, C. (Eds.), (2020). Comunicar: de la táctica a la estrategia. Cuadernos Artesanos de Comunicación, n 178 (pp.135-149). La Laguna (Tenerife).
\end{abstract}

\section{Resumen}

La confianza y la reputación son las palabras clave en toda planificación de la comunicación estratégica y son también los intangibles más vulnerables en tiempos de infoxicación. La sobreexposición informativa, la hiper-transparencia, y una audiencia cada vez más polarizada y altamente participativa, son los desafíos de los gestores de comunicación. Hoy en día las empresas dejan de competir por posicionamiento, ventas y mercado; ha llegado la hora, de que la mayoría enfoque sus esfuerzos en lograr credibilidad, confianza y el respaldo de sus públicos. Las fake news, los ciberataques, resultan igual de desafiantes, por lo que es urgente la creación de políticas y planes de seguridad en concordancia con la estrategia del negocio y la de comunicación. El papel del Dircom radica en medir, analizar y tomar decisiones enfocadas en acciones que generen sentimiento de cercanía con los públicos, logrando una comunicación honesta y ética. 
Palabras claves: infoxicación, confianza, reputación, comunicación, redes sociales, fake news.

\section{Los intangibles de una organización}

$\mathrm{L}$

OS ACTIVOS intangibles son aquellos que no se pueden ver; sin embargo, son parte fundamental de una empresa, se consideran como los cimientos de una construcción, pues de esto depende que una organización cumpla con su misión y visión y que sus acciones sean encaminadas a la realización de sus objetivos. Son la base de toda organización y poseen una riqueza que pocos han explotado.

\subsection{Confianza}

En la sociedad del conocimiento los cambios a partir de la globalización han sido muy significativos, especialmente en la tecnología, provocando en la mayoría de los casos una grave crisis de transparencia afectando así a los intangibles de la organización; esto se ha convertido en el principal desafío para los Dircom en las empresas a la hora de gestionar la confianza con sus diferentes stakeholders.

En el mundo digital, no solo las personas sino todas las empresas públicas y privadas son vulnerables ante situaciones que promuevan la desconfianza, se ha hablado tanto sobre ella que actualmente se emplean diferentes estrategias para contrarrestarla; sin embargo, no siempre funcionan, pues se han dado casos en los que los Dircom desempeñan correctamente su papel; no obstante, la información proveniente de la parte externa de la entidad, pone en riesgo este intangible, generando rumores, noticias falsas, comentarios positivos y negativos ante cualquier publicación digital por parte de la empresa. La problemática radica en la manera en cómo se gestionan los contenidos en la Web, especialmente en las redes sociales, pues hoy en 
día existe todo tipo de información que circula en la "nube" y que no siempre es verdadera, poniendo en duda la transparencia de una organización. Quienes observan este tipo de contenido no siempre se percatan de la veracidad o de las fuentes que emiten estos comunicados, los usuarios comparten al instante la noticia sin indagar más allá de lo que leen, dando como resultado una alimentación constante a la llamada infoxicación.

A pesar de la relevancia que tiene la confianza en las organizaciones en tiempos digitales, existe una falta de estudios centrados en este tema, tomando en consideración que de ella depende que sus públicos tengan el engagement con las diferentes empresas, es decir, que se sientan identificados y no solo eso, sino que la apoyen y le sean fiel en tiempos de crisis; dicho esto, el papel que juega la confianza en relación al mundo web, es preocupante, aunque no todos lo perciban.

La imagen, la confianza, la reputación y la cultura organizacional en sí de una empresa son el blanco perfecto para quienes desean opacarla, conocidos en el mundo digital como trolls, especialmente en redes sociales; es por ello que los encargados de gestionar la comunicación en las diferentes entidades deben estar alertas todo el tiempo, se señala también que no toda la información que se filtra en diferentes medios es verdadera, por lo que hay que actuar ágilmente ante estas situaciones.

\subsection{Gestión de la confianza}

La gestión de la confianza no es otra cosa que la construcción de un vínculo, no solo con el público interno de la organización, sino también con los externos, que permitan establecer una relación estable y duradera, a través de diferentes acciones o procesos que ayuden a consolidar esta analogía. 
La ética profesional es fundamental para la gestión de la confianza, pues la sociedad en general, estará predispuesta a confiar en una institución que muestra transparencia en todos los procesos que emprenda, independientemente de la línea argumentaria, misión, visión, valores, etc., así lo señala también Vinarás (2013:4):

"La comunicación tiene el poder de influir en los individuos y la capacidad de generar y mantener la confianza, así como de perderla, cuando hay incongruencias entre lo se dice y hace, o cuando los mensajes se perciben como promesas inalcanzables o con tintes manipuladores. La relación entre comunicación y confianza dependerá de la eficiencia de la primera en el diseño de sus estrategias y mensajes".

Es importante identificar las diferentes perspectivas que tiene la audiencia respecto a una empresa, para que los Dircom puedan elaborar sus mensajes y finalmente los distribuyan en los canales que ellos crean conveniente; de esta manera el flujo comunicativo empresacliente será de manera bidireccional, en donde exista retroalimentación por parte de la misma hacia sus stakeholders.

\section{La gestión del Dircom en la confianza y reputación de una organización}

La sociedad de la información busca cada vez más la inmediatez, conectividad, transparencia y confianza, Queipo de Llano (2018:1) señala que "el Dircom en la era digital es un posibilitador y movilizador, que aúna estrategia y táctica y que es capaz de entender e interpretar las demandas del mercado y del cliente, el escenario de juego donde opera la compañía y la cultura corporativa, transformando esa escucha activa en oportunidades de negocio a través de una estrategia de comunicación transversal". 
La construcción de los intangibles de una empresa, en este caso, la confianza y la reputación tienen un alto grado de inseguridad especialmente en los medios digitales.

La reputación también es una imagen mental. Y esta se forma a través de una serie discontinua de percepciones y experiencias que se acumulan en el tiempo. Existe en este fenómeno, un factor de contradicción intrínseca: a) la discontinuidad en el espacio-tiempo en la percepción de los signos identitarios de la empresa, y b) el trabajo asociativo de la mente construyendo la imagen. (Costa, 2016:1)

Finalmente, la manera en cómo el Dircom gestiona la confianza y reputación depende del contexto de la organización, de los valores institucionales, misión, visión, etc.; debido a que el profesional cuenta con un perfil que le permite planificar, dirigir y coordinar las diferentes actividades relacionadas a la comunicación empresarial de manera que admita enviar la información pertinente a sus diferentes stakebolders, con la habilidad de generar interacción entre los usuarios y la marca, con la única finalidad de construir y fortalecer la confianza y la reputación.

\section{La sobresaturación informativa: infoxicación}

Actualmente, el acceso a la enorme cantidad de información que existe en el internet es uno de los más grandes beneficios que nos brinda la Web; sin embargo, también se ha convertido en un problema, el término infoxicación, que etimológicamente procede de la composición de las palabras información e intoxicación, lo acuñó Alfons Cornella por primera vez en 1996, (Infonomia, 2012) según el autor, la sobrecarga informativa es difícil de "procesar" o entender causando el síndrome de infoxicación que se caracteriza por la ansiedad y angustia. En resumen, es la incapacidad de análisis al sinfín de información que se sube a la red de redes. 
La infoxicación, de acuerdo con Visentin \& Torvalds (como se citó en Villaroel, 2015:3), es el exceso de información que hace imposible "digerir" a los cibernautas en la red, lo cual ocasiona un déficit atencional ante estímulos infocomunicacionales o la imposibilidad de captar los mismos y reconfiguración del entramada de conexiones cerebrales acorde a los niveles de información actuales.

Ramos (2017:1), la afirma como la enfermedad del siglo XXI de la sociedad de la información, así es considerada la infoxicación; sin embargo, esta apareció junto con el Internet en 1969, es decir, justo con la revolución tecnológica, transformando por completo las diferentes maneras de comunicarse, pasando de lo tradicional a lo digital, así como el continuo bombardeo de información, no sólo por los medios de comunicación, sino por los mismos internautas.

El contenido que circula en la web puede que sea noticioso y hasta mediático; sin embargo, un buen contenido informativo contiene fuentes confiables y una investigación previa, antes de publicarse en cualquier medio.

"Esta saturación informativa que observamos en los medios de comunicación hace que también hoy se discuta el concepto de veracidad de la información que va en consonancia con el grado de redundancia informativa y cómo los medios se complementan en relación a determinados asuntos”. (Pagán, 2007:75)

La saturación informativa fue acuñado por Alvin Toffler llamando la atención de la comunidad científica desde la década de los setenta, explicando el estado psicológico que sufriría la sociedad al estar enfrentada a demasiados cambios en un corto periodo de tiempo, el cual obtendría como resultado que las personas se sobrepasen y se agobien en un escenario postindustrial definiéndolo como "information 
overload" (sobrecarga informativa) refiriéndose a la sobreestimulación sensorial que tendría gran impacto en la capacidad para pensar. (Toffler, como se citó en Romero \& Mancinas, 2016:114-115).

Resulta interesante la manera en que se construyen los mensajes desde el ámbito institucional, debido a que el Internet nos da un sinfín de posibilidades tecnológicas a través de aplicaciones para poder emitir los comunicados; sin embargo, es importante mantener una planificación previa, de manera que los contenidos sean de calidad, no solo para llamar la atención mediática que resulta volátil ante la inmediatez de las redes sociales, es por ello que el diseño de la información es de vital importancia pues de esta depende alimentar o no a la infoxicación.

Los encargados de la elaboración de los mensajes de una institución son los Dircom, Rivera (2013:1), considera que la infoxicación es la contaminación por exceso de información, además de ser adictiva pues mientras se publican fotografías en Instagram, Twitter, etc., las personas tienen un cierto reconocimiento social, llenando de esta manera la red de contenidos; todos comunican y lo ideal para las organizaciones es contar y aportar con un mensaje distinto, pues la repetición acaba por mantener viva la infoxicación.

\subsection{Causa y efecto de la infoxicación. ¿Cómo afecta a una organización?}

El problema no es tener una gran cantidad de información en la web, sino más bien, la manera en cómo la manejan. El libre acceso ha hecho que los diferentes contenidos se vuelvan vulnerables ante los navegantes de Internet, pues no todo lo que está en la Web es cierto, siendo el principal responsable el ciudadano "prosumidor", que en su mayoría genera un exceso de datos, sin información oficial. 
Un ejemplo de infoxicación fue el caso del terremoteo que sucedió en Ecuador el 16 de abril de 2016, en el que muchos de los medios audiovisuales transmitían noticias que se caracterizaban por su espectacularidad, pero no eran de interés general para la población que en aquel momento demandaba otra serie de información. En este sentido, era más importante que los bomberos explicasen a la gente cómo realizar primeros auxilios o qué hacer en caso de réplicas, que las imágenes impactantes de dolor y tragedia.

El exceso de información en tiempos de crisis dificulta la capacidad de las personas a reaccionar ante tanta información y a comprender lo que realmente está sucediendo.

El psicólogo británico David Lewis, en su informe Dying for Information, elaborado para la agencia Reuters, dijo: "knowledge is power, but information is not" y afirmaba que "la exposición a un exceso de información disminuye la capacidad para resolver problemas y causa síntomas como la pérdida de atención y de memoria, y estados de ansiedad que generan angustia porque hay tanta información que no se puede asimilar, y de esta manera el exceso de información incapacita para tomar decisiones sensatas, y entonces provoca un aumento del estrés" (Beneyto, 2013:1).

En un mundo en donde todos están expuestos a la infoxicación las empresas no son la excepción, pues también son afectadas por esta "nueva enfermedad digital" que, aunque ya ha existido desde hace tiempo atrás, es recién hasta los últimos años que se ha puesto en boga.

Para Cárdenas (2014:10), la alta relevancia que tiene la planeación estratégica para las organizaciones es fundamental, además de darle cierto estatus ante otras instituciones que carecen de esta. Para evitar la saturación de información en las empresas es necesario coordinar y diseñar todos los mensajes clave a los diferentes públicos; sus beneficios son muchos y las oportunidades casi infinitas con la única 
finalidad de evitar peligros en el futuro. En este contexto la información se convierte en una herramienta de supervivencia en este nuevo paradigma, de manera que se administren los recursos de manera oportuna, evaluando y controlando el uso de la tecnología por parte del personal.

Según, Días (2014:8) los medios digitales son los principales responsables de esta enfermedad, pues están ayudando a los usuarios a contactarse exclusivamente con el contenido que les interesa, reforzando sus preferencias y opiniones, y disminuyendo la cantidad de oportunidades para contactar de manera diferente, para experimentar algo inesperado y fuera de su zona de confort, para aprender algo nuevo. Finalmente, este proceso culmina en la saturación de contenido y relaciones, a medida que aprendemos continuamente más sobre lo mismo y el contacto con otros similares a nosotros.

Por otra parte, la saturación informativa afecta no solo a las grandes empresas, sino también a las pequeñas y medianas; sin embargo (Rodríguez, s.f) menciona que estas deben de conocer sus capacidades, consiguiendo un nicho de mercado, especializándose y dándole a su consumidor un valor, por la misma razón de ser pequeñas, tienen ventajas frente a las grandes como el acceso a la información del mercado, con la finalidad de que concentren sus esfuerzos en buscar, entender quién es su público, cuáles son sus gustos, sus aspiraciones, qué ven y qué escuchan.

\subsection{Como sobrevivir a la infoxicación}

El exceso de información no es algo que se va a resolver en los próximos años, al contrario, la información se multiplicará de manera más rápida. Sin embargo, Cornella (2000:3-5) afirma que, se debe acostumbrar a la idea de gestionar la información, correctamente, utilizando métodos y herramientas para desarrollarla; además de 
evaluar la manera en cómo las personas se informan, es decir, cómo buscan el contenido, cuál es el proceso que siguen. Menciona también, los tres filtros de información: "información falta", es la que no interesa en lo absoluto; "información interesante", es aquella que tarde o temprano la buscaremos, es decir, que algún día le puede interesar; finalmente, la "información realmente útil", en esta hay que concentrarse, pues es la que va de acuerdo con las líneas críticas de la persona. La autora destaca el error de las empresas de hoy en día, pues destinan recursos económicos a programas de gestión de conocimiento, pero no, la gestión es personal, es decir, se debe capacitar a los empleados e implantar una cultura de gestionar bien la información, para evitar la infoxicación.

Para sobrevivir a la infoxicación es muy importante conocer las herramientas óptimas de búsqueda en Internet, pues la mayoría de internautas desconoce algunas claves para que la exploración sea concreta y específica de manera que se pueda evitar ser infoxicado en la red; según, (Maglione \& Varlotta,s.f) es importante al momento de ingresar en un buscador seleccionar correctamente una palabra clave en el cuadro de texto, que generalmente se encuentra en la parte superior del motor de búsqueda, con la finalidad de que este realice la operación entre toda la información existente en la red. Cada resultado se adapta a los criterios de búsqueda establecidos, acompañado de otras palabras que permitan realizar una búsqueda más específica.

\section{La dieta de la información}

Hoy en día, no es un problema la falta de información pues hay un exceso de ella. El tema es: la "desconexión". El constante flujo comunicativo en la red se ha convertido casi en un reto para la mayoría de personas, pues se han acostumbrado tanto al bombardeo de información que no cabe en la mente del consumidor la idea de alejarse 
por un momento de esto, considerándose algunos como "cavernícolas" por la falta de Internet.

Si bien es cierto, el mundo digital ofrece beneficios sin igual, las facilidades que nos brindan son muchas; sin embargo, el uso incorrecto de esta, han ocasionado un "smoke informativo" de gran relevancia, pero preocupante para pocos. Serrano (2013:164), hace énfasis en la dieta informativa y como principal sugerencia ante el problema actual, hace un llamado a una sociedad más consciente y crítica en la forma y cantidad en el tiempo que le dedican a estar conectados; y en un segundo lugar, a emplear herramientas, aplicaciones y software que sirvan para gestionar toda la información que se recibe diariamente.

\section{E1 papel del Dircom frente a las fake news}

Las fake news, por otro lado, llegan a incrementar el trabajo del gestor de comunicación. Son una amenaza constante para las organizaciones pues el nivel de incertidumbre entre los usuarios aumenta considerablemente poniendo en riesgo a la reputación corporativa y al resto de intangibles.

Según Débora Gray (2018:1), fundadora y directora de la agencia Canela PR, menciona como se puede combatir las Fake News.

1. Enviar a las medias informaciones precisas, relevantes y actualizadas para que la publiquen.

2. Trazar una línea que separe claramente la información de la publicidad o el marketing.

3. Atribuir todos los datos y declaraciones que incluyen los comunicados que difundimos.

4. Habilitar canales que permitan a los medios contrastar y desmentir las noticias falsas. 
5. Controlar la reputación online de las marcas de nuestros clientes para detectar bulos.

6. Colaborar con los medios para desmentir las noticias falsas e identificar su origen.

La clave. Vincular la estrategia empresarial y la de comunicación. Esto no es nuevo, pero puede ser que el día a día, haya permitido que pensemos que la comunicación es solo acción y los colores. El desafío de los gestores de la comunicación es cada vez más grande. Son los responsables de adaptar el contenido. Es decir, lo que la organización tiene que decir a lo que el usuario quiere escuchar. Para ello es sumamente importante definir una identidad clara con unos valores auténticos, en el marco de la ética y la verdad.

\section{Referencias bibliográficas}

Alloza, A., Cachinero, J., \& Pino, I. (2012). ¿Existe la reputación online? Tres respuestas y más incógnitas. Llorente y Cuenca. Madrid: Sagasta.

Beneyto, R. (23 de 09 de 2013). Documanía. Recuperado de https://documania20.wordpress.com/2013/09/23/queriesgos-ocasiona-a-la-salud-la-infoxicacion/

Cárdenas, N. (2014). Gestión de la información en las. TIA, Tecnología, Investigación y Academia, 2 (1), 10.

Casó, R. (06 de abril de 2016). Ramiro Casó. Recuperado de http:/ / ramirocaso.com/la-dieta-informativa/

Collins, D. I. (s.f). Diccionario inglés Collins. Recuperado de https://www.collinsdictionary.com/es/diccionario/ingles/fake -news

Cornella, A. (2000). Cómo sobrevivir a la infoxicación. Acto de entrega de títulos de los programas de Formación de Posgrado del año académico, (pp.3-5).

Costa, J. (14 de enero de 2016). Reputación corporativa. [en línea] Recuperado de https://www.udla.edu.ec/reddircom/2016/01/14/reputacion-coorporativa/ 
Días, P. (2014). From 'infoxication' to 'infosaturation': a theoretical overviewof the cognitive and social effects of digital immersion. Revista Internacional de Comunicación, 8.

Diccionary, C. (s.f). Cambridge Diccionary. Recuperado de https://dictionary.cambridge.org/es/diccionario/ingles/fakenews

El Telégrafo. (21 de octubre de 2018). En Posorja imperó el uso de la violencia ante la justicia. Recuperado de

https://www.eltelegrafo.com.ec/noticias/judicial/12/linchamie nto-cultura-educacion-posorja-guayaquil

El Clarín (30 de octubre de 2018). Un hombre murió tras ser linchado en Colombia por una cadena falsa de Whats App. Recuperado de https://www.clarin.com/mundo/hombre-murio-linchadocolombia-cadena-falsa-whatsapp_0_2NLJiEsZZ.html

García, M. (2018). Relaciones públicas socialmente irresponsables. El caso de la publicidad engañosa y desleal. Methaodos, Revista de Ciencias Sociales, 119.

González, M. (13 de abril de 2018). Qué ha pasado con Facebook: del caso Cambridge Analytica al resto de polémicas más recientes. Xataka. Recuperado de https://www.xataka.com/legislacion-yderechos/que-ha-pasado-con-facebook-del-caso-cambridgeanalytica-al-resto-de-polemicas-mas-recientes

Gray, D. (06 de febrero de 2018). Las fake news, un problema para las marcas. PRNoticias. Recuperado de https://prnoticias.com/comunicacion/clubagencias/canelapr/20167227-fake-news-problema-para-las-marcas\#inlineauto1611

Infonomia. (15 de marzo de 2012). «Infoxicación» entra en el Diccionario del español urgente. Infonomia. Recuperado de http://www.infonomia.com/infoxicacin-entra-en-eldiccionario-del-espaol-urgente/

Maglione, C., \& Varlotta, N. (s.f.). Investigación, gestión y búsqueda de información en internet. Conectarigualdad. Recuperado de http://www.isfd809esquel.com.ar/images/archivos/Investigaci onenInternet.pdf

Muñoz, P. (2017). Dipost digital dedocuments de la UAB. Recuperado de https://ddd.uab.cat/record/181870 
Pagán, F. (2007). El efecto mediático en la sociedad del conocimiento.

Comunicación y Pedagogía: Nuevas tecnologías y recursos didácticos. (218), 75.

Pérez, D. (19 de marzo de 2017). Anatomía de las noticias falsas: qué son y cómo están cambiando Internet. Omicrono. Recuperado de https://omicrono.elespanol.com/2017/03/anatomia-de-lasnoticias-falsas /

Queipo de Llano, C. (mayo de 2018). ¿Cuál es el rol del Dircom en la transformación digital? Innova + C. Recuperado de http://innova.dircom.org/opinion/comunicar-la-innovacionopinion/rol-del-dircom-la-transformacion-digital/

Ramos, J. (10 de mayo de 2017). Infoxicación. eprints.rclis.org. Recuperado de http:/ / eprints.rclis.org/32262/1/ensayo\%20infoxicacion.pdf

Rivera, D. (11 de abril de 2013). Top comunicación y relaciones públicas. Recuperado de http://www.topcomunicacion.com/noticia/3770/slowcomunicacion-contra-la-infoxicacion

Rodríguez, A. (s.f). En la era de la "infoxicación" qué cabida tienen las pequeñas empresas. IOMK Agencia de Marketing. Recuperado de https://www.iomarketing.es/blog/en-la-era-de-la-infoxicacionque-cabida-tienen-las-pequenas-empresas /

Romero, L., \& Mancinas, R. (2016). Sobresaturación informativa: visibilizar el mensaje institucional. En Comunicación institucional y cambio social. Claves para la comprensión de los factores relacionales de la comunicación estratégica y el nuevo ecosistema comunicacional. (pp.114-115). Sevilla, España: Ediciones Egregius.

Serrano, J. (2013). Una propuesta de dieta digital: repensando el consumo mediático en la era de la. Eusal Revista Gestor Digital (7), 164.

T13. (29 de junio de 2018). Falsas noticias en WhatsApp provocan ola de linchamientos en India. Recuperado el 30 de 10 de 2018, de http://www.t13.cl/noticia/mundo/falsas-noticias-whatsappprovocan-muerte-linchamiento-tres-personas-india

Urban diccionary. (s.f). Fake News. Recuperado de https://www.urbandictionary.com/define.php?term $=$ Fake $\% 20$ news 
Vidal, P. (diciembre de 2016). Infoxicación y gestión comunicacional tras el terremoto del 16 de abril de 2016 en Ecuador. ReserchGate. Recuperado de https://www.researchgate.net/publication/314043575_infoxica cion_y_gestion_comunicacional_tras_el_terremoto_del_16_de_ abril_de_2016_en_ecuador__infoxication_and_communication_management_after_the_ear thquake_ocurred_in_ecuador_on_april_16_2016

Villarroel, K. (2015). Infoxicación. Revista de Investigación Scientia, 4 (1). Vinarás, M. (2013). Estrategias de comunicación para generar confianza. Revista Comunicación y Hombre (9), 4. 



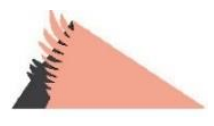 \\ Las autoras y los autores}

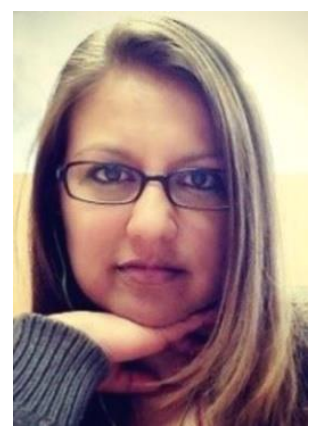

\section{PUERTAS-HIDALGO, ROSARIO}

Universidad Técnica Particular de Loja -

Ecuador

Máster en Comunicación e Industrias Creativas por la Universidad Santiago de Compostela-España.

Docente investigadora de la Universidad Técnica

Particular de Loja en Ecuador. Dentro de la misma Universidad, es

Docente en Pregrado: Titulaciones de Comunicación Social, de Relaciones Públicas. Parte del equipo de calidad y docente de la Maestría en Comunicación Estratégica mención Comunicación Digital. Parte del Grupo de Investigación Comunicación Estratégica. Google Académico: https://scholar.google.es/citations?hl=es\&user=PjKBbZUAAAAJ ORCID: https://orcid.org/0000-0002-9545-2223

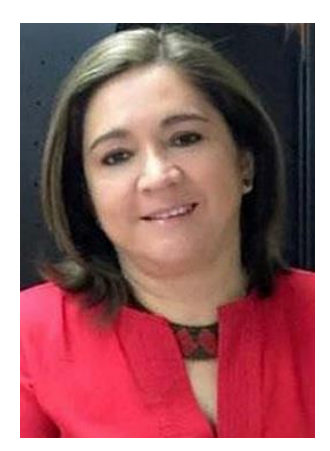

\section{ABENDAÑO, MÓNICA}

Universidad Técnica Particular de Loja - Ecuador Magíster en Dirección en Comunicación DirCom, por la Universidad San Antonio de Murcia, España. Es parte del Departamento de Ciencias de la Comunicación como Docente Investigadora en la línea de Comunicación Interna. Es co-creadora de

DialogusCI, la red virtual de comunicación interna en Iberoamérica y Directora Ejecutiva de la Asociación Ecuatoriana de Comunicación Interna-AECI.

Google Académico: https://scholar.google.com/citations?hl=es\&user=xLAUFr0AAAAJ ORCID: https://orcid.org/0000-0001-9549-8996 


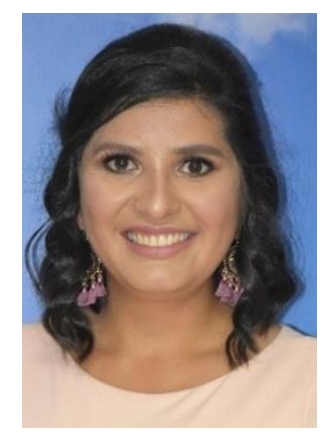

VALDIVIEZO-ABAD, CESIBEL

Universidad Técnica Particular de Loja -

Ecuador

Universidad Santiago de Compostela-España

Doctoranda en Comunicación e Información

Contemporánea en la Universidad de Santiago de

Compostela. Máster en Investigación de la

Comunicación en la Universidad de Navarra. Licenciada en

Comunicación Social. Profesora en el Departamento de Ciencias de la Comunicación y es parte del grupo de investigación Comunicación

Estratégica de la Universidad Técnica Particular de Loja.

Google Académico:

https://scholar.google.com/citations?hl=es\&user=KkJWSswAAAAJ

ORCID: orcid.org/0000-0003-4816-4752

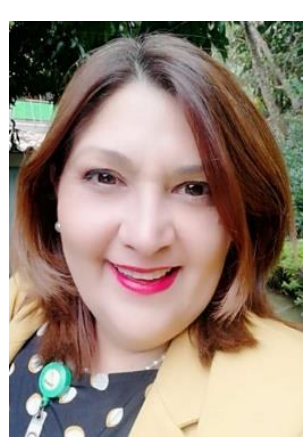

\section{RINCÓN QUINTERO, YANYN}

Tecnológico de Antioquia - Institución

\section{Universitaria}

Posdoctora en Derechos Humanos

Posdoctora en Gerencia de las Organizaciones

Doctora en Ciencias Gerenciales

M.Sc. en Administración de Empresas Turísticas.

Docente e Investigadora del Tecnológico de Antioquia - Institución

Universitaria. Investigadora Asociada Colciencias (2016-2019).

Miembro de Grupo de Investigación Research Enterprice Develoment.

Coordinadora de la Línea de Investigación Gestión y Estudios

Organizacionales. Miembro DialogusCI. Miembro Dircom.

Google Académico:

https:// scholar.google.com/citations?hl=es\&user=fI9pWd0AAAAJ

ORCID: https://orcid.org/0000-0003-2427-3161 


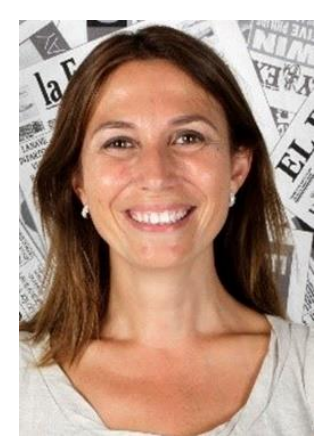

\section{COLL RUBIO, PATRICIA}

\section{Universitat Ramon Llull}

Doctora en Comunicación por Universidad Ramon

Llull (URL) es profesora colaboradora en la

Universitat Oberta de Catalunya y en la Escuela

Superior de Relaciones Públicas centro adscrito a la

Universidad de Barcelona. Colabora con El País Retina

y La V anguardia, entre otros medios de comunicación.

Google Académico:

https://scholar.google.es/citations?user=GmgT_1UAAAAJ\&hl=es

ORCID: https://orcid.org/0000-0001-7649-800X

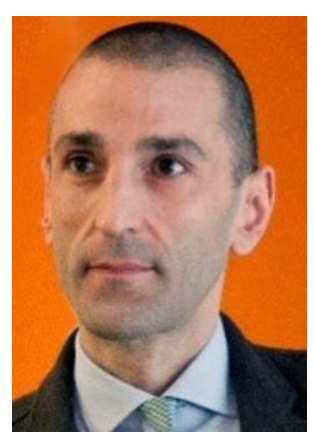

\section{LLUÍS MICÓ, JOSEP}

\section{Universitat Ramon Llull}

Catedrático de Periodismo de la Universitat

Ramon Llull (URL) y vicedecano de la Facultat de Comunicació i Relacions Internacionals

Blanquerna (URL), donde ha dirigido el Grado en Periodismo y másteres en reporterismo y

periodismo. Colabora con diversos medios, entre ellos La Vanguardia, Radio Nacional de España, NacióDigital y Diari de Girona.

Google Académico:

https://scholar.google.com/ citations?user=DbQOz-oAAAAJ

ORCID: https://orcid.org/0000-0003-1191-226X 


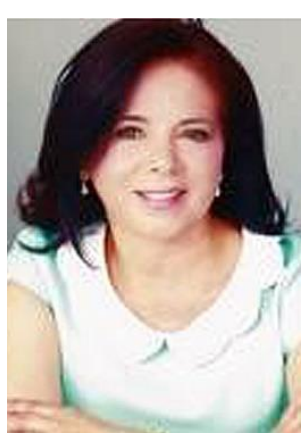

\section{ZAPATA PALACIOS, LELIA}

\section{Universidad Nebrija}

Profesora de Gestión de la Comunicación Interna en la Universidad Nebrija. Dra. por la Universidad Complutense de Madrid, Máster en Comunicación Formadora y Consultora en Talentos Reunidos.

Miembro de \#DialogusCI y de la Vocalía de Innovación en Dircom. Investiga sobre Innovación y cultura colaborativa.

Google Académico:

https:// scholar.google.es/citations?hl=es\&user=bKsNu4MAAAAJ ORCID: https://orcid.org/0000-0002-6543-7348

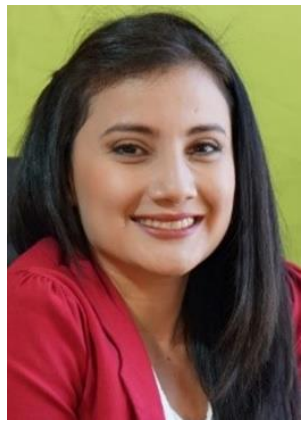

\section{SÁNCHEZ CALLE, LAURA}

Universidad Técnica Particular de Loja -Ecuador. Licenciada en Relaciones Públicas por la UTPL-Loja. Maestranda en Marketing y Comunicación DigitalEspaña Coordinadora de agencia de marketing y publicidad y Community Manager.

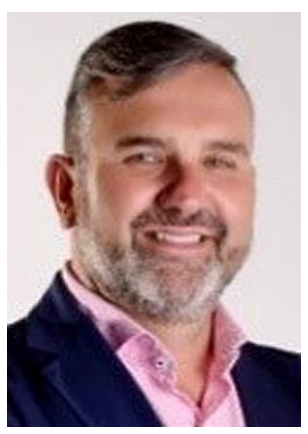

\section{CUSOT, GUSTAVO}

\section{Universidad San Francisco de Quito}

PhD. en Comunicación en la UNIACC. Vicedecano del Colegio de Comunicación y Artes Contemporáneas de la Universidad San Francisco de Quito. Coordinador de la carrera de Comunicación Organizacional de la Universidad San Francisco de Quito. Comunicador y asesor en el ámbito de la comunicación y la imagen corporativa de empresas e instituciones de Argentina, España, Estados Unidos y Ecuador. 
Google Académico:

https://scholar.google.com/citations?user=UN2GNpoAAAAJ\&hl= es

ORCID: https://orcid.org/0000-0002-8814-9808

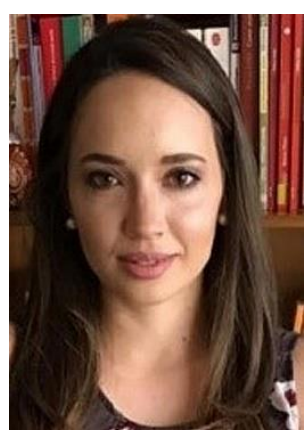

\section{PALACIOS, ISABEL}

Universidad San Francisco de Quito

Magister en Marketing Digital y Comercio

Electrónico, Licenciada en Comunicación

Organizacional y Relaciones Públicas. Profesora en línea de la Carrera de Comunicación Organizacional de la Universidad San Francisco de Quito. Consultora en comunicación y marketing digital.

Google Académico:

https:// scholar.google.es/citations?hl=es\&user=4lQpmw0AAAAJ

ORCID: https://orcid.org/0000-0002-0176-039X

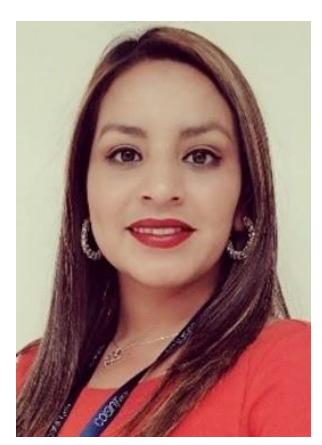

\section{DUQUE, VANESSA}

\section{Universidad Técnica Particular de Loja - Ecuador}

Universidad Santiago de Compostela - España

Docente de la Universidad Técnica Particular de Loja.

Doctoranda en Comunicación e Información

Contemporánea de la Universidad Santiago de

Compostela, Magíster en Dirección de Comunicación

Empresarial e Institucional y Licenciada en Ciencias de la

Comunicación Social. Trabaja e investiga en el ámbito de la comunicación corporativa.

Google Académico:

scholar.google.es/citations?user=Ai1_A9sAAAAJ\&hl=es

ORCID: orcid.org/0000-0003-0102-2829 


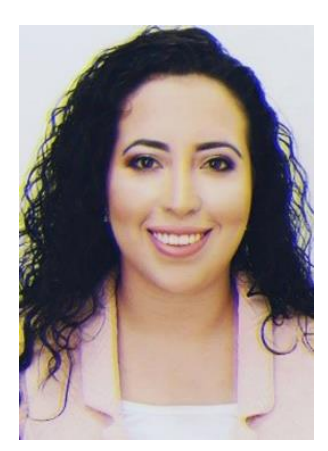

\section{ESPINOSA, ULIANOVA}

\section{Universidad Técnica Particular de Loja -}

Ecuador

Licenciada en Relaciones Públicas por la Universidad Técnica Particular de Loja. Estudia e investiga en el ámbito de la comunicación digital.

Google Académico:

https://scholar.google.es/citations?user=MlpyJOUAAAAJ\&hl=es ORCID: https://orcid.org/0000-0003-3473-1197

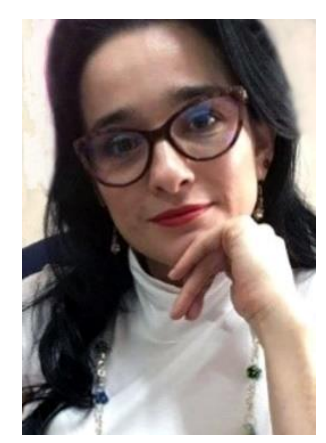

\section{VESGA HERNANDEZ, NANCY STELLA} Universidad Autónoma de Bucaramanga Colombia

Comunicadora Social - Organizacional. Especialista en Gestión Estratégica de Mercadeo UNAB, Especialista en Docencia Universitaria Universidad Industrial de Santander. Actualmente es docente de la Universidad Autónoma de Bucaramanga - UNAB. Es coach y asesora en temas de protocolo organizacional, oralidad, kinésica y mercadeo en diversas empresas Santandereanas.

Google Académico:

https://scholar.google.com/citations?hl=es\&user=3DqKjYgAAAAJ ORCID: https://orcid.org/0000-0002-3720-4002/print 


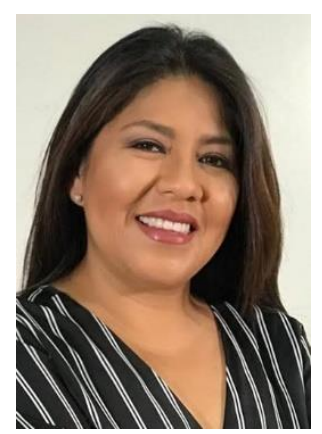

\section{JENNY YAGUACHE QUICHIMBO}

Universidad Técnica Particular de Loja - Ecuador

Ph.D. en Comunicación y Periodismo por la

Universidad Santiago de Compostela. Profesora del

Departamento de Ciencias de la Comunicación de la

Universidad Técnica Particular de Loja. Coordina el

Grupo de Investigación Comunicación Estratégica de

la misma universidad. Es parte de investigaciones internacionales

como el Latin America Monitor y Barómetro de la Gestión de la

Comunicación de Iberoamérica, lideradas por las universidades Rey Juan

Carlos y Santiago de Compostela de España.

Google Académico:

https://scholar.google.es/citations?hl=es\&user=7Uwl0pcAAAAJ

ORCID: https://orcid.org/0000-0002-5489-4228

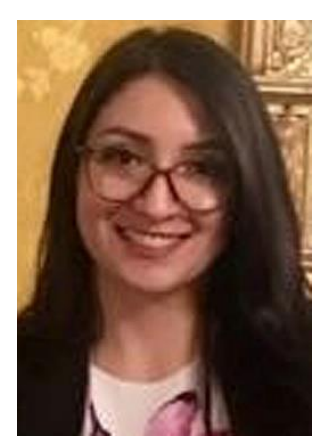

\section{STEFANI PALADINES CARRANZA}

Universidad Técnica Particular de Loja - Ecuador

Licenciada en Relaciones Públicas por la Universidad

Técnica Particular de Loja. Ha sido ejecutiva de cuentas en agencias de comunicación en Loja. Fue parte del proyecto 'Colmena Digital' desarrollado en la UTPL. 